Illinois State University

ISU ReD: Research and eData

Theses and Dissertations

3-29-2021

\title{
Ordinary Power: Frontier Sentimentalism And Cultural Perceptions Of Gender In The Nineteenth-Century West
}

\author{
Erin Elizabeth Hastings \\ Illinois State University, eehasti@ilstu.edu
}

Follow this and additional works at: https://ir.library.illinoisstate.edu/etd

Part of the United States History Commons

\section{Recommended Citation}

Hastings, Erin Elizabeth, "Ordinary Power: Frontier Sentimentalism And Cultural Perceptions Of Gender In The Nineteenth-Century West" (2021). Theses and Dissertations. 1373.

https://ir.library.illinoisstate.edu/etd/1373

This Thesis is brought to you for free and open access by ISU ReD: Research and eData. It has been accepted for inclusion in Theses and Dissertations by an authorized administrator of ISU ReD: Research and eData. For more information, please contact ISUReD@ilstu.edu. 


\section{ORDINARY POWER: FRONTIER SENTIMENTALISM AND CULTURAL PERCEPTIONS OF GENDER IN THE NINETEENTH-CENTURY WEST}

\section{ERIN E. HASTINGS}

\section{Pages}

This thesis will examine nineteenth-century women and their primary role in the cultural formation of frontier sentimentalism. White, middle class women primarily moved west with their husbands and families, initially to the Midwest in the early nineteenth century, and were continuing to settle in the Great Plains and further west by the end of the century. The first generation of women who migrated west were the pioneers of frontier sentimentalism, but it prevailed in successive generations of westering women. This thesis will argue that in the formation of their own form of sentimentalism, nineteenth-century women were at the heart of a new cultural phenomenon that not only shaped their lives and experiences in the West but was instrumental in the crafting of an American myth. Women along the eastern seaboard like Lydia Maria Child began producing sentimental novels that enshrined pastoral republican virtues in a field of American literature dominated by women. Expected to disseminate society's moral standards, women encouraged Americans to follow all these virtues, associating them with a patriotic citizenry. Women who migrated West carried these values with them, and by midcentury they were living the experience that became the frontier sentimental. The American frontier became idealized as the epitome of the nation's identity and mythos by the end of the century, and women were doing the cultural work of mythmaking.

KEYWORDS: Frontier, Sentimentalism, Women, $19^{\text {th }}$-century, Gender 
ORDINARY POWER: FRONTIER SENTIMENTALISM AND CULTURAL PERCEPTIONS

OF GENDER IN THE NINETEENTH-CENTURY WEST

ERIN E. HASTINGS

A Thesis Submitted in Partial
Fulfillment of the Requirements
for the Degree of
MASTER OF SCIENCE
Department of History
ILLINOIS STATE UNIVERSITY

2021 
(C) 2021 Erin Hastings 


\section{ORDINARY POWER: FRONTIER SENTIMENTALISM AND CULTURAL PERCEPTIONS OF GENDER IN THE NINETEENTH-CENTURY WEST}

ERIN E. HASTINGS

COMMITTEE MEMBERS:

Amy Wood, Chair

Linda Clemmons 


\section{ACKNOWLEDGMENTS}

I jumped into grad school in August of 2019, knowing from the start I wanted to write a thesis, prepared for the challenges it would throw my way. I, like most, however, was not anticipating the extra challenge of writing my thesis during the global crisis of a pandemic. Despite multiple colleagues and peers telling me among the developments of 2020 that I did not have to do a thesis, they would understand if I changed tracks, I still felt a dedication to this project, and the women at the heart of it. When I told my peers this, I was still met with unwavering support and people who genuinely believed that I could succeed at this project despite the circumstances. With that, I was reminded once again of one of the most important lessons I have learned throughout my life: that no one achieves anything alone. Since it would be contradictory to not be my truest sentimental self, I have many people I would like to thank.

First and foremost, I would like to thank my committee members, Dr. Amy Wood and Dr. Linda Clemmons for embarking on my largest academic journey to date, and for being as invested in this project as I am. It has been an immense privilege to work with two brilliant scholars and women whom I admire greatly. To Dr. Clemmons, the passion, integrity, and sheer intelligence you bring to all your work inspires me in all my endeavors. You have been with this project since the very beginning, and as always, both me and this project have benefitted greatly from your bright perspective. To Dr. Wood, it feels quite fitting that you have been an integral part of this project as well, as you have been a key part of my academic journey. From my days as a timid and unsure undergrad, you have fostered me under your tutelage and helped me grow immensely as a writer, academic, and individual. I have learned countless things from you, and for that I cannot thank you enough. Although you would likely say it was a mutually beneficial 
experience because you now have a much greater knowledge of memes, the years I have spent working with you are ones I will always cherish. Since I have spent my undergraduate and graduate career at Illinois State University, I have had the pleasure of making many more connections within the history department. I would also like to thank Drs. John Reda, Kyle Ciani, Andrew Hartman, and Alan Lessoff who have helped me fully discover my passion for history, develop and confidently use my voice, pushed me out of my comfort zone and encouraged me to become a better writer, scholar, and person.

To my dear friends: Tara, Elliot, Sarah, Abby, Tim, Kelly, Cassie, Stephanie, Amanda, Taylor, Matt, Emi, Andrew, Becca, Tabitha, Darcy, and Luke, I could not have made it to this point without you, and you all have helped me grow in many ways. Much like the women in my study, I learned how vital support systems are, and you all have genuinely supported me and kept me going when I thought I couldn't anymore. To Erin Barr especially, the other half of our iconic Erin squared duo, I would not have even considered this path without you.

Last but certainly not least, I would like to thank my family. Thank you to my parents especially, as your constant support has always meant the world to me. Words cannot express how grateful I am for all you have done for me and that you have always allowed me to forge my own path in this world. To my sister, Sarah, who has always supported me and fostered a love of literature from a young age. I could not have done this if I didn't really love to read. Of course, to my beloved cat, Mellie, for being my best pal since 2004. Thank you to my dear grandparents, who I am so fortunate to know. Not only are you absolute treasures, but it is because of you that I have the privilege of knowing my own history.

E.E.H. 


\section{CONTENTS}

Page

ACKNOWLEDGMENTS

FIGURES

CHAPTER I: INTRODUCTION: SENTIMENTAL FRONTIERS 1

CHAPTER II: FICTIONAL FOUNDATIONS: WOMEN'S SENTIMENTAL FICTION AND

NATIONAL MYTH

CHAPTER III: A CURE FOR CORRUPTION: FRONTIER VIRTUE AND WOMEN'S

$\begin{array}{ll}\text { ADVICE LITERATURE } & 51\end{array}$

CHAPTER IV: LIVING THE IDEAL: FRONTIERSWOMEN MAKE FRONTIER

SENTIMENTALISM THEIR REALITY 76

CHAPTER V: CONCLUSION: LASTING LEGACIES: LAURA INGALLS WILDER AND

$\begin{array}{ll}\text { FRONTIER NOSTALGIA } & 105\end{array}$

$\begin{array}{ll}\text { REFERENCES } & 113\end{array}$ 


\section{FIGURES}

Figure $\quad$ Page

1. London's Latest Fashions-Caps and Bonnets, c. 1831. LA Godey \& Co. 56

2. The Queens of Europe, c. 1836. LA Godey \& Co. 57

3. Philadelphia Fashions, c. 1833. LA Godey \& Co. 59 


\section{CHAPTER I: INTRODUCTION: SENTIMENTAL FRONTIERS}

Some historians are fortunate enough to have a project-defining moment fall into their lap; in the fall of 2019, I had one of them. The first semester of my master's degree program, I took a seminar on the history of antebellum America, where I became interested in nineteenthcentury frontierswomen. In my search for primary sources, I was directed to a diary penned by an anonymous woman living in the Peoria, Illinois area from 1858-1859 by our university's rare book librarian. While some might have found the account of her ordinary day-to-day life menial, I saw incredible value. This anonymous woman, obscured by history, served as the starting point for my thesis as I read the accounts of her life and thought "why are women like her not a bigger part of the conversation surrounding the frontier?" This woman's accounts told the story of someone who worked hard on her farm with her husband, valued her work, and was valued in return by her family and community. At the same time, she did not threaten traditional notions of nineteenth-century womanhood - in fact, she still embraced them while making room for this hardworking ideal. As I read the writings of other frontierswomen, I noticed them using similar language of sentimentalism as the Peoria woman to frame their experience. It was then that I wondered if these women were creating a new ideal to uphold as they navigated nineteenthcentury transformations, and what impact that had. I came to conceive of this ideal as "frontier sentimentalism." The frontier sentimental formed a distinct American identity that characterized by the western frontier: it idealized the simpler, agrarian, self-sufficient, hardworking virtues of the region and became the quintessential American image.

Since the aftermath of the Revolution, Americans emphatically sought to differentiate themselves from the oppressive aristocracy of Europe they had just earned their freedom from through republicanism, an ideology that first emerged in the eighteenth century. American 
republicanism, which valued simplicity, genteel self-regulation, and industrious self-sufficiency over aristocratic ostentation helped to create a distinct national identity rooted in a virtuous American character. By the 1830s, however, the rise of urban centers and market capitalism in the northeast caused fears that the country's distinctive republican virtue was eroding.

Sentimentalism emerged as a dominant cultural value system in the nineteenth century, and it became important in reconciling the new urban market culture to republican ideals. Sentimentalism used intense feeling for others as the basis for virtue. It governed social norms and behaviors and found its fullest expression in middle-class literature. In the immediate aftermath of the Revolution in the late eighteenth century, America's image of simpler virtue was attributed to the sentimental "Man of Feeling"- -his genuine, patriotic sacrifice of selfinterest for the good of the republic kept the nation afloat. As urbanization and market capitalism began to transform the American landscape, however, American masculinity became more assertive and associated with brave military valor. It was women, then, who were now a repository for sentimental culture. As historian Andrew Burstein points out, American women were now seen as possessing "more gentleness, more softened amiableness than men possess ... more sensibility, more influence upon the heart." ${ }^{\text {B }}$ By the nineteenth century, sentimentalism had largely become the province of women; sentimentalism eased middle-class anxieties about the corrupting nature of capitalist markets and new urban environments, largely through women's roles in the domestic sphere, which existed separately from the world of business and politics. Separate spheres, as it was known, put women at the heart of sentimental culture, upholding virtue and gentility in the home. If men were going into the public sphere and engaging in

\footnotetext{
${ }^{1}$ Andrew Burstein, Sentimental Democracy: The Evolution of America's Romantic Self-Image (New York: Hill and Wang, 1999), 311.
} 
capitalist practices that could corrupt one's soul, they came home to women who, through naturally promoting and embodying sentimental ideals, preserved public virtue through private means. In sentimental culture, women were thus heralded as the preservers of republican virtue and purity. Through the "cult of true womanhood," primarily white, upper and middle-class women were sentimentalized as being innately more moral, virtuous, and thus closer to God than men. Popular sentimental literature, such as Harriet Beecher Stowe's Uncle Tom's Cabin, exalted women as central to a morally upstanding society.

Early nineteenth-century Americans not only divided space into virtuous private spheres and tainted public ones, but they divided geography, the city from the country, similarly, through what was known as the pastoral ideal. The pastoral ideal sentimentalized rural America and represented it as a separate sphere from the corruption of industry and chaotic urban life in the East. This ideal was implemented into sentimental literature to escape urban industrialization. Sentimentalism had proven a highly adaptable tool for propelling culture forward, and many Americans amidst the changes of the nineteenth century came to identify with an idealized pastoral landscape in places like rural Massachusetts and other rural eastern frontiers and the supposedly simple virtues associated with it. The pastoral virtues of self-sufficiency, frugality, hard work, and resilience became the ideal American cultural standard. The pastoral ideal, then, became another form of "separate spheres" in the nineteenth century, distinguishing between corruptible urban centers and idyllic rural areas where republican virtues were sentimentalized.

The courageous pioneers who braved the journey West, from the eastern seaboard across the Appalachian Mountains, carried these virtues with them as they formed new settlements and communities. In this way, as the nation expanded westward in the antebellum era, the pastoral ideal was transferred to the American frontier, which came to be imagined as a repository for 
republican virtue and simplicity. The frontier was imagined in this way by Americans along the eastern seaboard who were becoming increasingly uncomfortable with urbanization. This new form of sentimentalism associated with the frontier - what I am terming frontier sentimentalism - served as a form of literary escapism from the intense transformations of the nineteenth century. In sentimental fiction, frontier sentimentalism exalted the moral triumphs of those who adhered to simpler, self-sufficient ideals, and applied more capable, hardworking and courageous ideals to traditional definitions of womanhood as well. And advice literature for women reminded them it was patriotic to embrace the rural ideal through fashion or through how they kept their homes. Women along the eastern seaboard like Lydia Maria Child began producing sentimental novels that enshrined pastoral republican virtues in a field of American literature dominated by women. Expected to disseminate society's moral standards, women encouraged Americans to follow all these virtues, associating them with a patriotic citizenry. Women who migrated West carried these values with them, and by mid-century they were living the experience that would become the frontier sentimental.

The women who migrated west were themselves immersed in frontier sentimentalism and were brought to this new setting as pillars of morality, whose role it was to "civilize" the western wilderness. In their new western homes, women attempted to hold on to notions of both true womanhood and American "civilization," by creating respectable homes and raising respectable families who would contribute to and expand the virtuous citizenry of the nation. They soon found their roles shifting, however, as they were depended upon for survival. While pioneer women were responsible for preserving American culture through the traditional private sphere, the frontier blurred separate spheres as women had to assist their husbands on frontier farms in what were traditionally masculine roles. Many women became economic helpmates of their 
husbands and formed marriages that were more cooperative in nature. Frontier women were also looked to as the basis of community strength and were responsible for maintaining social networks. This lofty cultural role allowed them to make the frontier sentimental a lived reality as they structured their lives around this ideal, which still exalted women as moral beings, wives, and mothers, but also valued them as capable and strong and exalted courage as a core feminine value.

This study will focus on nineteenth-century women and their primary role in the cultural formation of frontier sentimentalism. White, middle class women primarily moved west with their husbands and families, initially to the Midwest in the early nineteenth century, and were continuing to settle in the Great Plains and further west by the end of the century. The first generation of women who migrated west were the pioneers of frontier sentimentalism, but it prevailed in successive generations of westering women. I argue that in the formation of their own form of sentimentalism, nineteenth-century women were at the heart of a new cultural phenomenon that not only shaped their lives, self-perceptions, and experiences in the West, but was instrumental in the crafting of an American myth. The American frontier became idealized as the epitome of the nation's identity and mythos by the end of the century, and women were doing the cultural work of mythmaking.

The American frontier still captures our national imagination in the present, and many historians have grappled with its impact, contributing to an incredibly vast historiography. The mythology and study of the American frontier can be traced back to Frederick Jackson Turner's famous 1890 "Frontier Thesis." Turner's writing attributes the unique republican character of America to the frontier: 
To the frontier, the American intellect owes its striking characteristics. The coarseness and strength combined with acuteness and inquisitiveness, that practical, inventive turn of mind, quick to find its expedients, that masterful grasp of material things, lacking in the artistic but powerful to effect great ends, that restless, nervous energy, that dominant individualism, working for good and for evil, and withal that buoyancy and exuberance which comes with freedom-these are the traits of the frontier, or traits called out elsewhere because of the existence of the frontier. ${ }^{2}$

Turner's "Frontier Thesis" is significant because it was pivotal to popular American ideas about the frontier, though, to be sure, he has garnered many critics since the rise of social history in the 1970s and 1980s. However, no matter how warranted criticisms of Turner may be for modern historians, it is important to note that he was reflecting ideas about the frontier that dominated the larger American culture at the time. The "Frontier Thesis," as Greg Grandin points out, "argued that expansion across a frontier of 'free land' created a uniquely American form of political equality, a vibrant, forward-looking individualism-placed wager on the future."3 The frontier and freedoms associated with it was America's essence and its future. Turner was doing this work, however, without acknowledging women and the key role they played in cultural imagery about the West. Turner often receives credit for this ideal and cementing it in the American conscious, yet he was articulating an American myth that women had been weaving for most of the century.

Certainly, Turner's approach leaves much to be desired. As Paula Nelson has pointed out, his sole focus on masculinity and political and economic development stifled important voices in

\footnotetext{
${ }^{2}$ Frederick Jackson Turner, "The Frontier in American History," Rev. ed. Tucson: University of Arizona Press, 1994. Print, In Danver, Steven L. “"The Significance of the Frontier in American History," Defining Documents in American History: The Emergence of Modern America (1874-1917). Hackensack: Salem, 2014, Accessed August 25, 2020.

${ }^{3}$ Greg Grandin, The End of the Myth: From the Frontier to the Border Wall in the Mind of America (New York: Metropolitan Books, 2019), 1.
} 
frontier cultural history, importantly, Native Americans, but also white women. ${ }^{4}$ Historians such as John Mack Faragher and Glenda Riley pioneered the inclusion of frontier women into the historiography by examining women's roles in the West and their places in their communities, showing that women on the frontier expanded the boundaries of nineteenth-century womanhood without threatening traditional notions of it. ${ }^{5}$

As frontier historiography has evolved to include women, the source base has become richer with the addition of new voices. Frontier women's diaries, letters, and memoirs have gained validity as primary sources. As Gayle Davis asserts, "Contrary to the pervasive stereotype of male heroism and female passivity that has clouded our historical perspective on frontier life, the diaries reveal women's varied responses to the West - their many attempts to conform to Victorian traditions on the frontier and their many personal rebellions." "A glimpse into the private reflections and authentic voices of frontier women provides more depth to the historical narrative of frontier life and counters the belief that these women were passive and onedimensional.

While historians have examined women's experiences on the frontier and their importance as actors, they have not fully examined their involvement within the larger cultural context of Victorian America. In order to fully understand women's crucial historical relevance to the formation of the frontier, one must understand the nineteenth-century cultural milieu that dictated American social norms. Sentimentalism was central in women's lives and did not simply

\footnotetext{
${ }^{4}$ Nelson, Paula M. "The Significance of the Frontier in American Historiography: A Review Essay." Annals of Iowa 50, no.5 (1990): 531-40.

${ }^{5}$ Faragher, John Mack. Sugar Creek: Life on the Illinois Prairie. Yale University Press, 1986; Riley, Glenda. The Female Frontier: A Comparative View of Women on the Prairie and the Plains. University Press of Kansas, 1988. ${ }^{6}$ Davis, Gayle R. “Women's Frontier Diaries: Writing for Good Reason.” Women's Studies 14, no. 1 (1987): 5.
} 
fade when they migrated to the frontier; its power and dominance in governing white middleclass culture migrated with westering women.

Historians who have focused on nineteenth century sentimental culture, however, have primarily focused on the northeastern seaboard and developing urban centers. Indeed, this focus has been an important one, as the heart of sentimental culture was developed along the east coast. Nancy Cott, among the first to write about the "cult of true womanhood" and separate spheres, acknowledged the importance of family sentiment that was at the heart of sentimental culture, as it provided the social control necessary to uphold republican values in a democratic republic. For nineteenth century women, republican motherhood and domestic power in the private sphere was their cultural leverage through which they could extend said power to the public world. Ann Douglas, on the other hand, has criticized sentimental culture for valuing feeling over intelligence, and giving middle class women influence rather than power. ${ }^{7}$ Douglas's dismissal of sentimentalism, however, has been refuted for its lack of insight into historical and cultural context, most notoriously by scholar Jane Tompkins. ${ }^{8}$

Both Douglas and Cott, however, represent nineteenth-century sentimentalism as sharply removed from the public sphere. Elizabeth White Nelson, more recently, has shown that these divisions were not so rigid. The rise of nineteenth century capitalist consumer culture was bolstered by sentimentalism at the same time as sentimentalism was seen as a remedy for capitalist greed, a dynamic Nelson terms "sentimental pragmatism," in that its justification of capitalist culture allowed women access to the public realm. Those rising through class ranks

\footnotetext{
${ }^{7}$ Cott, Nancy F. The Bonds of Womanhood: “Woman's Sphere” in New England, 1780-1835. Yale University Press, 1977; Douglas, Ann. The Feminization of American Culture. New York: Farrar, Straus, and Giroux, 1998.

${ }^{8}$ Tompkins, Jane. Sensational Designs: The Cultural Work of American Fiction, 1790-1860. New York: Oxford University Press, 1985.
} 
embraced sentimental rhetoric surrounding Christian, republican ideals to justify their mobility into the middle class. In other words, white middle-class Americans embraced sentimentalism in the public realm, by using the language of emotion and virtue to achieve capitalist economic ends and shift any suspicion away from the potential greed and corruption of capitalist consumer activities. $^{9}$

Historians such as Karen Halttunen have similarly acknowledged the co-optation of sentimentalism into capitalism through the world of social etiquette and fashion, which thoroughly defined middle-class culture. Because women's innate sincerity was the natural counter to the corruption of the public sphere, women were primarily responsible for showing their truest, virtuous, most sentimental selves through their social behavior and through fashion. Fashion should highlight their natural beauty and simplicity, for any excessive ornamentation that would display wealth and hide one's true self was deemed hypocritical and counter to sentimental republican virtue. ${ }^{10}$

While most historians have focused on the importance of sentimentalism to the white, middle classes, recent historians have questioned the degree to which other social groups adopted sentimentalism as a cultural ideal. For example, while sentimental language and culture was highly racialized, that did not stop some literate slaves from utilizing it for their own means. As slaves were ripped from their families and sold into the slave market, sentimentalism, as Phillip Troutman points out, was a tool for slaves to reach their families through letters and bridge any

\footnotetext{
${ }^{9}$ Nelson, Elizabeth White. Market Sentiments: Middle-Class Culture in Nineteenth Century America. Washington, D.C.: Smithsonian Books, 2004.

${ }^{10}$ Halttunen, Karen. Confidence Men and Painted Women: A Study of Middle-Class Culture in America, 1830-1870. Yale University Press, 1982.
} 
physical gap when separated. ${ }^{11}$ Studies like Troutman's that expand the scope of sentimentalism are of great importance to understanding its cultural impact; this project also seeks to expand the study of sentimentalism by focusing on its dissemination beyond the northeast to the western frontier.

This study will answer the question of how women formed what became the frontier sentimental, structured their lives around it, and how it became characteristic of American identity by the late nineteenth century. This project will use women's sentimental fiction, domestic advice literature, publications such as Godey's Lady's Book, and frontier women's letters, diaries, memoirs to showcase how Eastern women utilized the pastoral ideal to craft a distinct American identity that upheld republican virtue, later being translated into the West by frontierswomen and became frontier sentimentalism.

Frontier sentimentalism was initially projected onto rural environments through the eastern pastoral ideal, so the first two chapters focus on early production of the rural, pastoral ideal along the eastern seaboard. The first chapter examines early national cultural production of sentimentalism and show how the core values of frontier sentimentalism were appearing in sentimental literature in the East. Early sentimental writers of domestic fiction from the 1820 s to the 1840s like Catharine Maria Sedgwick and Lydia Maria Child wrote women as strong, courageous, and capable while upholding republican virtue that challenged sentimentalized notions of dependent and demure womanhood. Opposing the notion that women's sentimental fiction is "trivial" and "insignificant" literature, this chapter challenges women's exclusion from

\footnotetext{
${ }^{11}$ Troutman, Phillip. Correspondences in Black and White: Sentiment and the Slave Market Revolution. In Baptist, Edward. E. and Camp, Stephanie, eds. New Studies in the History of American Slavery. Athens: The University of Georgia Press, 2006.
} 
the realm of significant literature and posits that women were vital actors in the formation of a distinctly American identity through adaptation of sentimental frontier qualities in their writings.

The second chapter moves from the realm of sentimental fiction to show how women applied the frontier sentimental to the real world, as they encouraged others to follow it through advice literature. The urban world of fashion and frivolity threatened to undermine republican virtue, so popular magazines like Godey's urged fashionable women of the East to be more like their sisters in rural areas. Domestic advice manuals such as Lydia Maria Child's The American Frugal Housewife encouraged frugality, industry, self-sufficiency, and resilience - qualities attributed to rural women and later frontierswomen as the nation expanded westward. The frontier became the focal point of republican virtues, and it became the sentimental ideal of what it meant to be American; even women in the East sought out this ideal, and-because it was their duty to prescribe society's moral standards - encouraged others to do the same.

The third chapter will examine frontierswomen's lived experiences as the moved West and how they structured their experience around the sentimental pastoral ideal that was being expanded out to the frontier. While some women were migrating earlier in the 1830 s, by the midnineteenth century westering women were defining their experience by frontier sentimentalism as it became more embedded in the landscape. In this new setting, women such as Rebecca Burlend felt the weight of their new roles, and framed attaining the pastoral, frontier ideal as a duty. Communities of women on the frontier supported each other in their new setting and helped each other attain this new ideal of womanhood. These women and their support networks were still interested in cultivating good taste, and they brought gentility to western towns; yet they tailored it to the idealized pastoral setting and republican virtue, finding that good taste could be cultivated even in the rural backwoods and could be attained by anyone with hard work 
and frugality. These women ended up solidifying what became the American mythos emerging from the frontier because they lived this ideal and filtered their experiences through it.

Women were at the heart of cultural formation in the frontier setting, and they created their own form of sentimental culture that remains today in American cultural interpretations of the frontier. The frontier expanded the United States culturally as well as geographically Women were a key part of this cultural expansion, and sentimentalism was a key component; it is a narrative that deserves attention. 


\section{CHAPTER II: FICTIONAL FOUNDATIONS: WOMEN'S SENTIMENTAL FICTION AND}

\section{NATIONAL MYTH}

This chapter discusses the foundation of women's sentimental fiction by women writing along the eastern seaboard in the early nineteenth century, which women emigrating to the frontier would later take with them. Sentimentalism was so pervasive in nineteenth century America that it governed cultural norms, codes of behavior, and fashion trends. Sentimental fiction as well was crucial in the creation of an American identity. In the post-Revolutionary world of the nineteenth century, Americans were trying to be just that-American. This meant distinguishing themselves from their European roots to create an independent national identity. Sentimental fiction — and the women behind the genre — were key in cementing these values into the national consciousness.

National mythologies, as Richard Slotkin asserts, are "embodied in literature," and can be seen as an "intellectual or artistic construct that bridges the gap between the world of the mind and the world of affairs, between dream and reality, between impulse or desire and action. It draws on the content of individual and collective memory, structures it, and develops from it imperatives for belief and action." 12 In this sense, the production of sentimental literature that emphasized and promoted republican virtues by associating them with the frontier helped cement a distinctly American national ethos.

Slotkin's work provides more insight into why republican rural- and frontier- virtues were so present in American sentimental literature. As Slotkin points out, in order to be believable as distinctly American, "literary characters had to be rooted in the wilderness soil,

\footnotetext{
${ }^{12}$ Richard Slotkin, Regeneration Through Violence: The Mythology of the American Frontier, 1600-1860 (Norman: University of Oklahoma Press, 1973), 3-7.
} 
rather than among the refinements of European civilization, and their admirable qualities would have to reflect the virtue of American soil." 13 Thus, in the search for a national identity, nineteenth-century Americans clung to the rural virtues that characterized their earliest days as a nation. With this they tied their nation's character to the rural landscape. As the geographical boundaries expanded, the frontier became the heart of the American mythos, even as - and because - cities in the east expanded and industrial capitalism developed. The self-sufficient, industrious, and republican farmer or frontiersman became the quintessential American in the popular imagination.

Slotkin's work, while extensive and an important formative tool for examining how literature can structure a collective reality, is missing a key component: women. He examines how prominent literary works by authors such as Nathanial Hawthorne, Herman Melville, and Henry David Thoreau established an American identity while making only brief mention of popular women writers Lydia Maria Child and Catherine Sedgwick. ${ }^{14}$ He thus presents the nineteenth-century literary process of American identity formation as a primarily male one. Women were not only also on the literary scene, however, but some like Sedgwick and Child became household names, and their books outsold those in the literary canon like Hawthorne. Child especially was popular in the literary world - Sedgwick was noteworthy, but Child caused more of a stir with radical challenges to patriarchy and racism throughout her career as an activist. Well-known Transcendentalists took note of her. As Michaela Keck acknowledges, Child's novel Philothea was not only received favorably by male Transcendentalist circles, but influenced them as well, as "Henry David Thoreau, for example, copied numerous quotes and

\footnotetext{
${ }^{13}$ Slotkin, Regeneration Through Violence, 321.

${ }^{14}$ See Slotkin, Regeneration Through Violence, 451.
} 
passages, particularly those relating to Child's fictitious Plato." ${ }^{15}$ The nineteenth century literary world was one in which women's presence could not be ignored - they were far from being marginal.

Sentimental literature was domestic-centered fiction that commented on different aspects of society by seeking an emotional response from readers. Their books have been dismissed due to their maudlin qualities, the moral lessons and cliché tropes attached to them; yet this genre of literature was a vital tool of cultural formation in early nineteenth-century America, yet even in the present, the women who produced it do not receive their due credit. Even after the emergence of women's history and cultural history in the 1970s and 1980s, sentimental literature and the women producing it have been typically regarded as "trivial" and pushed to the sidelines, viewed as unworthy of recognition. The exclusion of women from the American literary canon, as literary scholar Jane Tompkins points out, has been incredibly problematic because it ignores a whole group of women who were not only key actors in producing an American cultural framework, but were expected to disseminate standards for the society they lived in. Twentieth century scholarship on sentimental literature perpetuated this trend by continuing to relegate these women as literary figures of little significance. Specifically arguing against scholars such as Ann Douglass, Tompkins asserts that "while it has recently become fashionable to study their works as examples of cultural deformation, even critics who have invested their professional careers in that study and who declare themselves feminists still refer to their novels as trash."16

\footnotetext{
${ }^{15}$ Michaela Keck, "Deliberately Out of Bounds: Women's Work on Classical Myth in Nineteenth-Century American Fiction." (Heidelberg: Universitätsverlag Winter, 2017), 115. ProQuest Ebook Central - Reader. ${ }^{16}$ Jane Tompkins, Sensational Designs: The Cultural Work of American Fiction, 1790-1860 (Oxford University Press: 1985), 123.
} 
Part of why scholars have dismissed sentimental fiction has to do with its emotional component. Emotion is often regarded as the very antithesis of intelligence, and as Tompkins highlights, "twentieth-century critics have taught generations of students to equate popularity with debasement, emotionality with ineffectiveness, religiosity with debasement, domesticity with triviality, and of all of these, implicitly, with womanly inferiority." Scholarly criticism of sentimental literature has done a disservice to women, as they are often labeled as "manipulators of a gullible public who kept their readers imprisoned in a dream world of self-justifying cliches. Their fight against the evils of their society was a fixed match from the start."17

Additionally, scholars have deemed this literature inferior without considering the everimportant historical context. In the sentimental world of the early nineteenth century, the language of emotion was universal; women were tasked with prescribing moral standards for American society during this time used this language to make appeals for social improvement because it was already widely accepted and used. Considering that women were elevated as harbingers of American morality, the only acceptable means for them to disseminate moral standards for society was within this context of emotional appeals to virtue. Women producing sentimental literature could only work within the constraints they were given; adhering to their gendered roles was the only way they could gain entry into the male-dominated literary worldthey had to be strategic.

When context is considered, these women were not anti-intellectual manipulators of society, but intelligent women looking to comment on their society and order their reality through the only avenues provided to them. Harriet Beecher Stowe's Uncle Tom's Cabin, for

\footnotetext{
${ }^{17}$ Tompkins, Sensational Designs, 123-124.
} 
instance, was the most popular piece of sentimental fiction in the first half of the nineteenth century. Even today, Stowe's work is credited with galvanizing abolition movement in the United States. If sentimental fiction was so trivial and insignificant, what explains this success? Stowe, like other women writing sentimental fiction, knew her audience, and as Tompkins points out, was able to "combine so many of the culture's central concerns in a narrative that is immediately accessible to the general population that she is able to move so many people so deeply." ${ }^{18}$ Like Stowe, Child, as this chapter will examine, also used sentimental appeals in her novels to move society toward moral improvement.

The disregard of sentimental fiction has also ignored a rich literature base that was instrumental in the formation of American national identity rooted in rural republicanism. Since the corruption of the urban capitalist public sphere was associated with masculinity, it primarily fell on women to counteract it. Thus, using the only acceptable genre of literature available to them, women became cultural producers of a new, virtuous American character. In doing so, they created a sub-genre of sentimental fiction: that I term frontier sentimentalism. This new subset of sentimentalism emphasized the tenets of self-sufficiency, resilience, industry or hard work, and associated these qualities with national progress and the expansion of American "civilization;" anyone wishing to identify themselves as American during this time sought to emulate this new sentimental ideal.

Frontier sentimentalism drew from early nineteenth-century romanticism and pastoralism, genres that were themselves tied to America's patriotic roots. According to Anne C. Rose, romanticism, "celebrated nature's untamed free spirit. The vision of pastoralism, in

\footnotetext{
${ }^{18}$ Tompkins, Sensational Designs, 135.
} 
contrast, focused on the image of the cultivated garden, where the best impulses of civilization tailored nature's gifts for human ends." ${ }^{19}$ Both of these visions, though contrasting, went hand in hand, as romanticism admired and appreciated nature's bounty and pastoralism—especially as the frontier expanded - celebrated the taming of nature and spread of American "civilization." Thus, frontier sentimentalism had such cultural resonance because it resolved on paper the contradictions of a developing urban capitalist world. The tenets of frontier sentimentalism preserved the nation's virtuous republican image in a sentimental literary world (largely dominated by white women) at a time when urban capitalism threatened to corrupt it.

Ideas about the western frontier were rooted in literary representations of the rural countryside in the East. The pastoral ideal, which later translated into frontier sentimentalism, was initially used to exalt the merits of rural farmers. Some east coast residents imagined the rural backwoods as an uncivilized region of dirty farmers and their wives oppressed by their labors. To counter these negative stereotypes, Sarah Josepha Hale, who served as editor of Godey's Lady's Book, the most popular women's magazine of the pre-and post-Civil War era, sentimentalized the rural life in her writings. ${ }^{20}$ In Sketches of American Character, an 1843 treatise on what comprises the character of the nation, she defends rural folk by challenging any imagined epithets of "ignorant and dull" farmers and their "unfashionable and uneducated" wives and children. For the American yeomanry, as Hale advocates, are "the acknowledged sovereigns of this vast country, - they are, in our republic, entitled to respect, from their station." Admonishing her fellow town dwellers, she continues, "those who affect to look down upon the farmer and his family, to despise and ridicule the country people, exhibit a spirit which,

\footnotetext{
${ }^{19}$ Anne C. Rose, Voices of the Marketplace: American Thought and Culture, 1830-1860 (New York: Twayne, 1995), 65.

${ }^{20}$ These writings were published separately from Godey's.
} 
if it be refined and delicate, is neither enlightened, liberal, or patriotic." ${ }^{21}$ Hale, one of the women responsible for disseminating the latest fashions in Godey's, made sure to inform readers that one of the fashions of the nineteenth century was to respect the industrious and virtuous men and women braving the hardships of untamed countryside.

In the final chapter of her Sketches of American Character, Hale uses the narrative of Owen Ashley as a cautionary tale. Taking place in 1813 during the earlier days of geographical expansion, Mr. Ashley, a Boston resident, was "as fine a gentleman as could be found in the city." His New England roots, however, clouded his sensibilities as he "indulged in an overweaning conceit of the privilege he enjoyed in being a native of the metropolis of New England." ${ }^{22}$ Since his father bankrupted the family, however, Mr. Ashley was forced to move to the countryside. Rooted in ideas of New England's urban superiority, Mr. Ashley hesitantly exiled himself out of necessity, to the rural backwoods of Vermont, west of the Green Mountains, with the chronicles of his journey addressed to a friend named Edward.

At first, Mr. Ashley is hesitant to embrace his new life because of his eastern conceptions of the countryside. He admits he had always "regarded the countrypeople as objects of compassion, because they were obliged to live in such a place...I always retained the idea, that the advantages of a polite education were, in New England, confined to Boston and its vicinity." After moving out to the country and spending only a few weeks there, however, Ashley's lifelong notions the country are flipped upside down. He writes: “...a young lady may possess a refined taste, and cultivated mind and manners, may be accomplished in your sense of that fashionable word, without having even been beyond the atmosphere of Vermont; and...country

\footnotetext{
${ }^{21}$ Sarah Josepha Hale, Sketches of American Character. (Philadelphia: Perkins \& Purves, 1843), 260, https://archive.org/details/sketchesofameric00hale/page/n3/mode/2up.

${ }^{22}$ Hale, Sketches of American Character, 261.
} 
farmers may be men of intelligence and literature, and may be well-bred and agreeable, in short, gentlemen in manners and conversation." 23 While urban dwellers in the East may have regarded the denizens of backwoods regions as objects of compassion because they were living in a "backwards" state, Ashley's first few weeks in the country proved to him that his Bostonian stereotypes were incorrect. Women in western Vermont actively adhered to eastern definitions of womanhood and respectability, and men could have reputable familial roots and be a gentleman in every sense of the word, regardless of environment.

Ashley also emphasizes the self-sufficiency of rural Americans. Rather than continuing to regard them as objects needing compassion for living in such a state, Ashley notes with admiration that country farmers work for themselves. Comparing with the city environment, Ashley notes that:

All large cities must of necessity be similar in one striking feature - the disparity in the condition of its citizens...But the country, the country has none of this. Here there is no ignorance, or want or poverty, such as you have seen exhibited. Plenty of work there is to be sure, and the people work hard, but then it is fashionable to work, they do not feel degraded and are not degraded by it. They labor for themselves; there is no landlord or tenant; no hired dwellings; no rent to press like an incubus, and destroy the sleep of the weary. ${ }^{24}$

With this, Ashley starts utilizing the pastoral ideal to point out commonly perceived problems in eastern urban centers. While there is plenty of work to be done on rural farms, he notes that these farmers are truly free - they are working for themselves, cultivating the land for themselves, and working for the good of their communities. They are living in simplicity, but everyone is on an equal playing field unlike the cities. Thus, Ashley's perceptions start to shift in

${ }^{23}$ Hale, Sketches of American Character, 276.

${ }^{24}$ Hale, Sketches of American Character, 285-86. 
favor of the countryside; it becomes a utopian pastoral space for him, as no one suffers from poverty or ignorance, everyone is independent and works hard, and unlike the city, no corrupt landlords prey on the souls of the weak and impoverished, who must scrape a living together.

During his initial move to the countryside, Mr. Ashley stays with a family on their farm, and notes their kindness and hospitality. In addition, one family member, Catharine, catches his eye in particular. He notes to Edward that she is "the loveliest girl I ever beheld. There she sits, looking so meek and innocent as she bends her head closer to her work..." With his eye for Catharine, Mr. Ashley also notes feeling happy when welcomed into the family circle. In this instance, Hale uses a common sentimental trope: the image of the warm family hearth and the innocent girl. Since the home was the focal point of republican virtue, and women were viewed as innately virtuous, they were often evoked as sentimental images for men to be enamored byand to be reminded of their own virtue.

As Mr. Ashley spends more time in the country and with Catharine, he notes more how much he loves his country, admitting his foolishness for adhering to stereotypes before. As he states to Edward, "I am ashamed of my ignorance, and I declare to you, that those dwellers in your proud city, who have lived little beyond it, are hardly better qualified to judge of the benefits of our free institutions and the peculiar character of our country people, than are those who have always lived beneath a royal government." ${ }^{25}$ Mr. Ashley, having learned his lesson about ignorance toward the countryside without having experienced it first, admonishes his New England peers against making the same mistake. Disavowing his previous pretensions toward the city, he has fully realized pastoral virtues; the corruptible nature of cities made urban dwellers comparable to subjects of a monarchy while rural folk were true republicans. Having previously

\footnotetext{
${ }^{25}$ Hale, Sketches of American Character, 281, 285.
} 
seen Boston as the "cradle of liberty," and the country as backwards and infested with bumpkin farmers, Mr. Ashley now describes the western countryside as:

The country is the strength of our Republic. Luxury may enervate our cities, but through our wide spread country, the healthful tide of liberty will still flow uncorrupted. There is no other land where the people are so free, so virtuous, so intelligent, so happy. I no longer connect the idea of American greatness, with the greatness of our cities. Should a foreigner ask me to show him the great blessings of our boasted freedom, I would send him on a six months' tour of the independent yeomanry of our land, - the peasantry, as he would call them, Edward. I am a patriot; I love my country, and - why should I deny to you? -I love Catharine. ${ }^{26}$

Originally embarrassed to be leaving the civilized cradle of his Bostonian home, Mr. Ashley reluctantly moved to the countryside out of financial necessity. Feeling ashamed and embarrassed, his attitude began to change the more time he spent amongst agrarian folk. He learned how refined, hardworking, and industrious they are. In the rural women, he also noted refinement, but additionally intelligence, virtue, and beauty. By the end of his tale, Boston is in the background — he now confidently calls himself a true patriot, for he knows the independent and virtuous character of the independent yeomen of rural America. He no longer associates American success and character with the bustling city, but with the free, independent, virtuous rural farmers. Mr. Ashley stands ready to challenge anyone who would question his patriotism or look down upon the virtue of the country. The tides of the pastoral ideal swept over Mr. Ashley, so that he fell in love with the virtuous republican character of pastoral America, and not surprisingly, a simple rural woman.

The themes of frontier sentimentalism that were later applied to the western frontier were thus present in pastoral stories situated along the eastern seaboard. For Catharine Maria

\footnotetext{
${ }^{26}$ Hale, Sketches of American Character, 286-87.
} 
Sedgwick, the idealized characteristics of pastoral America and its women were especially present in her 1836 novel The Poor Rich Man, and the Rich Poor Man, a tale set in Essex, a New England village. Among the notable aspects of sentimentalism in Sedgwick's work is that, like Hale, she idealizes hard work, emphasizing the virtue to the point where it seems she is idealizing the rural working class. Acknowledging this group, she advises that "The labouring classes ought not to lose the pleasures, that in the country, are before them from dawn to twilight. Pleasures that might counterbalance, and often do, the profits of the merchant, pent in his city counting-house; and all the honors the lawyer earns between the court-rooms and his office."27 Here, Sedgwick implies that their work were more pleasurable and virtuous than an urban merchant or lawyer confined in an urban setting.

Along the same vein, Sedgwick believes the rural working class to be privileged in their setting and lives. She then weaves the rural pastoral ideal into the industrious virtue of sentimentalism and the pastoral ideal by stating:

We only wish that more was made of the privilege of country life; that the farmer's wife would steal some moments from her cares to pint out to her children the beauties of nature, whether amid the hills and valleys of our inland country, or on the sublime shores of the ocean. Over the city, too, hangs the vault of heaven 'thick inlaid' with the witnesses of God's power and goodness-his altars are everywhere. ${ }^{28}$

Sedgwick was a staunch proponent of republican motherhood, or the notion that women's innate virtue would preserve the republic through their raising of virtuous future citizens. That virtue, for her, included an appreciation of nature, as she advised rural mothers that they have a

\footnotetext{
${ }^{27}$ Catharine Maria Sedgwick, The Poor Rich Man, and the Rich Poor Man (New York: Harper \& Brothers, CliffStreet, 1836), 32.

${ }^{28}$ Sedgwick, The Poor Rich Man and the Rich Poor Man, 32.
} 
responsibility to instill in their children a love of nature along with their industry. She also advises those in cities to emulate this love of nature. While those in cities did not have what she viewed as the privilege of country life, they could seek to emulate the virtues associated with it by finding natural beauty around them; for if nature's beauty could still be found in the city, it ceased to be a center of capitalist corruption and could still keep nurture American pastoral virtues.

Sedgwick's tale follows a man named Philip May, or Uncle Phil, who life was characterized by a chain of misfortunes. He lost one of his children, his workshop, and his wife. Yet, as Sedgwick's title denotes, while Uncle Phil was technically a poor man, his life was rich. Sedgwick paints a picture of Phil as an honorable man who had no vices and "was temperate and frugal in his habits, and a striking illustration of how far these virtues alone will sustain a man even in worldly matters." In true sentimental fashion, however, it was the women in his life who helped preserve and cultivate these virtues. Prior to his wife's death, "his small supplies were so well managed by his wife, that no want was felt by his family during her life." After their mother's passing, Philip's young daughters Charlotte and Susan took over the role of preserving the integrity of their home. Acknowledging the importance of industry characteristic of rural settings, Sedgwick points out that "industry and frugality are wonderful multipliers of small means. Philip May brought in little, but that little was well administered. His house was cleanhis garden productive (the girls kept it wed [sic]) — his furniture carefully preserved—his family comfortably clad, and his girls schooled. No wonder Uncle Phil never dreamed he was a poor man!" ${ }^{29}$ Sedgwick's characterization of Uncle Phil showcased the values she wants to encourage her audience to emulate. Phil was a good man who endured a string of misfortunes, but he

\footnotetext{
${ }^{29}$ Sedgwick, The Poor Rich Man, and the Rich Poor Man, 18-19.
} 
remained free of true poverty and destitution because of the women in his life; capitalistic greed did not make him rich, but the virtuous women who surrounded him did. His wife and later his daughters served as his moral guardians, as industry, economy, and respectability were what kept both Philip and the household afloat. Thus, Sedgwick's fictional women fulfill their duties of keeping the men in their lives on track through simple virtues of industry and economy.

In her work, Sedgwick also makes commentaries directed at fashionable men and women, where she invites the men and women who indulge in fashionable elegance "to peep into the dwelling of our young friends, and witness the actual happiness resulting from the success and expedients and infinite ingenuity of the poor." Susan and Charlotte often had to repurpose clothes for Uncle Phil and themselves and going to a tailor's shop was a luxury. When Uncle Phil and Charlotte had to make a journey to New York to see a physician due to an illness that plagued Charlotte, the two women realized that his clothes needed more than their touch to give him a respectable and tasteful appearance in a place where he was not known. Susan, through practicing good economy, was able to repurpose old cloaks to make their father presentable. After Susan worked out the tight clothing budget and how they would repurpose old dresses with her sister, she resolved to buy Charlotte a new riband. ${ }^{30}$

Since Charlotte was ill and Susan wanted her sister to have something new for New York, she went to Mr. Turner's shop to purchase a riband for cheap. As she perused the shop, Susan said "How lucky Mr. Turner is selling off-I wonder what colour I had best getCharlotte would like brown, it's so durable—but she looks so pretty in pink. It takes off her pale look, and casts such a rosy shadow on her cheek. But I am afraid she will think pink too gay for

\footnotetext{
${ }^{30}$ Sedgwick, The Poor Rich Man, and the Rich Poor Man, 22-23.
} 
her." She was not thinking about elegance, but what colors would highlight her sister's inner beauty and sincerity while also being practical and functional. Susan was "weighing utility and sobriety against taste and becomingness." As she walked up to the counter, Susan spotted in a glass case "a brown and plaid riband. Her own taste was gratified, and Charlotte's economy and preference of modest colours [sic] would be satisfied — in short, it was (all women will understand me) just the thing." Valuing sincerity, utility, and economy above elegance and adornment, Susan delighted in her simple yet tasteful purchase for her sister. In her appeal to fashionable individuals, Sedgwick again emphasizes that while Susan made a rather simple and cheap purchase, she was richer for it because she adhered to that virtuous simplicity that characterized rural - and frontier — settings. After all, Sedgwick asks "which was richest (in the true sense of the word), the buyer of Cashmire [sic] shawls and blonde capes, or our little friend Susan?"31

Charlotte and Uncle Phil later returned from their journey to the comforts of Susan and their simple home; yet the physician's examination declared Charlotte's illness incurable. Through Charlotte's innate character, however, she would hold onto her health and life. After an initial examination declared her incurable, the physician takes particular note of Charlotte's characteristics. He found Charlotte to be "judicious, rational, self-denying, steadfast, humble, and patient; he then proceeded to give his advice, not with the promise of curing her, but with the well-grounded expectation of protracting her life, and rendering it comparatively comfortable to herself and useful to others." While a common trope in sentimental literature was that the most virtuous and pure character dies because they are too good for the corrupt world, Sedgwick turns this on its head, as Charlotte's simple virtues and the pure rural setting she lived in made her

\footnotetext{
${ }^{31}$ Sedgwick, The Poor Rich Man, and the Rich Poor Man, 23.
} 
worthy of living longer and not succumbing to her disease. ${ }^{32}$ Sedgwick's character is recommended a hearty and simple diet that would "have sent half the people in our cities into a fit," and to take advantage of nature's beauty and the open air. As the physician states, "The poor are saved by the invigorating effect of labour $[$ sic] in the open air-when they are saved — but sickness and death often ensue." Additionally, the doctor recommends that Charlotte's clothing now be made extensively of flannel (a material noted to be used on the frontier as well), because the simpler fabric would help the ill woman brave the harsh climate. ${ }^{33}$ In a note at the end of this chapter, Sedgwick directly addresses her readers: "A friend of mine proposed that New-England artists should paint the goddess of health with flannel drawers in her hand." ${ }^{34}$ In other words, Sedgwick proposes that artistic representations of health in America should reflect the simple virtues rather than aristocratic elegance.

Sedgwick's sentimental tale is, ultimately, one of instruction and criticism, which was common in sentimental literature. If Charlotte May was able to sustain her life longer due to her republican virtues of industry, self-denial, and economy, then the character of Paulina Clark serves as her critical foil. Paulina is the embodiment of the fashionable woman, her virtue corrupted by vanity and frivolity. Charlotte, once gravely ill, "by strict temperance, by regular exercise, by prudence and thoughtfulness," had been able to preserve her health. By preserving her republican virtue and the sense of duty and self-denial, she had "preserved that sweet serenity of spirit that shone through her pale face, and all those faculties in active operation, that slender and fragile as she was, made her the comfort of her family." Paulina, on the other hand, had suffered misfortunes just like Charlotte; after her stepfather's death, she and her mother moved

\footnotetext{
${ }^{32}$ The most popular example of this is Little Eva in Stowe's Uncle Tom's Cabin.

33 "Pioneer Lady: Peoria’s Secret Scribe," Milner Library, https://transcription.library.illinoisstate.edu/collections/show/3.

${ }^{34}$ Sedgwick, The Poor Rich Man, and the Rich Poor Man, 37-53.
} 
back to Essex with the fortune left to them. Paulina lived off her inherited wealth extravagantly, until leaving town when the third man her mother was betrothed to ran away with their fortune. Unschooled in the virtues of ingenuity, self-denial, and economy, Paulina could not adapt to her new situation and fell into a state of destitution. ${ }^{35}$

Years prior to her corruption via monetary wealth, Paulina would have been on par with Charlotte and possessed the qualities sentimentalized in rural women. She was "good-humored, bright, courageous, and kind-hearted." Sedgwick paints Paulina's mother as an example of a failure of a republican mother by always chasing after wealthy husbands instead of embracing simpler virtues to sustain her in life. Paulina is described as pretty, but, without true virtue, she is not beautiful like Charlotte. As Sedgwick warns, "That love of dress which pervades all classes of women, which grows with their growth and strengthens with their strength, which is cherished by the conversation of their own sex and flattery of the other, which degrades the rich and ruins so many poor girls, was one of the most efficient causes of Paulina's destruction." ${ }^{36}$ The distinctions between these characters encapsulate Sedgwick's work: through them, she sentimentalizes and encourages republican virtues. These simpler virtues of self-denial, industry, and economy not only cultivated true inner, and outer, beauty, as Sedgwick emphasizes, republican women were responsible for integrating them into American identity.

Of course, the metaphorical elephant in the room of Sedgwick's work, and that of other sentimental authors, is that it warns of the dangers of capitalism while ignoring the systemic and institutional realities of class disparities. Here, Sedgwick uses rhetoric that not only imagined the rural areas as a terrain free of poverty, but that promoted frontier virtues as a democratizing force

\footnotetext{
${ }^{35}$ Sedgwick, The Poor Rich Man, and the Rich Poor Man, 53-63, 165.

${ }^{36}$ Sedgwick, The Poor Rich Man, and the Rich Poor Man, 166.
} 
that could save anyone from poverty and destitution. This rhetoric helped cement American identity as a rural utopia where anyone willing to work hard could climb the social ladder with ease thanks to the abundance of land; yet the reality of that vision depended upon one's race and gender. As Greg Grandin simply puts it, this rhetoric created a type of American moralism that "celebrates the rich and punishes the poor...allowing the United States to avoid a true reckoning with its social problems, such as economic inequality and racism.”37

For writers like Sedgwick—especially since Sedgwick was in New York, likely seeing the capitalist urban chaos and class disparities - the pastoral ideal allowed them to create the America they wanted. As urban centers grew throughout the nineteenth century and capitalism tightened its hold along the East Coast especially, incorporating rural virtues into sentimental culture preserved the nation's virtuous republican foundation. Overall, Sedgwick's work served as a reminder to nineteenth-century women that if they fell under the spell of the urban capitalist setting and forgot their republican virtues, then the nation was doomed. Women were at the very core of America's image, for they were actively cultivating and preserving it; sentimentalism was a tool with which they did so.

By the mid-nineteenth century, the image of the hardworking, self-sufficient American who embodied American greatness came to be associated with the West, beyond the Appalachian Mountains. Publications such as Godey's published stories that attributed the nation's industrious and self-sufficient character to the West. An 1857 issue, for example, admired the beauty of nature as well as its need to be conquered, noting that "the picture of industry is associated in our idea of western greatness, because nature there is strong as well as

\footnotetext{
${ }^{37}$ Greg Grandin, The End of the Myth: From the Frontier to the Border Wall in the Mind of America (New York: Metropolitan Books, 2019), 4.
} 
beautiful, and requires to be subdued." The piece then presents a fictional sketch submitted by a Godey's correspondent of two women discussing their ideas of the West. One woman, Minna, found it distasteful that Mrs. Lenwood was living out West without the comforts of the East, managing her household without help. Finding Minna's perception of the West misguided, Mrs. Lenwood informs her that it is fashionable to do one's own work on the frontier. She states that many travelers who write declension narratives of people with magnificent estates in the East exchanging their beautiful homes for "wild log cabins" in the West are not usually true. Countering these perceptions, Mrs. Lenwood advocates:

A majority of the inhabitants of this country are of that class of your eastern citizens who are active, energetic business men, who have felt that their ambitious natures were much too cramped in the more densely populated States of the East; and they come here with families, who partake of the same aspiring nature; and it has the effect to turn the tide of public opinion in favor of domestic industry. Here it is no disgrace to labor; and the woman who has the time and ability to perform her domestic duties alone does not think of it as keeping help. ${ }^{38}$

In her description of the West, Mrs. Lenwood shows that ambitious and industrious men migrate West with their families to have a better life. Women, too, can also be more respectable and self-sufficient on the frontier, and do not disgrace anything by dutifully doing their own work. With this narrative, Godey's presented the frontierswomen as a counterpoint to any negative eastern misperceptions and sentimentalized them in the name of industry and virtue.

Along with distributing advice for a virtuous domestic life, Godey's also promoted republican virtue by hearkening back to its roots in the Revolutionary era. Showcasing narratives

\footnotetext{
38 "Editors' Table: A Young Lady's Ideas of Western Life. Reply to the Wish of a Young Lady. Places of Education for Young Women." Godey's Lady's Book and Magazine 5, (1857): 465, http://libproxy.lib.ilstu.edu/login?url=https://www-proquestcom.libproxy.lib.ilstu.edu/docview/126089174?accountid=11578.
} 
of "The Heroic Women of America," the first installment "The Lady and the Arrows," tells the story of a woman named Mrs. Motte, who righteously sacrificed her self-interest by accommodating some soldiers fighting in the American Revolution during the siege of Fort Motte. Her actions, "by which she sacrificed her own property to the demands of patriotism, was so graceful, so generous, and free, that it has occasioned her praises to be celebrated in all the histories of the time." Mrs. Motte's hospitality and generosity extended to even "the lowest of the ranks," and when she learned that in the battle her residence would end up destroyed, she "declared that she joyfully gave her house to the good of her country, and should delight to see it in flames." She assisted Colonel Lee by giving him a bow and arrows her husband had, and after the soldiers were driven down, Mrs. Motte invited both parties to a dinner she made, where "the unaffected politeness of the patriotic lady soothing the angry feelings which the conflict had engendered, and obliterating from the memory of the gallant whigs the recollection of the injuries she had unavoidably sustained at their hands." ${ }^{39}$ Mrs. Motte, then, embodied the virtue also attributed to frontierswomen through her hospitality; her patriotic self-sacrifice helped win the battle, and her politeness afterward softened the aggressive masculine conflict on both sides, reigning the men of war back into the "civilized" world.

This heroic and patriotic self-sacrifice was applied to frontierswomen specifically in frontier sentimentalism. Pioneer women emigrating West had to sacrifice some comforts and conveniences of city living to bring "civilization" to the Western wilderness while preserving notions of republican virtue. Like traditional sentimentalism in the East, frontier sentimentalism was a racialized concept, with white women being the only acceptable channels for "civilization"

\footnotetext{
39 “'Heroic Women of America. -No. 1. The Lady and the Arrows." Godey's Lady's Book, 29 (July to December
} 1844): 229-230. https://archive.org/details/Godey29/page/n251/mode/2up?q=pioneer. 
to expand out West. Despite the anxieties frontierswomen may have experienced in emigrating West, they also felt a sense of duty to practice self-denial for the good of their families, communities, and the preservation of a virtuous American character. It is not surprising, then, that the frontier and frontierswomen often became associated with the patriotism embedded in the revolutionary founding of the nation.

John Frost, a nineteenth-century observer and author of American history, idealized frontierswomen in these ways in his works about westward expansion. Finding the experiences of frontierswomen brave, noble, and educational, Frost stated that their writings "teach us what women are capable of; they show us how dearly the blessings we now enjoy were purchased by those who went before us in the march of the ages, they furnish abundant themes for meditation and studies in the mysteries of human character..."40 Due to their lofty cultural roles in the western wilderness, women were not only essential to the nation's expansion, but they were further sentimentalized for their roles in doing so.

Women were already perceived as inherently more suited to sentimental culture, but the frontier heightened this perception. For instance, in the 1840 s the infamous Donner Party faced a series of mishaps on their route to California, and the group nearly perished after taking the Hastings Cutoff and became trapped during the winter of 1846 . Their story became one of the most popular frontier narratives and appeared frequently in the growing body of frontier literature. The misfortune that had befallen the Donner Party, however, helped validate frontier sentimentalism and the essential status of women inherent in it. Women in the party like Mrs. Foster had suffered great misfortune and were heroines because they were capable of

\footnotetext{
${ }^{40}$ Frost, Daring and Heroic Deeds of American Women, 8.
} 
withstanding it, but also because they were willing to sacrifice themselves for their husbands and children. When the men began to crumble under unbearable misery, the women, Frost observed, "persevered an unmurmuring calmness, and an unflinching energy." The latent sentimental powers of women shined through in crisis:

The genuine strength of human creatures - the power of the soul over the body - was there shown to be possessed in a greater degree by woman than man - amid the savage winter of the wilderness, among horrid feasts, when to save themselves from death, men became brutes, women's true nobility shone forth in all its splendor. ${ }^{41}$

In some ways, the unfortunate tale of the Donner Party served as a jeremiad of sorts to American men: without women's inherent self-sacrificing virtue to balance them out in times of crisis or misfortune, they risked a racial declension into "uncivilized savagery." In this case, the racialized undertones of frontier sentimentalism are teased out again, as the remaining men of the Donner Party were faced with becoming "savages" and "brutes" without women's powerful souls and nobility to guide them out of crisis and bring them to the light of "civilization" again.

Frontier sentimentalism imagined the West to ease anxieties about the city, and other genres of literature did the same, even while parodying frontier sentimentalism—and eastern gentility—in the process. The Davy Crockett almanacs, popular with male readers, serve as an example. As Carroll Smith-Rosenberg has shown, the multiple male authors of the Crockett almanacs feared that genteel codes of behavior stripped them of their masculinity. The almanacs, then, allowed these men to escape into a frontier fantasy of wild and brute manliness. The Crockett almanacs presented stark contrast between frontier manliness and eastern gentility. Crockett was "loose, liminal, and wild," the foil of the patriarchal father fulfilling family

\footnotetext{
${ }^{41}$ Frost, Daring and Heroic Deeds of American Women, 267.
} 
obligations. Escaping the chains of patriarchal civilization, Crockett finds freedom in the wilderness, where he is free to be as Smith-Rosenberg describes, "man turned beast, the white man who scalps Indians, the uncultured civilizer. He lives beyond boundaries, on rivers, literally between states." ${ }^{42}$ In the Crockett universe, the West was a world of solace separate from the rigid world of eastern gentility, a childlike fantasy escape where one could truly be their "true self"-which was "primitive, beastlike, and uncultured."

Crockett's world also criticized the rigid gender roles in the East by presenting images of frontierswomen that stood in sharp contrast to their genteel and delicate urban counterparts. Yet, in exaggerating these images, the almanacs appear to be poking fun at tropes of frontier sentimentalism. As Smith-Rosenberg points out, the women of Crockett's Wild West "systematically violated the system of rigid properties which the Cult of True Womanhood imposed upon bourgeois women. They drank, toted guns, wielded knives, killed or tamed animals, and defended their beaux and husbands when the men were attacked by wild animals or other wild men." The women in the almanac universe were autonomous and, like Crockett, challenged traditional middle-class familial structures. Outside of the unyielding parameters of eastern civilization, these women expressed more sexual autonomy, freely bundling (sharing a bed while unmarried) with men they happened across in the woods. For instance, in one episode, Crockett comes across a woman (who remains nameless throughout the episode) whom he asks to bundle with him. She states that she cannot marry him, but she will bundle with him. In an occurrence that exaggerates the resourcefulness of frontierswomen while parodying eastern traditional womanhood, Crockett and the woman start walking to her father's home, but on the

\footnotetext{
${ }^{42}$ Smith-Rosenberg, Disorderly Conduct: Visions of Gender in Victorian America. (New York: Oxford University Press, 1985), 95-101.
} 
way back her garter snaps. This woman, however, was a "modern frontier virgin," and she "picked up a rattlesnake from his nest, knocked out his brains with a stone, and tied him around her leg as a garter. After doing this she tells Crockett that she "could not play on the piano nor sing like a nightingale, but she could outscream a catamount and jump over her own shadow." ${ }^{43}$

The minds behind the Crockett almanacs thought eastern women too preoccupied with fashion magazines and trivial vanity, so they foiled them with resourceful yet wild frontierswomen who used rattlesnakes for garters or wore bearskins. For instance, Colonel Coon's wife, Judy, “wore a bearskin petticoat, an alligator's hide for an overcoat, an eagle's nest for a hat with a wild cat's tail for a feather... [She] sucked forty rattlesnake's eggs...to give her sweet breath the night she was married." ${ }^{44}$ Eastern women were disparaged the hypocrisy of their fashion, while their frontier sisters were imagined as being too embedded in the "uncivilized wilderness" to even care about appearances. The almanacs thus took images of pioneer women common in frontier sentimentalism and turned them into grotesque caricatures.

Yet, the almanac writers shared with frontier sentimentalists a distaste for New England commercial ambition and emerging bourgeois professions. The West represented the opposite of bourgeois capitalist ambition in the East, as, according to Smith-Rosenberg, "the New England peddler always appeared a ludicrous character who is tricked and finally banished by resourceful frontier women and men." Because these individuals were countering republican virtue and embodying everything that was wrong with nineteenth century urban American society in the eyes of cultural commentators, these nonsensical characters were all depicted as "fleeing a West too wild and frightening for them." ${ }^{45}$ As Slotkin points out, the Crockett myths are "difficult to

\footnotetext{
${ }^{43}$ Smith-Rosenberg, Disorderly Conduct, 104.

${ }^{44}$ Smith-Rosenberg, Disorderly Conduct, 103.

${ }^{45}$ Smith-Rosenberg, Disorderly Conduct, 103.
} 
unravel." On one hand, Crockett is "a product of the eastern stereotype of the frontiersman as a lowbrow and a clown." On the other, he is "clearly a product of western popular literature--a clown whose apparent simplicity masks a cleverness that is superior to city wit and a human sensitivity more profound than the effusive sentimentality of the city, for all its being concealed under a bantering, ironic manner." ${ }^{46}$ Thus, even while presenting an exaggerated vision of the West, the Crockett almanacs still adhered to the literary trend that framed the frontier as a place of myth while criticizing transformations along the east coast.

Unlike the Crockett parodies, frontier sentimentalism placed women at center stageenterprising men moved the frontier geographically, but the women were its cultural conservators. In his work, Frost touched on eastern perceptions of the frontier, stating that the "denizens of the Eastern States of our glorious union are accustomed to regarding the west as the regions of romance and adventure - a sort of American fairy land, whose people are ennobled by generous and chivalric sentiments, whose history abounds with thrilling adventures..." Behind this romantic perception, however, Frost acknowledged that the prosperity of the West by the 1860s was built upon the efforts of earlier settlers. By "winning” the country from Native Americans, frontier men "signalized themselves by prodigies of valor, enterprise, and endurance." Not surprisingly, behind every enterprising man was a woman who "rivalled them in all these virtues, affording often the most splendid examples of that spirit of self-sacrifice and devotion that can only be prompted by disinterested affection." ${ }^{47}$ The pioneer mothers Frost sentimentalized were heroines because they patriotically sacrificed themselves for their families, and preserved civilization by spreading it to the "savage" lands.

\footnotetext{
${ }^{46}$ Slotkin, Regeneration Through Violence, 414.

${ }^{47}$ Frost, Daring and Heroic Deeds of American Women, 7-8.
} 
The eastern seaboard oftentimes sentimentalized frontier women as heroines through assigning them the "civilizer" role. The western wilderness was just a dark and barbarous place until women came and brought their "civilizing" virtue to it, transforming it to be a point of American pride and patriotism. By the 1860s, westward expansion was in full swing geographically, as well as sentimental productions of its women. Frost illustrated the qualities present in frontier sentimentalism with his representations of "pioneer mothers," pointing out example of their "courage, fortitude, devotedness, and self-sacrifice." The frontier heroine, unlike the satirical Crockett almanacs, was not masculinized, because her heroism is "of the heart. Her deeds of daring and endurance are prompted by affection.” Thus, the strong, courageous, pioneer woman was still a sentimental woman of feeling because her deeds and emotions were tied to her role as a woman. Her dedication to her familial foundation reigned supreme, and she upheld civilization when threatened by Indians. Since the virtuous woman was at the heart of the household and therefore responsible for molding virtuous republican Americans, the family was central to notions of civilization. Indians posed a threat to "civilized" order because of their alleged "savage" nature - it was feared that they would destroy families through kidnapping and violence. The family and household, the foundation of republican virtue is in danger, "when the lurking savage is seen near the dwelling, or the war whoop is heard in the surrounding woods, the matron becomes a heroine, and is ready to peril life, without a moment's hesitation, in the approaching conflict." 48 In this way, the pioneer woman was valued as heroic and strong because, through her virtue, she was upholding white "civilization," and Native Americans were viewed as its antithesis.

\footnotetext{
${ }^{48}$ John Frost, Daring and Heroic Deeds of American Women, Comprising Thrilling Examples of Courage, Fortitude, Devotedness, and Self-Sacrifice, Among the Pioneer Mothers of the Western Country (Philadelphia: G.G. Evans, 1860), iii. https://archive.org/details/daringandheroic00frosgoog/page/n12/mode/2up.
} 
Popular nineteenth-century magazines also sentimentalized pioneer heroines as harbingers of American “civilization.” In an 1857 issue of Godey's, a story titled "The Pioneer's Daughter" follows Amy Staunton on the eve of her nuptials to Charles, her betrothed. While dutifully tending to her tasks on her family's log cabin tenement, Staunton's family and Charles are kidnapped by Indians. They are bound and marched away from their homestead, until they camp for the night. Stories of white Americans taken captive by Natives were another popular literary genre, dating back to the seventeenth century, and this genre often overlapped with frontier sentimentalism. This particular narrative highlighted Staunton's unwavering resolve, as she freed Charles in the middle of the night and seized a gun, daring to make an escape. The fairytale-like courage of Amy Staunton highlights her self-sacrifice, which in women were deemed essential for familial and community virtue:

The high courage of the pioneer's daughter rose with emergency. She thought of her gray-haired father and her promising young brother, whose lives were dearer and more valuable than her own; she thought of the homes that would be made desolate by the deed that was meditated; and she thought of the lasting injury it would be to the settlement if so many brave men were cut off-what was her poor life when so many precious ones were at stake? ${ }^{49}$

While she was terrified of Native Americans and nervous to face them, Staunton's courage came from her sense of patriotic duty to American "civilization." Since this is a sentimental tale, however, she and most of her kidnapped cohort escaped successfully due to

\footnotetext{
${ }^{49}$ Williston, Clara P. "The Pioneer's Daughter" Godey's Lady's Book and Magazine, 7 (1857): 19, http://libproxy.lib.ilstu.edu/login?url=https://www-proquestcom.libproxy.lib.ilstu.edu/docview/126096083?accountid=11578.
} 
Staunton's bravery. After the community was reestablished in their homes, Amy and Charles were finally wed, allowing Amy to continue her duties as a loyal pioneer woman. ${ }^{50}$

At times, non-white women could be sentimentalized, but only by adopting the ideals of white womanhood. Stories in this vein showcased a narrative arc that moved from "savagery" to "civilization," emphasizing the very same transition that white women risked in moving into the wild only to uphold civilization. In one instance, Godey's reimagined the narrative of Pocahontas in a tale called "The Snow Feather." While this story is set in seventeenth century Virginia and not "the West," nineteenth-century readers would have read it through the lens of the contemporary western frontier. The story starts with, "To the woods - to the woods, gentle reader. Release your lips from their polished smile. Our path is not on crowded pavement, nor through the gleam and glitter of stately halls...Ye are going out into the solemn and beautiful woods— by your patriotism, my lovely lady reader, frown not." ${ }^{51}$ From the outset, the story immerses readers in the beauty of nature while associating it with the patriotism that comes with its simple virtues.

The Snow Feather, a "savage" maiden, was an Indian princess who was one with romantic scenes of nature. Yet, she had the aspirations of a white woman, having dreams of joining "civilized" society. With the rest of her tribe wondering why she is seemingly unhappy since she is the chief's daughter and occupies a high position, the Snow Feather visits the temple to talk to her prophet and discuss her dreams. He assures her that her dreams will soon make sense, and she will soon go to another land. After this, she goes to the river basin to dump shells

\footnotetext{
${ }^{50}$ Williston, Clara P. "The Pioneer's Daughter" Godey's Lady's Book and Magazine, 7 (1857): 16-20, http://libproxy.lib.ilstu.edu/login?url=https://www-proquestcom.libproxy.lib.ilstu.edu/docview/126096083?accountid=11578.

51 "The Snow Feather; A Tale," Godey's Lady's Book, 7 (July, 1833): 1-11, https://hdl.handle.net/2027/njp.32101064241860? urlappend=\%3Bseq $=13$.
} 
her brother offered to her that morning into the water when suddenly, the Snow Feather's seemingly joyless future has meaning when she has a vision — "the picture was her in a girdle, its image had been reared already in the holy places of her heart, and every idle thought and affection came thronging to the worship. From that hour a wild and splendid dream of hope brightened her existence." ${ }^{52}$

A few days later, the prophet's assurances that the Snow Feather would have answers to her dream came to fruition when "pale intruders" encroached upon their land. After her tribe captured a white man — a nameless "John Smith" figure—she came to gaze upon him. After learning from warriors that he was to die tomorrow, the Snow Feather leaps in and saves him, convincing her father that he must not die. After saving a white man, the Snow Feather's visions come to fruition when she goes to England with him to get married and become "Rebecca," now a "respectable" and "civilized" woman. ${ }^{53}$

With this, Godey's disseminated a virtuous image of an "Indian princess" who was already one with nature but had an innate desire to aspire to the virtuous romantic ideal of white women. Having been born and raised among the romantic scenes of nature, the Snow Feather reversed the migration of westering women, moving instead from the wilderness to "civilization." This also served as an inverse of the captivity narrative genre in which a white person is captured by "savage" Indians. Here, the Snow Feather instead heroically saved a white man and decided to marry him and build a life together in white society. In this case, the Snow Feather had qualities of sentimentalized republican virtue attributed to her: moving from "Indian

\footnotetext{
52 “The Snow Feather; A Tale,” Godey’s Lady’s Book, 7 (July, 1833): 1-11, https://hdl.handle.net/2027/njp.32101064241860?urlappend=\%3Bseq=13.

53 "The Snow Feather; A Tale," Godey's Lady's Book, 7 (July, 1833): 1-11, https://hdl.handle.net/2027/njp.32101064241860?urlappend=\%3Bseq $=13$.
} 
princess" to "noble maiden" Rebecca, she was in touch with the simplistic virtues of nature and also possessed the ability to become a respectable lady by white society's standards. This attribution of virtue to Native American women became an aspect of frontier sentimentalism and subsequently part of America's mythic identity. This further distanced America from Europe, for as Slotkin points out, "The emphasis given to this positive association with the Indian distinguishes American from European treatments of the West at this time," and there was a "strong tendency in American works for the emphasis on the Indian as an exemplar of republican virtue to increase." ${ }^{\prime 54}$

Godey's was not alone in this literary tendency, as other nineteenth century writers who deployed sentimentalism to comment on American society did the same. Lydia Maria Child's novel Hobomok, A Tale of Early Times, published in 1824 under the title "An American," is a case in point. Notably, Child begins with a comment of patriotic pride, stating that she simply cannot look upon the thriving villages of New England "which speak so forcibly to the heart, of happiness and prosperity, without feeling a glow of national pride, as I say, 'this is my own, native land." She conjures up proud links with nature and industrialization as well, declaring that "A long train of associations are connected with her picturesque rivers, as they repose in their peaceful loveliness, the broad and sparkling mirror of the heavens, - and with the cultivated environs of her busy cities which seem every where [sic] blushing into a perfect Eden of fruit and flowers. ${ }^{" 55}$ Interestingly, Child does not discriminate here in her patriotic associations; she draws readers to the beauty of nature and the bustling cityscape and establishes a connection to

\footnotetext{
${ }^{54}$ Slotkin, Regeneration Through Violence, 347.

${ }^{55}$ Carolyn L. Karcher, ed. Hobomok and Other Writings on Indians (Rutgers University Press: New Jersey, 1986); Lydia Maria Child, Hobomok A Tale of Early Times (1824), 5.
} 
both, associating both landscapes with an Eden-like imagery. This initial assertion is an important one, as it serves as Child's segue into the tale of Mary Conant.

One of Child's earlier works, Hobomok takes place in 1629 among the first settlements of New England. Child uses this historic setting, however, to comment on nineteenth-century westward expansion. Conant embodies the traits of frontierswomen that popularized frontier sentimentalism, and, as both a pioneer woman and a colonial woman, she signifies the essential role of women in the formation of American identity. Child's tale of republican virtue, of course, challenges the patriarchal authority and issues warnings about the corruptible nature of man. Roger Conant, Mary's father, became the focal point of the novel's problems as Child portrays him as an antagonist. From humble beginnings, Mr. Conant only had but one ambition for his life: wealth. His primary goal was to take the hand of a wealthy woman as his avenue into money. At last, he met his wealthy match in the future Mrs. Conant (whose name is never revealed in the novel), yet her father, very displeased by this humble match, did not extend his wealth to his son-in-law. His soul became corrupted by his sole desire for wealth. For Mr. Conant and his family, "Years rolled on, and misfortune and poverty became their lot. Frustrated in his plans, thwarted by his rivals, misanthropy and gloom sunk deep down into the soul of the disappointed man." The Conants had lost two children to disease and famine; this coupled with being able achieve any monetary fortunes, they were not to stay in England; instead, they had to take the perilous journey to America to live in the wilderness. ${ }^{56}$ Thus, Mr. Conant's failures as a patriarch caused him to become bitter and troubled as his family leaves "civilization."

\footnotetext{
${ }^{56}$ Child, Hobomok, 8.
} 
This tale, however, is not about Mr. Conant, but Mary Conant's rebellion against her patriarchal Puritanical father in the wilderness. From the outset, Mary condemns her father's bigotry, storming out into the woods to perform some rebellious witchcraft. During her ritual in the woods, she meets Hobomok, a Native American, and Charles Brown, and Episcopalianboth frowned upon in Puritan society. Mary forms special connections these men, each very different, yet intertwined together through Mary. As editors of Child's work, such as Carolyn L. Karcher have pointed out, these two men represent a dichotomy of nature and culture, not opposing each other but complementing each other. Mary recalls meeting Charles back at her maternal grandfather's mansion in England, where the young woman fostered a love of art and poetry along with a thirst for intellect. Thus, Charles is associated with culture, and matches intellects with Mary, providing the foundation of their connection.

Hobomok, on the other hand, was "Unwarped by the artifices of civilized life," and described as "tall and naturally beautiful." Child applies republican virtue to Hobomok because of his distance from fashionable gentility and urban capitalism. Child portrays Hobomok with what we now see as the problematic "noble savage" stereotype that paints the Indian as a benevolent, almost motherly figure whose sole desire is to "become white" and therefore “civilized." This novel's main goal, however, was to challenge women's oppression under patriarchal rule, and Child used the sentimental literary mode to do so; through Hobomok she presents a male character who is the antithesis of the rigid patriarch. The sentimental mode was contradictory, however. On the one hand, by appealing to traditionally feminine virtues, Child humanizes the "other," - in this case the Indian —in a world that held these qualities up on a pedestal; on the other hand, Child's depiction of Indians was problematically stereotypical. Both suitors Mary's rebellious ritual conjures up in the woods represent not only her personal 
rebellion, but a key part of Child's literary commentary. ${ }^{57}$ It is through the creation of these two love interests that Child represents the spatial dichotomy of "civilization" and the "wilderness," "East" and "West" in nineteenth century America—and through Mary, Child represents the centrality of women to both spaces.

Although rebellious, Mary still has a virtuous character that stands in stark opposition to her father's tyranny. When her mother falls ill, Mary takes on the self-sacrifice so often attributed to the frontierswomen. Mary became the caretaker of her mother, for as Child writes, "For her mother's sake, she endured the mean and laborious offices which she was obliged to perform..." By the time her mother had fallen ill, Mary and Charles had established a connection, and despite Mr. Conant's bigoted rants against Episcopalians, Charles seeks Mary's hand and the two entertain notions of marrying. Even when it comes to love, however, Mary again shows noble self-sacrifice, fearing that her father would not adequately take care of her mother, and postpones their engagement until her mother has died. ${ }^{58}$

Like all sentimental literature, the novel is a morality tale. Child emphasizes that the foundation of Mary and Charles's relationship was built on love, as opposed to Mr. Conant's search for wealth over a true love match through marriage. Mary and Charles bond and form the foundation of their relationship on an intellectual and emotional level rather than a superficial, material one; they bond over their love of art and literature and the impact it could have on one's heart - the expression of feeling. In true sentimental fashion, with Charles, when Mary "found a being who understood her feelings, and who loved, as she had imagined love, her whole soul was riveted." And, in another act of patriarchal rebellion against Mr. Conant, as at his displeasure of

\footnotetext{
${ }^{57}$ Karcher, Hobomok and Other Writings on Indians, xxvi-xxviii.

${ }^{58}$ Child, Hobomok, 47-51.
} 
their relationship, "the harshness of her father tended to increase this, by rendering the stream of affection more undivided in its source." Thus, her father's disapproval only made Mary love Charles even more. Furthermore, Child emphasizes the importance of this emotional foundation for love (as opposed to the search for wealth Roger Conant went on), for she warns: "Gratified vanity proves a powerful pleader in most hearts upon such occasions; and if love itself not be induced, the resemblance passes for awhile as current coin. I say for awhile, for most of the unhappy marriages which have come under my own observation have originated in this mistake. ${ }^{" 59}$ Mary found a love match with Charles Brown, not one steeped in a vain search for material wealth like her father's marriage, but one created through an emotional foundation, showing one's authentic self. ${ }^{60}$

This union between the two lovers was not to be, however-for now, at least. Charles ended up getting banished from the settlement from Governor Endicott due to his religion, and he had to return to England. Incredibly distraught and disheartened at the departure of her lover, Mary endures the time without Charles primarily by growing closer to Hobomok. She falls even more into despair, however, after her mother and grandfather die, and Charles is believed to be lost at sea, never to be seen again. Mary had nothing waiting for her in England anymore, only Hobomok's comfort in her present situation. The scandal both in the narrative and in the realtime reception of the novel is fully fleshed out when Mary realizes Hobomok loves her, and she agrees to be his wife ${ }^{61}$ Upon the absence of advice and guidance from a motherly figure, Hobomok, as Mary's husband, contrasts Mr. Conant's patriarchal tyranny. After her great losses,

\footnotetext{
${ }^{59}$ Child, Hobomok, 47-51.

${ }^{60}$ By the nineteenth century, there was an emotional emphasis on romantic love and expressing one's ideal self with their partner rather than economic considerations. See Karen Lystra, Searching the Heart: Women, Men, and Romantic Love in Nineteenth-Century America (New York: Oxford University Press, 1989), 3-11.

${ }^{61}$ Child, Hobomok, 78-119.
} 
Child highlights Mary's mental instability, through which, as Laura Mielke points out, Hobomok becomes Mary's "motherly caregiver, showing his wife only 'tender reverence' in sharp contrast with the actions of her father." With this, Hobomok gains an elevated sentimental status with his ability to comfort Mary in her trials, and Child's readers, as Mielke states, "witness the power of sympathy, as modeled by mothers and practiced by their children, to unite Native Americans and Euro-Americans and (temporarily) sanctify interracial familial and sexual bonds." ${ }^{2}$

It is through the union of Mary and Hobomok that Child uses frontier tropes to contribute to the tailoring of a uniquely American myth. Just as nineteenth-century frontierswomen were expected to "civilize" a vast western wilderness, Mary serves this role for her new husband. Child illustrates that Hobomok is becoming more "civilized" during his marital relationship with Mary, as Mary's dearest friend, Sally Oldham, remarks "I always thought he was the best Indian I ever knew, and within these three years he has altered so much, that he seems almost like an Englishman. ${ }^{\prime 3}$ It is, therefore, through a sentimental basis of love and affection that Child's representative Indian is "civilized," rather than militaristic masculine conflict. Mary, then, like the nineteenth-century frontierswomen, served as the conduit for "civilization" through her relationship with Hobomok.

The focus indeed remains on Mary, who is Child's true interest throughout the novel. For as Melissa Ryan acknowledges, Mary is "the future mother of the republic — and the Indian is not so much a figurative double or a model husband as an available object through which Child can establish both Mary's, and her own, contribution to the national narrative.” Preserving "civilization" meant preserving the nation, and men were aggressive and vulnerable to their own

\footnotetext{
${ }^{62}$ Laura L. Mielke, "Sentiment and Space in Lydia Maria Child's Native American Writings, 1824-1870." Legacy 21, no. 2 (2004): 172-192. doi:10.1353/leg.2004.0034.

${ }^{63}$ Child, Hobomok, 137.
} 
moral declension into "savagery" in the pursuit of frontier expansion if left unchecked by women. Hence, they were, as Ryan states, "more objects than agents of the civilizing process. Only through Mary's purifying maternal body can the 'savage' be Americanized. And thus the feminine, rather than being politically, civilly, legally erased, becomes the source of America's unique literary and cultural identity—the source of nationhood itself." ${ }^{\text {64 }}$ Thus, Mary is more than just a conduit for "civilization" in this situation; Child herself, her main character, and the frontierswomen that Mary represents are the heart of American identity—-for they were the future of the republic.

What made Child's novel particularly scandalous was not only that she depicted a consensual interracial marriage between a Native American man and a white woman, but the two also had a son together. This family was not to be a unit much longer, however, as just when Mary was adjusting to her life with her husband and their son, Hobomok went out to the woods one day where a twist of fate occurred. Hobomok encountered Charles Brown, alive and returned to the settlement. Charles, of course, immediately asked about Mary and if she was married now since it had been years. Here, Hobomok exhibits that self-sacrifice often attributed to frontierswomen, and sacrifices his own happiness for Mary and Charles. He informs Charles that Mary truly loves him and loved him first. Charles, of course, denied at first, telling Hobomok that they were married, and he should rightfully cherish his wife. Further cementing his selfsacrifice, Hobomok insists that for Mary he has endured the hatred of white settlers and his own tribe, and giving a farewell speech telling Charles to go his lost love before disappearing in the woods. For his part, Charles "listened with respect and admiration to the farewell address of the

\footnotetext{
${ }^{64}$ Melissa Ryan, "Republican Mothers and Indian Wives: Lydia Maria Child's Indian Stories." ESQ: A Journal of the American Renaissance 56, no. 1 (2010): 33-70. doi:10.1353/esq.0.0046.
} 
Indian, and forgetful of every other sentiment, he eagerly pursued him, with every intention of restoring the happiness he had so nobly sacrificed." ${ }^{65}$ But it was too late, however, as Hobomok had already run off into the to dissolve his marriage, and Charles could not catch up to him. $\mathrm{He}$ turned instead to recover his lost love: Mary.

What is interesting, however, is how subtly Child incorporates frontier sentimentalism into her literary social commentary. She represents these two worlds through these two men, Charles and Hobomok. Charles is from England, well-versed in art and refined taste; Hobomok is Indigenous but has his own virtues because of his proximity to nature. Both men respect what the other represents, and even seem to want a part of it in a sense. Mary, however, completes the puzzle. The "wilderness" of early America does not corrupt her; she remains a woman through and through and inspires virtues in both men. She is able to connect with both of these men because she retains refined culture from "civilized" life but adopts the simpler virtues associated with the romanticism of nature, much like what is expected of nineteenth-century frontierswomen. Moreover, Mary bares the trials she faces with fortitude and self-sacrifice, inspiring similar qualities in both Charles and Hobomok. Both men not only survive at the end but have a respectful conversation rather than a violent encounter in the woods because of the common factor in their lives: Mary Conant. Mary's "civilizing" force has worked on both men; Hobomok does not fight Charles as is expected of a "savage," but instead sacrifices his happiness. Charles, on the other hand, does not give into patriarchal aggression or the masculine vulnerability to decline into "savage violence" as well, but instead feels for Hobomok and his noble sacrifice, and tries to find him to no avail. Thus, with this moment in the woods, Mary's elevated sentimental status as a "civilizer" comes full circle: both men make sentimental,

${ }^{65}$ Child, Hobomok, 137-141, 142. 
emotional appeals for each other's happiness, but ultimately it is Hobomok who makes the sacrifice for the white man.

In the end, Mary and Charles are reunited, and they return to the settlement - to “civilization"-with Mary's son, who Charles adopts as his own. Mary's father also gets a minor redemption arc, as he accepts Mary, her son, and now Charles with open arms, realizing his bigotry was wrong - though only because the Indian is out of the picture. Hobomok has conveniently disappeared, and his son is adopted by Charles and assimilated into Mary's white family. With this, the novel gets into Child's solution to the nineteenth century's "Indian Problem"- virtuous frontierswomen are the means for solving it through "civilization." Child's work challenges patriarchal authority and places women at the center of American cultural formation. Clearly not an advocate for masculine conquest and violent genocide, Child's solution is proposed through frontier sentimentalism: women are at the heart of the family, which, as Ryan points out, is used in the Indian novel to "expel the Indian as a relic of the past in order to establish the Anglo-Saxon nation as the exemplar of progress." Through Hobomok, Child places women at the heart of national identity, because they are the heart of the household and family, which drives American progress. Thus, it is through the family—as with Mary's union with Hobomok - that "Indianness" will be absorbed into the American landscape, eventually forgotten. Through advocating intermarriage, assimilation, and letting women's "civilizing" influence do the work, Child presented a (what she assumed would be voluntary) solution to the "Indian Problem" wherein women further facilitated "civilization" and "progress" across the American landscape. ${ }^{66}$ Thus, through literary fiction, women like Child placed themselves in the

\footnotetext{
${ }^{66}$ Melissa Ryan, "Republican Mothers and Indian Wives: Lydia Maria Child's Indian Stories." ESQ: A Journal of the American Renaissance 56, no. 1 (2010): 33-70. doi:10.1353/esq.0.0046.
} 
center of the American landscape rather than on the margins; they were essential to national identity and progress.

Ultimately, women were essential contributors to the American mythos that came to be associated with the frontier, as they were the natural preservers of "civilization," the heart of the American family, which was the vehicle for progress. Whether their fiction specifically commented on the frontier or not, the virtues that came to be associated with the West and frontier sentimentalism became embedded in the literary formation of a distinct American identity. Nineteenth-century women increasingly began defining themselves and their reality through the lens of this sentimental ideal of the self-sufficient and capable woman. This ideal, then, did not solely exist in a fictional world; women increasingly began living by this code of virtues to the best of their abilities and encouraged others to do the same through another acceptable genre of literature for them: advice literature. 


\section{CHAPTER III: A CURE FOR CORRUPTION: FRONTIER VIRTUE AND WOMEN'S}

\section{ADVICE LITERATURE}

This chapter will examine how eastern women's advice literature encouraged other Americans to emulate the simpler, republican virtues associated with rural areas-and later the frontier. While the frontier had been a concept in American culture since the eighteenth century, it intensified in the 1830s. Rural areas increasingly became the embodiment of the republican ideal in contrast to rising urbanization. The rise of market capitalism in eastern urban centers fostered great fears among nineteenth-century Americans that the foundation may be crumbling, and capitalist self-interest would overtake virtuous patriotism, rooted in republicanism. As the nation expanded, the West became the new repository for rural ideals and came to embody the virtuous roots of America - it hearkened back to an idealized and simpler time of industry, selfregulation, and self-sufficiency over self-indulgence, greed, and self-interest. Thus, the Western frontier came to symbolize American patriotism and republican virtue amid larger anxieties of capitalist urban development in the 1830s and throughout the nineteenth century.

The antebellum era in America saw numerous changes that made many uncomfortable. Alexander Hamilton's capitalist vision, which caused many a suspicious eye upon him in the Revolutionary era, was posthumously coming to fruition. Aggressive masculinity came to define the public and political arena in the so-called Age of Jackson. This competitive masculinity was epitomized in image of the industrialized urban machine, which stood in contrast to the pastoral ideal of the past. As Leo Marx described it in his 1964, classic book, The Machine in the Garden, "the machine carried with it a sudden, shocking intruder upon a fantasy of idyllic satisfaction. It invariably is associated with crude, masculine aggressiveness in contrast with the tender, feminine, and submissive attitudes traditionally attached to the landscape." If those who 
advocated the Hamiltonian capitalist industrial vision wanted it to be successful, it had to be adapted to American republican values and justified somehow. Those who shared this vision acknowledged that, as Marx wrote, "Americans would be more likely to endorse the Hamiltonian program with enthusiasm if permitted to conceive of it as a means of fulfilling the pastoral ideal." 67

The pastoral ideal emerged as a form of literary escapism for many urban Americans in the nineteenth century as a response to the contradictory cultural, political, and economic developments that threatened the nation's very republican character. The pastoral ideal sentimentalized the rural world as a means to cling to the nation's virtuous simple foundations in response to intense social change and turmoil. The pastoral ideal, as Anne C. Rose writes, "served as a sort of leavening for urban culture, not reversing social changes but making them bearable." With the rise of very populated urban centers across the eastern seaboard and a coherent culture forming around market capitalism, many Americans felt torn about their nation's identity. Cities left more room for the ambitions of hardworking industrious men at the same time they stratified class divisions. As Rose asserts, the "rise of cities and their problems of poverty, crowdedness, and crime threatened to upset the nation's self-image as a garden in the wilderness...the personal anonymity of a mobile, mass society made Americans worry about the emotional detachment and social disorder threatened by the decline of traditional community life." 68

The pastoral ideal was a set of idealized representations about the rural countryside, but its virtues were readily applied the American West, creating what I have found to be a new form

\footnotetext{
${ }^{67}$ Leo Marx, The Machine in the Garden: Technology and the Pastoral Ideal in America (New York: Oxford University Press, 1964), 29, 168-169.

${ }^{68}$. Rose, Voices of the Marketplace, 61, 66.
} 
of sentimentalism - frontier sentimentalism. The western frontier, then, was more than just a geographic boundary - it was the solution to the problems and tensions that urbanization and capitalism presented. As Greg Grandin has pointed out, "Facing west meant facing the Promised Land, an Edenic utopia where the American as the new Adam could imagine himself free from nature's limits, society's burdens, and history's ambiguities." ${ }^{99}$ Thus, the frontier was an idyllic paradise that could save America from the conflicts that came from modernizing, and it was being cemented into American culture as such.

Women were at the heart of the pastoral ideal and, subsequently, of frontier sentimentalism. As the industrialized machine came to be associated with masculine aggressiveness, women were the soft "civilizers" of the clean rural landscape-women's perceived innate virtue and inherent emotionality that sentimental culture attributed to them made them the natural fit for this role. The pastoral family farm culture, as Susan Sessions Rugh asserts, "became a means to resolve the contradictions between the family and the market, community and individualism, tradition and transformation." ${ }^{, 70}$ Nineteenth century women were already at the heart of sentimental culture and expected to be moral pillars of the republic. This ideal was a racialized concept, however, as only white women were assigned these moral duties. The racist tones of traditional sentimentalism were carried out West as well, where frontier sentimentalism only applied to white women, who served as the harbingers of republican "civilization."

Through domestic advice literature that encompassed essays and books on fashion and housekeeping, women encouraged the adaptation of sentimentalized frontier qualities into larger

\footnotetext{
${ }^{69}$ Grandin, The End of the Myth, 2.

${ }^{70}$ Susan Sessions Rugh, Our Common Country: Family Farming, Culture, and Community in the NineteenthCentury Midwest (Bloomington: University of Indiana Press, 2001), xvi.
} 
American culture. Through this, women in the East pushed the idealized rural virtues into the mainstream, and therefore into American identity; though they may have been perceived as living on the domestic periphery of society separated from the public sphere, they were far from it. Nineteenth century women were disseminating new standards of behavior that were distinctly American through their advice literature, contributing significantly to how the nation perceived itself. Advice literature was sentimental because it provided real-life applications to structuring one's life around sentimental virtues, disseminating moral lessons on the importance of maintaining purity through republican simplicity and good economy in the home and cultivating sincere virtues through simpler fashion.

Popular publications such as Godey's Lady's Book urged women to emulate the sentimental virtues associated with the pastoral ideal - the romanticized simplicity and beauty of nature joined with the idealization of the hardworking yet modest life in the country-through the advice they disseminated on simplicity through fashion, the household, and gardens. Nineteenth-century family life, education, and religion all took place in what Laurel Thatcher Ulrich deems the "economy of homespun." ${ }^{71}$ In the early nineteenth century, as Ulrich points out, the focus remained on the female-centric, homespun economy as the basis of character. Attributing virtue to household production allowed Americans to reconcile the expanding market with republican virtue. By being industrious and making products themselves, women could help ensure that their families relied on the household matriarch rather than outside markets. Household production made women private manufacturers, and the rhetorical value assigned to the homespun economy protected women's virtue from the corrupting power of the public

\footnotetext{
${ }^{71}$ Ulrich, Laurel Thatcher. The Age of Homespun: Objects and Stories in the Creation of an American Myth. New York: Vintage Books, 2002.
} 
sphere. In the early half of the nineteenth century, as Ulrich writes, "images of industrious, selfsacrificing, and patriotic women domesticated and softened the often harsh realities of political conflict, economic uncertainty, and war." ${ }^{72}$ With the monumental developments of the nineteenth century, women's domestic production further served to protect their virtue as well as American patriotism and character. As preservers of republican virtue, this rural homespun ideal particularly applied to western frontier women.

Popular nineteenth century women's periodicals like Godey's Lady's Book venerated virtuous rural and frontier women while, at the same time, they advertised elegant Europeaninfluenced fashions. Notorious for its fashion plates, Godey's prominently displayed women adorned in elegant clothing for its audience consisting mostly of middle-class and elite white women along the east coast. The popular women's magazine promoted the latest fashions in London and showcased images of the adorned queens of Europe, despite the fact that the aristocracy was an un-republican institution.

${ }^{72}$ Ulrich, The Age of Homespun, 413. 


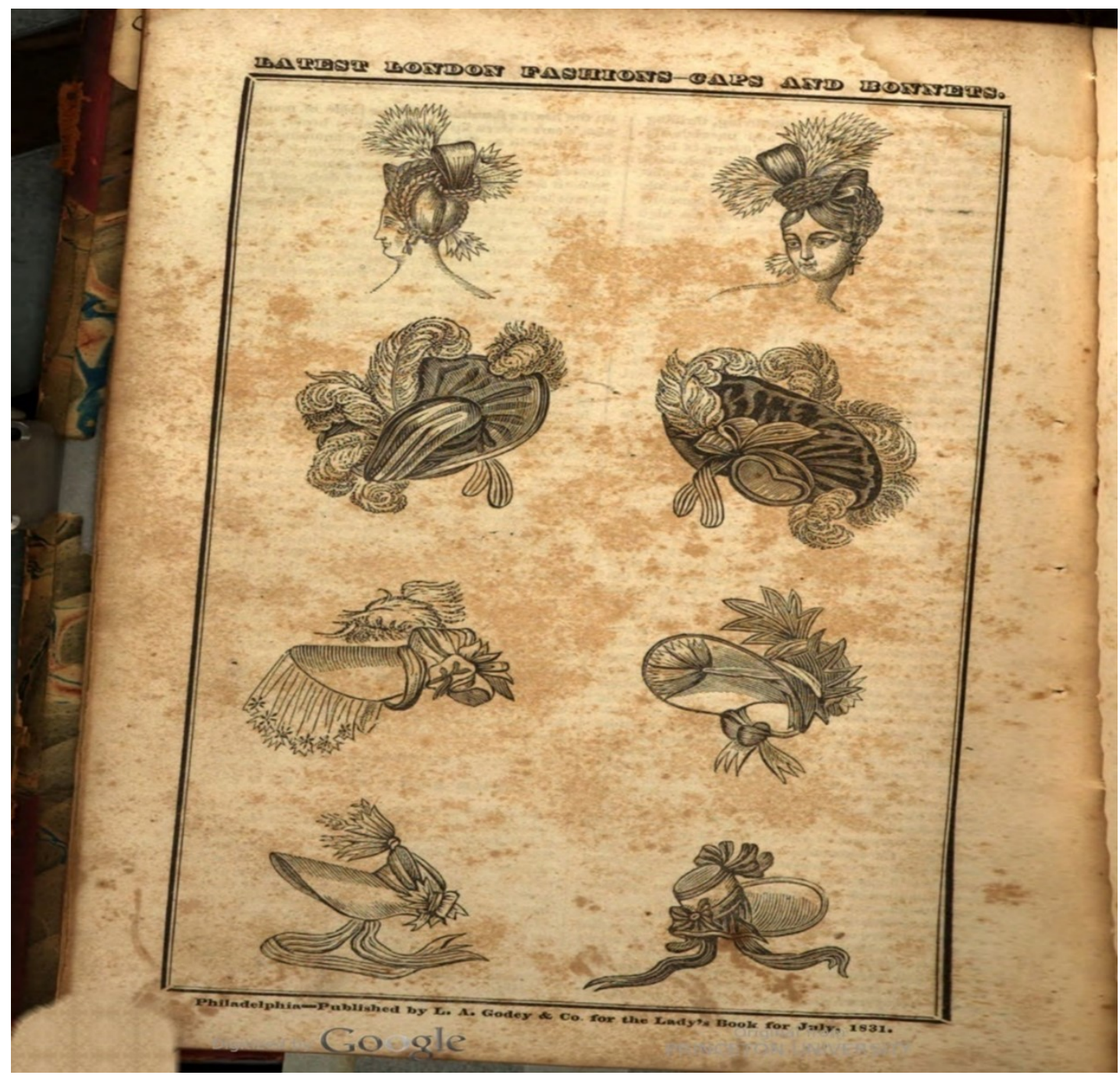

Figure 1: London's Latest Fashions-Caps and Bonnets, c. 1831. LA Godey \& Co. ${ }^{73}$

${ }^{73}$ L.A. Godey \& Co., "The Latest London Fashions-Caps and Bonnets," Godey's Lady's Book, 3 (July 1831): 8. https://hdl.handle.net/2027/njp.32101064241894? urlappend=\%3Bseq $=18$. 


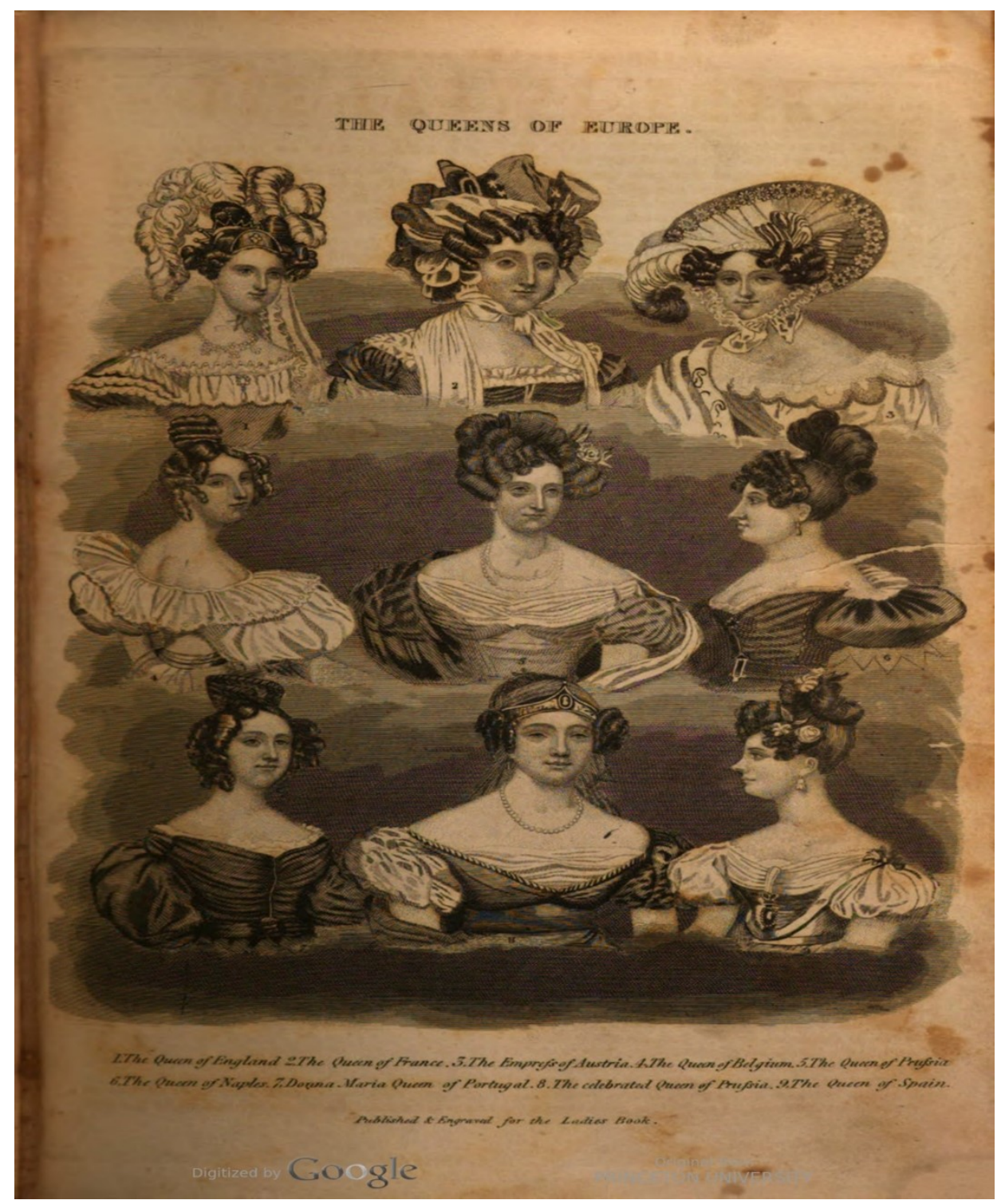

Figure 2: "The Queens of Europe" c. 1836, L.A. Godey \& Co. ${ }^{74}$

While publications such as Godey's looked at European fashion trends and encouraged readers to stay up to date, there was an awareness that what they were showcasing was antithetical to republicanism. Aristocratic fashion was perceived as vain and shallow; it inhibited the cultivation of inner virtue with its vain self-obsession about appearance and masked the

\footnotetext{
74 “The Queens of Europe,” Godey's Lady's Book, 12 (January 1836): 3. https://hdl.handle.net/2027/njp.32101064242066? urlappend=\%3Bseq=19
} 
expression of one's truest sentimental self under layers of finery. Since middle-class society was viewed as the backbone of American virtue and morality, if women bought into the hypocrisy of fashion, they were threatening the very foundation of the republic. Yet, even though aristocratic fashion was frowned upon, Godey's displayed aristocratic women on its pages because good taste was still valued. The refined taste that most middle-class Americans sought to cultivate through fashion had European, aristocratic roots, so European fashion trends were still showcased. The line between refined taste and problematic aristocratic fashion, however, was blurry. ${ }^{75}$ The popular ladies' magazine resolved this problem by coupling the latest fashion trends with lessons on republican virtue, creating a uniquely American fashion-republican fashion.

\footnotetext{
${ }^{75}$ Halttunen, Confidence Men and Painted Women, 70.
} 


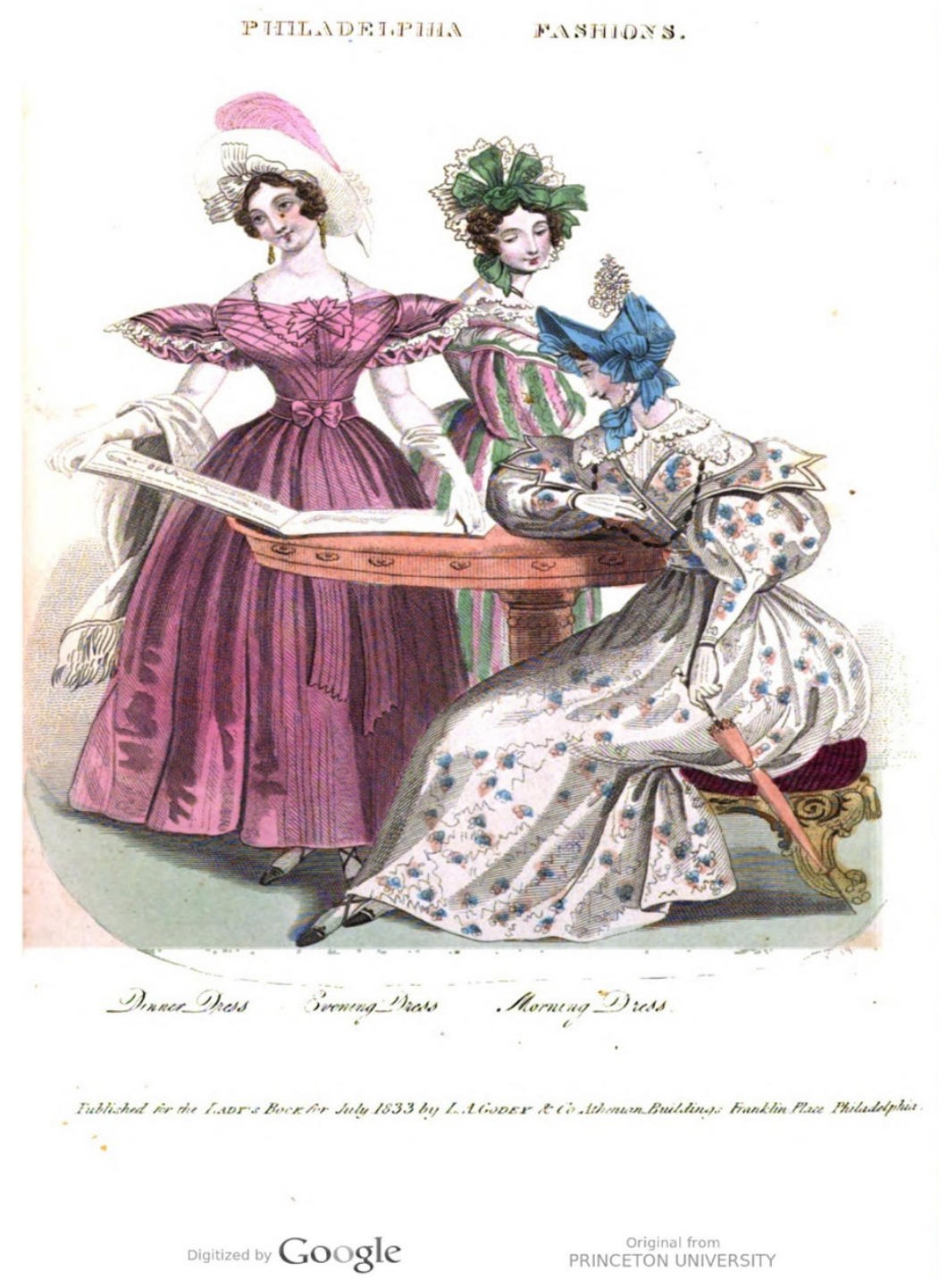

Figure 3: Philadelphia Fashions, c. 1833. LA Godey \& Co. ${ }^{76}$

Sentimental writers issued warnings about the failings of the "fashionable woman," implying that she needed to be brought to her senses. Their solution lay in genteel fashion, both refined and virtuous. Gentility was a primarily middle-class code of behaviors that focused on

${ }^{76}$ L.A. Godey\& Co., "Philadelphia Fashions," Godey's Lady's Book and Magazine, 7, (July 1833): https://hdl.handle.net/2027/njp.32101064241860?urlappend=\%3Bseq=10. 
one's clean appearance, good manners, and etiquette. Richard L. Bushman describes gentility as a "self-aware performance" that emerged "naturally as a result of adopting genteel standards of behavior to elevate human life. People were instructed in a hundred details of how to dress, hold their bodies, and converse, all for the purposes of becoming more pleasing." Like fashion, gentility had aristocratic origins, but it, too, was democratized in the name of republicanism in the eighteenth and nineteenth centuries; as it became an American cultural mode that dictated white middle-class behavior, especially in the antebellum era, it "offered the hope that anyone, however poor or however undignified their work, could become middle-class by disciplining themselves and adopting a few outward forms of genteel living." $" 77$ Thus, in nineteenth-century America, republicanism became the universal standard for reconciling behaviors of aristocratic origin to a democratic age; the world of refinement and fashion was no longer anti-republican if anyone could achieve it through industry and perseverance, that is, republican virtue.

Even though gentility was primarily a public performance, nineteenth-century Americans did not see it as disingenuous, for they believed that refinement and beauty meant that one's truest, best qualities were put on display. Appearance was still valued, but the true purpose of it was to highlight inner qualities that made one's sentimental self apparent. Godey's reconciled republican virtue and aristocratic-inspired fashion hypocrisy by showcasing trendy, Europeaninspired fashions alongside narratives of simple sentimental beauty. The magazine, and others like it, published many stories idealizing patriotic women who adhered to notions of republican virtue, encouraging women to showcase their true beauty through sincerity. For instance, a contribution in Godey's from 1831 titled "True Beauty," states, "It is a low and degrading idea of

\footnotetext{
${ }^{77}$ Richard L. Bushman, The Refinement of America: Persons, Houses, Cities (New York: Vintage Books, 1993), xiv, xvi.
} 
that sex, which was created to refine the joys, and soften the cares of humanity, by the most agreeable participation, to consider them merely as objects of sight. This is abridging them of their natural extent of power, to put them on a level with their pictures." Emphasizing that a woman's true beauty comes from virtuous qualities inside and not outward vanity, the contribution continues:

How faint and spiritless are the charms of a coquette, when compared with the real loveliness of innocence, piety, good humour, and truth; virtues which add a new softness to sex, and even beautify beauty! That agreeableness, which must have otherwise appeared in the modest virgin, is now preserved in the tender mother, the prudent friend, and the faithful wife... she who takes no care to add to the natural graces of the person any excellent qualities may be allowed still to amuse as a picture, but not to triumph as a beauty. ${ }^{78}$

In this sense, Godey's is defining beauty in terms of female republican virtue- beauty is inherent in the caring and nurturing mother, the dedicated friend, the dutiful wife - a woman who preserves virtue in her home and also ensures that her female networks are doing the same.

Commentators on refinement were careful to make it clear that gentility could spread through the ranks of even the lowliest individuals, including rural women in the eastern countryside, and presumably even pioneer women on the western frontier. Rural women's simplicity was seen as more inherently beautiful and countered the genteel inclination toward aristocratic enjoyments. The fashionable woman was reminded to not let fashion take over her virtue, as Bushman points out, "Their simple country girls, with no education, often managed to

78 “True Beauty," Godey's Lady's Book, 2 (January 1831): 199, https://hdl.handle.net/2027/njp.32101064241902? urlappend=\%3Bseq=211. 
outshine the belles of the ball." ${ }^{79}$ Frontier sentimentalism thus served to resolve some contradictions inherent in the fashionable woman of the nineteenth century.

Godey's also encouraged economy in interior design to uphold domestic virtue, as did most reputable nineteenth-century publications directed at women. An 1836 issue outlined marital expectations for republican women in a contribution titled "Domestic Duties," which advised new wives to be sincere, even-tempered, and self-sacrificing. This article also counseled women to, without taking the lead in their household, "cultivate in herself, and to encourage in her husband, rational domestic tastes... She has to proportion the whole expenditure of her household, to the income which she is now to command; and in this part of her duty there is often exercise for self-denial as well as for judgment." 80 If the world of fashion was hypocritical, a parlor that was adorned with ostentatious pieces that were not domestically produced threatened to surrender the household over to the specter of corruption looming overhead in the public market. A true republican woman looking to uphold the virtue of the nation encouraged rational consumption, and practiced self-denial when it came to unnecessary consumption of material goods.

Another popular form of women's literature that disseminated virtuous republican character took the form of domestic advice manuals, which focused on household management. While ladies' magazines could advocate for republican womanhood, domestic help manuals gave women more tangible and extended means for structuring their lives around these virtues they were expected to uphold. A virtuous household was the foundation of a respectable family which, in turn produced morally upstanding American citizens, so good housekeeping was an

\footnotetext{
${ }^{79}$ Bushman, Refinement of America, 307, 315.

80 “Domestic Duties," Godey's Lady's Book, 12 (January 1836): 6, https://hdl.handle.net/2027/njp.32101064242066? urlappend $=\% 3$ Bseq $=24$
} 
ideal that middle-class women upheld, and less elite women aspired to. Ladies producing domestic help books, such as Lydia Maria Child and Catherine Beecher, were often women of means. But they encouraged economy and frugality in their domestic help literature.

Beecher's A Treatise on Domestic Economy, published in 1858, emphatically encouraged women to take on their domestic duties because a woman's labor was the very thing that kept American democracy afloat. If women failed their domestic duties, the nation would descend into tyranny and the republic would fail. For in Beecher's words:

The mother forms the character of the future man; the sister bends the fibres [sic.] that are hereafter to be the forest tree; the wife sways the heart, whose energies may turn for good or for evil the destinies of a nation. Let the women of a country be virtuous and intelligent, and the men will certainly be the same. The proper education of a man decided the welfare of an individual; but educate a woman, and the interests of a whole family are secured. ${ }^{81}$

By linking women's duties directly with republican virtue, Beecher affirmed the essential nature of women's roles. While not explicitly referencing frontierswomen, Beecher also touched on why women were so essential to frontier migration. Westward expansion was associated with masculine values of enterprise and individualism; women balanced these values out and preserved republican virtue by keeping men in line and making sure individual enterprise did not corrupt them. Intelligent men may have forged opportunities for America's democratic republic to expand and thrive, but women were the preservers of the very fabric of the nation's identity. For it was their duties, their labors and industry that preserved the collective virtue and success of the republic.

\footnotetext{
${ }^{81}$ Catharine Beecher, A Treatise on Domestic Economy for the Use of Young Ladies at Home and at School, $3^{\text {rd }}$ rev. ed. (New York: Harper and Brothers, 1858). In Ruth Barnes Moynihan, Cynthia Russett, and Laurie Crumpacker, eds., Second to None: A Documentary History of American Women, Volume I: From the $16^{\text {th }}$ Century to 1865 , (Lincoln: University of Nebraska Press, 1993), 243.
} 
While Beecher promoted women's labor and industry, she sometimes made assumptions in her work. For instance, while giving advice on washing the laundry, she assumed her audience would have what was primarily a middle-class luxury—domestic servants. As Beecher states, "If the mistress of the family requires the washerwoman to notify her when she is through, and then ascertains if all these articles are put in their places, it will prove useful." ${ }^{\prime 2}$ While domestic servants did not detract from republican virtue in the eyes of women like Beecher (they merely made attaining this ideal more convenient), her reference to them reveals whom she assumes her audience is: an eastern seaboard-based one like her home in New York, where servants were more common. While some families in the western frontier did have domestic servants, many did not set out with them, nor could they afford such a convenience, especially after first arriving to the new setting. Therefore, while Beecher's domestic treatise does promote republican virtue to her readers, it carries a modicum of inaccessibility to frontier readers who might not have the same resources as a woman in an eastern urban setting.

Lydia Maria Child's 1833 work, American Frugal Housewife, catered to a wider audience. Child, based in Massachusetts, wrote in a way that was accessible to her sisters in the East as well as in the West. Child's domestic literature encouraged some qualities attributed to the pastoral ideal and sentimentalized frontier women, encouraging all American women to live simply like the strong yet virtuous frontierswomen, who lived lives that would make patriotic Revolutionary-era women proud.

The most pressing sentiment in Child's domestic treatise is an anxiety for the future of the republic. Concerned with the hypocrisy of the fashionable world of the nineteenth century,

\footnotetext{
${ }^{82}$ Beecher, A Treatise on Domestic Economy, in Second to None, 212.
} 
she warns that: "Gentility and taste are always lovely in all situations. But good things, carried to excess are often productive of bad consequences. When accomplishments and dress interfere with the duties and permanent happiness of life, they are unjustifiable and displeasing; but when there is a solid foundation of mind and heart, all those elegancies are but becoming ornaments. ${ }^{83}$ If the world of fashion interfered with republican virtue, it ceased to be fashion and was not justifiable anymore. Any fashion that hid a woman's true sentimental character underneath excessive ornamentation was not republican fashion.

Child feared that the virtuous republican household of the Revolutionary era was ceasing to exist, and that the habits of prior patriotic generations were being tossed out, leading to a decay of virtue. Child laments: "The good old home habits of our ancestors are breaking up—it will be well if our virtue and our freedom do not follow them!" Addressing readers who would not take her seriously, she states, "It is easy to laugh at such prognostics, — and we are well aware that the virtue we preach is almost obsolete, — but let any reflecting mind inquire how decay has begun in all republics, and then let themselves whether we are in no danger, in departing thus rapidly from the simplicity and industry from our forefathers." Furthermore, if American households did not emulate the industry, economy, and simplicity of their predecessors, the very future of patriotic republican freedom was at stake. For a luxurious republic, in Child's mind, could not be a virtuous one: "A luxurious and idle republic! Look at the phrase! - The words were never made to be married together; every body [sic] sees it would be death to one of them." 84

\footnotetext{
${ }^{83}$ Lydia Maria Child, The American Frugal Housewife (Boston: Carter, Hendee, and Co., 1833 ), 93.

${ }^{84}$ Child, The American Frugal Housewife, 99.
} 
Child's solution to counter this potential declension narrative is simple: emulating the simple republicanism practiced by the patriotic founding generation. In her domestic treatise, Child hearkens back to the republican simplicity of the independent yeomanry, unsurprisingly tying them to the foundation of American character and virtue. Praising industrious farmers and warning the emerging unsavory classes of swindlers in urban environments, Child states that:

However, it is not our farmers who are in danger of this species of extravagance; for we look to that class of people, as the strongest hold of republican simplicity, industry, and virtue. It is from adventurers, swindlers, and broken down [sic] traders, - all that rapidly increasing class of idlers, too genteel to work, and too proud to beg, - that we have most reason to dread examples of extravagance. ${ }^{85}$

Attributing the highest character to agrarian farmers, Child makes a plea to her fellow Americans to emulate the virtue inherent in the pastoral ideal. In her influential position, she admonishes the "class of idlers" who do not practice good economy, simplicity, and are too concerned with gentility and appearance that they threaten to undermine the nation's character. Those who do not work hard and are only concerned with extravagance over character are, in Child's view, the foundation of the dangers facing American republican character in the nineteenth century. This pastoral ideal, then, was further projected onto the western frontier as the nation expanded.

For these reasons, as her title suggests, Child urged women to practice economy and not over-indulge in frivolity. Much like the qualities attributed to her rural women, Child advises "Self-denial, in proportion, to the narrowness of your income, will eventually be the happiest and most respectable course for you and yours. If you are prosperous, perseverance and industry will

${ }^{85}$ Child, The American Frugal Housewife, 102. 
not fail to place you in such a situation as your ambition covets..." ${ }^{86}$ Much like the conditions frontierswomen faced when leaving the comforts of their eastern homes to live in the wilderness, Child encourages all women to practice these characteristics, as "self-denial," along with "perseverance and industry," are characteristics that lead to respectability.

Child also recommends that women cease being ashamed of economy and frugality and counsels them to guide their husbands to do the same. Imagining women as the moral foundations of their households, Child asks them to reform their husbands if needed, to "Let their husbands and fathers see them happy without finery, and if their husbands and fathers have (as is often the case) a foolish pride in seeing them decorated, let them gradually check this feeling by showing them that they have better and surer means of commanding respect." Husbands and fathers, then, were also supposed to practice frugality and not adorn their wives and daughters in finery, but it was the woman's obligation to check these impulses within the men in their lives. Women were the ones who had to encourage virtue, reject ostentatious finery, and restrain their husbands' desire to show off status by giving their wives unnecessary objects in order to serve as the familial foundation of virtuous economy. They had to guide their husbands and fathers and remind them that "by exertion of ingenuity and economy, ... neatness, good taste, and gentility, are attainable without great expense." 87

The cult of true womanhood, a term coined by historian Barbara Welter, was an idealization of femininity, based on a standard of virtues that a woman was expected to uphold. True womanhood emphasized women's domestic roles as wives and mothers and exalted their innate purity, assigning them the role of preserving republican virtue and, in turn, American

\footnotetext{
${ }^{86}$ Child, The American Frugal Housewife, 5.
}

${ }^{87}$ Child, The American Frugal Housewife, 6. 
identity ${ }^{88}$ The cult of true womanhood placed women on a domestic pedestal and sentimentalized them, with women's innate emotionality serving as the source of their virtue. Middle-class white women were supposed to counter capitalist developments in the public sphere by cultivating domestic virtues such as those Child encouraged of good taste, economy, and self-sufficiency. Nancy Cott, one of the first historians to articulate the ideology of separate spheres, noted that domestic authors "denigrated business and politics as arenas of selfishness, exertion, embarrassment, and degradation of the soul." Therefore, it was a woman's duty to perform moral maintenance in the home. As Cott also points out, the cult of domesticity was intended to "implant, in the family, social control of a kind that seemed necessary and appropriate in a democratic republic." 89

Rural women, and by extension, their frontier counterparts, not only epitomized republican virtues, but also this domestic ideal of femininity. They adhered to the economy and self-sufficiency of the founding generation out of necessity and because they placed stock in the values and attributes of frontier sentimentalism. In contrast to their urban counterparts, rural women were imagined as even more resilient and self-sufficient than urban women. Domestic authors like Child encouraged eastern women to emulate them with good economy. City women, in particular, had to be warned not to be led astray by the world of fashion and corruption. Pushing back against those who thought they were above practicing good economy, Child challenged any notions that frugality was antithetical to virtue, arguing that nothing could be further from the truth. Child advocated that "True economy is a careful treasurer in the service of benevolence; and where they are united respectability, prosperity and peace will follow." Good

\footnotetext{
${ }^{88}$ Barbara Welter, "The Cult of True Womanhood: 1820-1860." American Quarterly 18, no. 2 (1966): 151-74. doi: $10.2307 / 2711179$.

${ }^{89}$ Nancy F. Cott, The Bonds of Womanhood: “Woman's Sphere” in New England, 1780-1835 (Yale University Press, 1977), 67, 94.
} 
economy was again tied to a virtuous and patriotic household. The household was the foundation of American character and republican virtue since it is what produced pious citizens. It was imperative, then, as Child emphasized, to practice good economy to not corrupt that foundation.

A lack of economy even had potential to ruin marriages and the familial foundation. Child tells a cautionary tale of a farmer's daughter who married a destitute young physician. Her father gave her two thousand dollars upon their marriage, but she insisted on spending this money on frivolous items to adorn their house. The woman kept lavishly consuming rather than practicing good economy, and her husband was made irritable by want of money and his wife's lavish spending, causing unnecessary tension in their marriage. Child imparts her lesson in this instance by advocating "Did the doctor gain any patients, or she a single friend, by offering their visitors water in richly-cut glass tumblers, or serving them with costly damask napkins, instead of plain soft towels? No; their foolish vanity made them less happy, and no more respectable."90 Hence, unnecessary and lavish consumption did not serve to make husband or wife happier or more respectable, but it did threaten to undermine familial virtue.

In one of her closing lessons in The American Frugal Housewife, Child reminds her readers that those of true moral courage wish to be respected for good taste and manners over extravagance. She also advises women in the East to practice some qualities of frontier sentimentalism such as resilience, strength, and self-sufficiency to deal with any misfortune and avoid becoming destitute. She tells the true story of an unfortunate unnamed woman who lost her uncle, aunt, and husband, which left her destitute. Rather than resigning herself to her fate, however, she "supported herself comfortably by her own exertions, and retained the respect and

\footnotetext{
${ }^{90}$ Child, The American Frugal Housewife, 90.
} 
admiration of a large circle of friends." She was able to remain happy and respectable by being industrious and self-sufficient. Her misfortune, however, was not over, as her house caught fire and she had to jump from her window, causing her right arm to need amputation and her right leg to become useless. Her friends were very kind and helped this respected woman, and "for a short time she consented to live on their bounty; but, aware that the claims on private charity are very numerous, she with the genuine independence of a strong mind, resolved to avail herself of the public provision for the helpless poor." ${ }^{91}$ Clearly expressing concern about growing poverty in cities, Child credits this poor woman for her courageous resolve and industrious fortitude. Thus, Child uses frontier sentimentalism to urge women to make their cities more virtuous by emulating the moral courage and strong minds of their sisters in the countryside.

Child was not the only one advocating the pastoral republican ideal—Godey's associated the republican virtue of rural women with their proximity to nature, believing this environment a natural condition for building a respectable life of industry and economy. "The Editor's Table" from an 1857 issue specifically addressed women of the West, illustrating how "the belle of some western prairie - would she not prefer a sparkling jewel, though of paste, on her bosom to the lily-of-the-valley, even though this exceeded in beauty the ornaments of Solomon? And why? Because jewels cost money, and flowers may be had for the gathering." Implying that the proximity to nature for pioneer women made simplicity and virtue more inherent, the piece continues, "We are slow to learn that in simplicity and appropriateness is the best ideal for the beautiful and noble. The women of the West are no more faulty in this respect than their sisters of the eastern cities; only the former lose more pleasures by attempting to be fashionable when it would be so very easy to be happy in spite of the fashion." In this comparison, Godey's asked

${ }^{91}$ Child, The American Frugal Housewife, 112. 
western readers to take advantage of the natural wealth around them. It also urged eastern readers to be more like their sisters in the West; to find their beauty in simplicity and in the beauty around them, rather than trying to be fashionable constantly. For, as the magazine cautions, "Jewels may be most regal, but flowers are the most natural adornments of the young, and therefore most lovable." 92

Aside from just advocating for republican virtue, Child appeared to have adhered to the tenets of simplicity she laid out in her domestic treatise. Her personal letters show a woman dedicated to the virtuous ideals she espoused in her public literary career. In an 1831 letter to an unidentified recipient, Child records a vacation where the "uniform is very simple-Merely a straw bonnet of any kind, trimmed with blue, and light blue calico gowns of any figure you choose. White gowns, or any light gowns a young lady may happen to have occasionally worn; it is merely preferred that all dresses should be plain and simple. ${ }^{.93}$ In this instance, Child echoed the simple fashions of her frontier sisters, and shows her dedication to simplicity over elegance.

Child herself lived out the pastoral ideal when in 1836, she lived in West Boylston and Northampton, in the Massachusetts countryside. In a letter to Louisa Gilman Loring, Child romanticized the countryside as she described her house in the woods:

You have no idea the exceeding beauty of the country here. The apple and cherry trees have been abundantly covered with blossoms, that they looked as if a white were entirely spread over their green foliage. The petals are now falling on the grass so plentifully, that the fields seem covered with snow. The little birds are so familiar that they come pecking at the windows, and hopping across our door steps [sic] One little sparrow now attending

\footnotetext{
92 "Editors' Table.: A Young Lady's Ideas of Western Life. Reply to the Wish of a Young Lady. Places of Education for Young Women." Godey's Lady's Book and Magazine 5, (1857): 465, http://libproxy.lib.ilstu.edu/login?url=https://www-proquestcom.libproxy.lib.ilstu.edu/docview/126089174? accountid=11578.

93 "Mrs. D.L. Child [Lydia Maria Child] ALS to Unidentified, April 18, 1831," in Lydia Maria Child Papers, Clements Library, University of Michigan, http://quod.lib.umich.edu/c/child/child.0001.001/1.
} 
to her family cares, in her snug little ground-nest, is so accustomed to our visits, that she scarcely takes the trouble to move, when we are near enough to lay hands on her. ${ }^{94}$

She reveled in her simplistic life and the beauty of the natural landscape surrounding her. She loved the virtuous independence of prior generations of republican Americans so much that in the same letter she writes, "If it is in God's will, I hope never again to abide in the cities. I do so love a close intimacy with scenes like these." 95 For concerned republican women like Child, the sentimentalized ideals in pastoralism and frontier women were ones to live up to.

Godey's also echoed the pastoral republican values Child promoted in her writings, urging women to take advantage of their surroundings. A piece contributed by London Magazine urged ladies in rural settings to devote a significant portion of their day to garden work "for health's sake." There was a notion in nineteenth century America that going out into rural areas with an abundance of nature was good for one's health, since the pastoral setting was viewed as a clean, healthy, and virtuous setting compared to the crowded, polluted, and vice-ridden cities. Godey's drew upon this idea and adapted the advice it gave to frontierswomen to urban women. This 1831 issue also gave advice to women on watering gardens, stating that for a healthy young woman, the practice would "add greatly to the strength of her constitution, and the tranquility of her nights." In this instance, plants were also tied to women's virtuous industry, as the principle of keeping a healthy garden is for "something to be taken care of, and to care for and depend upon us; something that requires labour, the beginning and end of all improvement and

\footnotetext{
94 “[Lydia] Maria [Child] ALS to Louisa [Gilman Loring], May 30, 1836,” in Lydia Maria Child Papers, Clements Library, University of Michigan, http:/quod.lib.umich.edu/c/child/child.0001.003/1.

95 “[Lydia] Maria [Child] ALS to Louisa [Gilman Loring], May 30, 1836," in Lydia Maria Child Papers, Clements Library, University of Michigan, http://quod.lib.umich.edu/c/child/child.0001.003/1.
} 
enjoyment. ${ }^{" 96}$ Gardening, therefore, was viewed as part of women's roles that not only contributed to notions of republican industry tied to the West, but fostered the inherent nurturing qualities attributed to women that made them more virtuous.

The ideals of rural simplicity, clearly prevalent in nineteenth-century American consciousness, ultimately came to be projected onto frontier women themselves. An occasional pastime of nineteenth-century northeastern Americans was to travel West and observe the unfolding frontier. Oftentimes, women were a source of commentary, and were sometimes compared to their sisters on the eastern seaboard. For instance, an 1877 Harper's Bazaar article noted that it is apparent to travelers that the women on "almost any frontier are a vastly superior order of women to the great generality," and that they "shine beside their city sisters with an enviable lustre [sic]" (This example illustrates that frontier ideals persisted into the postbellum era). In this case, Harper's Bazaar criticized eastern gentility and frivolity and any notions of superiority any easterners had toward the West while also praising the resourcefulness of the frontier people. City folk may have dressed fashionably or played piano well, but: "To offset these superficial advantages of ours what have they? They can fire a rifle and hit with the shot; they can dress a wound; they can saddle a horse and ride him; they can face a wilderness and supply themselves with civilization out of their own resources. While we flutter round the flowers and enjoy ourselves, they conquer all the stern realities of life, and found States and peoples." ${ }^{.97}$ Harper's Bazaar appears to be echoing the prevailing urban anxieties of the time here, as the publication warns city dwellers about being too concerned with superficiality rather than cultivating useful and resourceful skills. In cultivating a patriotic, resourceful, and self-

\footnotetext{
${ }^{96}$ London Magazine, "Garden Operations for Ladies," Godey’s Lady’s Book, 3 (July 1831): 10, https://hdl.handle.net/2027/njp.32101064241894?urlappend=\%3Bseq=20.

97 "Frontier Women." Harper's Bazaar (1867-1912), Aug 11, 1877, 498, http://libproxy.lib.ilstu.edu/login?url=https://search.proquest.com/docview/125678442?accountid=11578.
} 
sufficient perception of the frontier, publications such as Harper's Bazaar cautioned residents of growing urban centers from straying too far from the virtuous character of their roots.

Observers writing for Harper's Bazaar also noted the strong minds of pioneer women, which allowed their virtuous character to shine because they were not corrupted by the world of fashion. "Their dress is often poor, but in those faces there is a vivid intellect as attractive as mere pink and white... As a rule, the minds of the women on the frontier are great and strong minds, well fed and constantly active," noted one account. ${ }^{98}$ While this publication expressed distaste for the fashion of frontier women, the mental fortitude and character they possessed blossomed in these observations. Noting character over dress, Harper's Bazaar adhered to the sentimental notion that a woman is truly beautiful because of her innate moral qualities - the "body charms because the soul is seen." ${ }^{99}$ Furthermore, frontier women were viewed as harbingers of sentimental culture because they were resourceful and strong, but also still gentle and virtuous.

As the frontier unfolded in the nineteenth century, Americans along the eastern seaboard certainly took note, with particular emphasis on how they believed that frontierswomen preserved the republican character of the nation. Whether they had been to the frontier themselves or read accounts from the West, observers presented idealized representations of westering women and began to adopt the new form of sentimentalism frontierswomen were fostering out West. What started out as a mere geographical boundary in the late eighteenthcentury Revolutionary world became embedded in American identity and consciousness as more families emigrated West and women did the work of cultural formation. As Grandin puts it, in

\footnotetext{
98 "Frontier Women." Harper's Bazaar (1867-1912), Aug 11, 1877, 498, http://libproxy.lib.ilstu.edu/login?url=https://search.proquest.com/docview/125678442?accountid=11578

${ }^{99}$ Halttunen, Confidence Men and Painted Women, 71.
} 
the nineteenth century, the frontier became a "state of mind, a cultural zone, a sociological term of comparison, a type of society, an adjective, a noun, a national myth, a disciplining mechanism, an abstraction, and an aspiration." 100 Through frontier sentimentalism, women embedded the republican pastoral virtues of the mythic West into American identity during a time when Americans were desperately searching for a reconciliation with what urban, industrial, capitalist America was becoming. The sentimental qualities of the frontier, however, did not merely appear in publications and advice literature - they were standards that frontierswomen migrating out West held themselves to. For women on the move in the nineteenth century, these ideals were a lived experience for them: a way in which they organized their reality in a new setting.

${ }^{100}$ Grandin, The End of the Myth, 116. 


\section{CHAPTER IV: LIVING THE IDEAL: FRONTIERSWOMEN MAKE FRONTIER SENTIMENTALISM THEIR REALITY}

Westering women on the move in the nineteenth century carried the values projected onto the frontier with them. This chapter examines how frontier sentimentalism was incorporated into frontierswomen's lived experiences throughout the century as they attempted to attain this ideal in their new homes. Americans imagined the West as the cradle of republican virtue and, through frontier sentimentalism, perceived frontier women as the embodiment of that virtue. Women who migrated to their frontier with their families were thus well aware of the ideals being projected onto them. Westering women willingly took on the roles prescribed to them by frontier sentimentalism, but not without conflict. They often came from the eastern seaboard, meaning their desire to adhere to the middle-class notions of taste did not simply vanish once they reached their new homes. These women still strongly associated nineteenth century womanhood and civilization with the East coast world of fashion and manners, or genteel refinement. ${ }^{101}$ In going into the wilderness, they were supposed to bring "civilization" to the West by living the virtues attributed to frontier sentimentalism. But those same virtues also required that they relinquish certain characteristics associated with "true womanhood": such as the world of high fashion and the "separate spheres" of domesticity and economic production. With westward settlement, they thus risked a loss of identity as "true women." Once they reached the West, pioneer women felt it was their duty to reconcile the demands of frontier life to the ideals of true womanhood expected of them in the East, no matter how they contradicted each other.

Frontierswomen's vital cultural role in the patriotic project of westward expansion had other inherent contradictions. Often attached to frontier sentimentalism was what Henry Nash

\footnotetext{
${ }^{101}$ See chapter one, pages 8-9.
} 
Smith called "the myth of the garden," a myth that "embraced a cluster of metaphors expressing fecundity, growth, increase, and blissful labor in the earth, all centering about the heroic figure of the idealized frontier farmer armed with that supreme agrarian weapon, the sacred plow." Yet, especially in the masculinized context within which Nash Smith examined the frontier, the myth of the garden went hand in hand with empire and conquest, legitimizing a "a doctrine of progress, of gigantic economic development, even though the myth of the garden at the same time implied a distrust of the outcome of progress in urbanization and industrialization." ${ }^{102}$ Nash Smith did not examine the essential role of frontierswomen, but white women were at the heart of this "doctrine of progress," even though that progress eventually expanded the very uncomfortable aspects of American culture they were supposed to counter. This "doctrine of progress" was conquest by another name, and white frontierswomen were complicit in it; that is, they were culturally implicated in Manifest Destiny through their prescribed roles.

While in the East, the frontier served an imagined repository of republican virtue where true equality ruled and there was no class stratification, it was, in fact, a real place. It comes as no surprise that westward expansion grew out of the capitalistic society that many nineteenthcentury Americans feared; the calls for enterprising men to follow the American Dream, that they can move West with their families and take pride in their hard labor "civilizing" the wilderness by bringing industry, technology, and markets to it. Yet, the hypermasculine, enterprising spirit of mobility and opportunity that was becoming a central component of American identity was also the cultural force behind industrialization and capitalist urban development in the East that was making so many uncomfortable. Since many of these westward

\footnotetext{
${ }^{102}$ Henry Nash Smith, Virgin Land: The American West as Symbol and Myth (Cambridge: Harvard University Press, 1950), 123, 187.
} 
emigrants were coming from this capitalist setting, it makes sense that, as Leo Marx pointed out, the raw landscape of the frontier was "an ideal setting for technological progress." With this, the American pastoral ideal had "lent itself to illusion from the beginning," for as the nineteenth century progressed, it "then had provided a clear sanction for the conquest of the wilderness, for improving upon raw nature and for economic and technological development--up to a point." 103 This, then, is where the crux of the essential nature of women on the frontier lies, for frontier sentimentalism, crafted by and filtered through women, reconciled masculine conquest with republican virtue.

Many historians have previously examined how the westward expansion afforded white women more opportunity and agency, which in turn contributed to nineteenth-century feminism. Yet, the cultural aspects of their roles in the west have not been studied. Frontierswomen were afforded more opportunity because of how they were sentimentalized in popular culture. Their heroic self-sacrifice for their families made them fit to preserve "civilization" in the "wilderness." In frontier sentimentalism, frontierswomen were the glue that held American republican culture together, even though that role became a cultural trap; western women gained more agency, but their only avenue to do so was within the capitalist patriarchy—-the very thing causing anxieties in the nineteenth century. With this, frontierswomen took prominent cultural representations of rural virtue and attempted to them a lived reality on the frontier.

From the outset of their migration, many women had to deal with internal conflicts, one of which was detachment from the home, which was supposed to be the cornerstone of their identities. Women preserved the foundation of republican virtue through their domestic efforts,

\footnotetext{
${ }^{103}$ Leo Marx, The Machine in the Garden: Technology and the Pastoral Ideal in America (New York: Oxford University Press, 1964), 203, 226.
} 
as they were responsible for cultivating respectable republican citizens. Yet migration west took her away from the home. As Susan Matt has pointed out, "ideals of feminine behavior did not always sit easily together, as women were supposed to be defined by the home but also willing to leave it." 104 Thus, frontierswomen had to build a new domestic haven in the West, bringing "civilization" and republican morality to the "untamed wilderness."

From the outset of their westward journey, women were put to the test by practicing the self-denial that made them sentimentalized heroines in the frontier context. Many frontierswomen, for instance, grappled with homesickness as they moved further away from the world they knew in the East. Nineteenth-century Americans associated westward expansion with American progress and the nation's economic and political development. As Matt points out, movement and migration were crucial aspects of Americans' identities in the nineteenth century. The masculine image of an individualistic and enterprising man moving West to fulfill his destiny became associated with the narrative of American success. Matt asserts that "the mythology of individualistic pioneers has been used to motivate successive generations to move on bravely and without hesitation." Yet, women, too were part of this individualistic ethos; they were supposed to embody moral fortitude. This mythology, however, overlooked the fact that "the pioneers themselves were homesick and hesitant, and that many hoped to - and sometimes did - return home." In other words, the ethos of rugged individualism associated with the frontier created a stigma around homesickness and obscured the emotional complexity of the process of migration. This was especially so for women.

\footnotetext{
${ }^{104}$ Susan J. Matt, Homesickness: An American History (New York: Oxford University Press, 2011), 8, 53.
} 
Despite the internal struggles they may have been experiencing, many women on the move felt a personal responsibility not to succumb to emotional weakness. Instead, they sought adopt the values of frontier sentimentalism, especially the self-denial practiced by the frontier heroines of popular literature. Emigrant women like Rebecca Burlend were conscious of the weight of what American culture placed on women, as she wrote that in her 1831 journey to Illinois, "Never before had I felt so much to devolve on me, and perhaps never in my life did I feel it my duty to practise self-denial.” While the Burlends were moving from England, Rebecca quickly felt the heaviness of what she frames as her duty-to fulfill the sentimentalized ideal of the pioneer woman. No matter how homesick she felt, she knew her duty was to not let it get the better of her; she was her family's foundation in this new country, and she had to remain strong and optimistic for them. Moving with her husband until they could send for the children, Burlend not only felt extra homesickness, but realized the emotional labor necessary for frontierswomen: "My native land was as dear to me as ever: my two children, whom I had bidden adieu, were strong ties. But the consciousness that it was my duty to bear up the sinking spirits of my partner, left me only one course to adopt." ${ }^{105}$ While Burlend was immigrating to America and the western frontier simultaneously, she still felt it her duty to internalize the virtuous qualities sentimentalized in pioneer women. In the republican landscape of the American pastoral vision, Burlend was aware of her lofty role and filtered her experience through this perspective.

Despite the homesickness they felt, frontierswomen were not completely isolated, as theybuilt new communities of support in their new homes. The family farm, as Mary Neth points out, "was not isolated, but part of a web of community ties that connected farms and families in

\footnotetext{
${ }^{105}$ Rebecca Burlend and Edward Burlend, A True Picture of Emigration, Edited by Milo Milton Quaife (Lincoln, NB: Bison Books, 1987), 13.
} 
rural neighborhoods. Farm people understood their lives through these social relationships, created by social interaction and by the labor that dominated their lives-farming." ${ }^{106}$ Women had long understood their lives through their relationships to others, and, as the harbingers of "civilization," they preserved a virtuous republic through these relationships: raising virtuous children, being a dutiful wife who made sure her husband was not corrupted by market society, and being a steadfast friend who helped their female networks uphold the same tenets of womanhood (and by association the nation's virtuous reputation). Out West, women's communities were crucial to adjusting to their new lives and navigating the new landscape.

Moreover, frontier life allowed women to uphold the virtuous homespun economy associated more with the region's perceived distance from urban capitalism. Keeping house was the hallmark of a respectable white woman in the nineteenth century, and in the wilderness, where keeping house was geared toward survival, women also relied on each other to keep that part of their identity. Women gave each other materials necessary for housekeeping and domestic duties, were present for the birth of a friend's child, or helped when a friend or friend's family member was ill. In a letter written in November of 1826, Anna Briggs Bentley, an Ohio woman, wrote of her close-knit female networks and how they provided support:

Levi's Ann gave me 2 hens and a rooster and Sarah Holland a pair of fowls to begin housekeeping with in the forrest. Poor Sarah has been ill for 3 weeks with erysipelas in her leg. She is able to sit up a little now. I spent yesterday there. She is such a dear, kind friend, so much dignity, such winning, affectionate manners. And she don't 'my dear' a body all to pieces neither. I think her daughters most amiable, interesting girls, and I love them dearly. Susan is spinning $3 \mathrm{lb}$ of stockings for me. ${ }^{107}$

\footnotetext{
${ }^{106}$ Mary Neth, Preserving the Family Farm: Women, Community, and the Foundations of Agribusiness in the Midwest, 1900-1940 (Johns Hopkins University Press: 1995), 2.

${ }^{107}$ Anna Briggs Bentley, Letter to Isaac Briggs, November 10, 1826. In Emily Foster, ed. American Grit: A Woman's Letters from the Ohio Frontier (The University Press of Kentucky, 2002), 51.
} 
Bentley's image of a female network in a frontier community was one of mutual support and affection. It could emulate familial ties, which they had left behind, and help remedy the immense homesickness they felt in their new homes.

Although women helped each other preserve republican, homespun virtues on the frontier, they did not completely disregard eastern fashion. Women associated civilization strongly with fashion, as it distinguished them as respectable white women contributing to the republic, what nineteenth-century America deemed as the feminine ideal. Through sophisticated fashion, white women distinguished them as "civilized," not "savage" like Native Americans nor "animalistic" like African Americans. As Glenda Riley observes, they thus "adopted such fashionable fads as hoopskirts, bustles, whalebone corsets, and heavily adorned dresses and bonnets." White women were afraid of falling into "barbarism" on the frontier, even though they were imagined as essential for preventing such a decline in the first place. While living a simpler and more hardworking life on the frontier, they did not come to live in "primitive" conditions, and certainly did not want to "become dowdy or outdated by eastern standards." ${ }^{108}$ Hence, while pioneer women were idealized in the East for their frontier simplicity, they inhabited this simpler ideal with eastern fashion standards in the back of their minds.

In this way, despite their homesickness, frontierswomen were not completely isolated from their sisters in the East - their ties to the eastern seaboard helped these women maintain "civilized" standards of living in the western wilderness. In the first half of the nineteenth century improved mail service began to create a cohesive national culture. By the $1840 \mathrm{~s}$, the country's telegraph network also expanded, strengthening the exchange of commercial and

\footnotetext{
${ }^{108}$ Glenda Riley, The Female Frontier: A Comparative View of Women on the Prairie and the Plains (University Press of Kansas, 1988), 109.
} 
intellectual information. ${ }^{109}$ Not only did pioneer women have more reliable and rapid access to friends and family in the East, but they could use these ties to keep up with trends and fashions associated with traditional Victorian womanhood. As Kera Storrs points out in her study of elite women in Bloomington, Illinois, in the mid-nineteenth century, the advent of the railroad allowed many local elites to obtain genteel home décor items from the East. Storrs writes that "These out of state purchases suggest that some elite families not only had sufficient funds to obtain high quality items, but believed that urban goods were superior to those in the Midwest." ${ }^{110}$ In other words, while frontierswomen were living in the idealized West, they were not fully isolated from their eastern connections — or urban capitalism.

The ever-popular fashion magazine market helped westering women keep up with the latest trends. Despite conceptions of the frontier as isolated and "backwards," frontierswomen eagerly read magazines like Godey's when they could not see the latest fashions for themselves in cities. Western women were such avid readers of Godey's fashions that by the second half of the nineteenth century, some clubs dedicated to the publication formed in Illinois, Ohio, Iowa, Texas, and as far as California. A woman in Ohio wrote to Godey's about the formation of her club, saying:

Here I come again with my club; no trouble to make it up. Your Book is so fascinating that it needs to be seen and read to gain admirers. The question is asked me, 'When are you going to send for the Lady's Book? Put down my name; can't do without it.'

\footnotetext{
${ }^{109}$ Rose, Voices of the Marketplace, 60.

${ }^{110}$ Kera Storrs, "Frontier Respectability to Gilded Age Splendor: Women and Consumerism in the Cultural Development of Bloomington, Illinois, 1839-1900." Order No. 1590170, Illinois State University, 2015, 142. http://libproxy.lib.ilstu.edu/login?url=https://www-proquest-com.libproxy.lib.ilstu.edu/dissertations-theses/frontierrespectability-gilded-age-splendor-women/docview/1692610113/se-2?accountid=11578.
} 
Similarly, an Illinois woman wrote: "I find your magazine is rapidly increasing in popularity in our Western country, for with a very little exertion I have succeeded in getting up this club." 111 Despite conceptions of the frontier as isolated and "backwards," frontierswomen eagerly consumed fashion magazines like Godey's and tried to emulate the Victorian fashions that were popular in their old eastern homes. Westering women's formation of clubs to keep up with fashion magazines also shows that not only were they consuming these fashions on the frontier, but they were forming and embracing their communities around the preservation of "civilized" fashion in any way possible.

Nevertheless, frontierswomen often found themselves having to adapt the world of fashion and all its complexities to their new roles. American sentimental culture dictated that a woman was beautiful without ostentatious fashion, and she could do her patriotic duty to cultivating republican virtue only when her innate moral qualities were not concealed by unnecessary frills. These women were aware that they had to set the example for virtuous economy, simplicity, and self-sufficiency, so they adhered to the simpler frontier fashion ideals out of expectation and practicality. Simpler fashions were a necessity for women on the frontier since they were often helping their husbands and families on farms. As Joanna Stratton points out, "In the dusty fields and open trails, there was little need or use for elegant fabrics or fashionable frills. Instead, clothing was kept simple, designed for practicality and economy.” 112 Hence, the frontier and family farm environment facilitated frontierswomen's economy, rendering them foils to eastern fashionable women -and in doing so, they epitomized ideals of the sincerity and simplicity that were so important to feminine ideals.

\footnotetext{
111 “Godey's Arm-Chair,” Godey's Lady's Book, 62-63 (February 1861): 471, http://www.godeysladysbook.com/February1861.htm.

112 Joanna Stratton, Pioneer Women: Voices From the Kansas Frontier (New York: Simon \& Schuster, Inc., 1981), 65 .
} 
They also spent a great deal of their time as domestic artisans making simple clothes for themselves and their families. Frontierswomen noted their work making clothing in their diaries, and they placed a high value on relying on their industry and economy to create virtuous fashions for themselves and their families, as well as their sisters in their communities. Simpler materials such as calico or flannel were used for many frontier fashions, as they were more practical for work on the family farm. For instance, an unidentified woman settling with her family and maintaining her household around Peoria, Illinois in the 1850s found it worth noting in her diary on February 22, 1858, that she "made Janie a flannel shirt in the evening." This woman also appears to have shared fashion materials with her fellow Peoria area women, as in March of the same year her diary notes that "Mrs. Nathaniel Chamberlain came and spent the afternoon gave her patterns for little things." ${ }^{113}$ Frontierswomen, then, were keeping up with the fashions of the East while being at the center of their own fashionable world of practical industry.

In bringing sentimental fashion and the civilized virtue it represented to the West, pioneer women were expanding American "civilization." The racist undertones of this endeavor can be seen in its impact on Native American women. Some Indigenous peoples adopted the fashion trends of frontierswomen, mostly as a means of survival as white western settlement disrupted and threatened their ways of life. Consequently, some Cherokee women adapted frontier fashion as a means to respectability. As Carolyn Ross Johnston points out, "Even the 'rougish' ones probably adopted new forms of dress. By 1830 most Cherokee women wore cotton or calico dresses in public, and men wore trousers. Outward symbols of acculturation did not necessarily signify that they majority of Cherokees had adopted Euro-American values. Many

113 “Pioneer Lady: Peoria's Secret Scribe,” Milner Library, https://transcription.library.illinoisstate.edu/collections/show/3. 
believed that tribal sovereignty depended on being viewed as civilized." Once the Cherokee were so affected by western settlement that class distinctions started emerging among them, many elite Cherokee women, according to Johnston, "cultivated domestic arts and outward symbols of gentility and respectability from their style of dress to the ways in which they furnished their houses." ${ }^{114}$ Thus, in their new western setting, many frontier women, in adapting fashion to their new roles and virtuous expectations, embodied an American ideal: they were adhering to republican virtues while spreading "civilization" to those they thought needed it.

Frontier life also shifted women's gender expectations, requiring a degree of strength and resilience that superseded that of their urban counterparts. It was the elevation of these qualities that distinguished frontier sentimentalism from the genteel sentimentalism of the east. What made the frontier different was that its main economy was one of survival, which brought women into traditionally "masculine" roles. Men were certainly still the patriarchs of their households, but women's work was now a large part of what made the difference between the family's frontier survival or doom. On the frontier farm, there were no "separate spheres," as Mary Neth argues, the family space was also an economic space on a frontier farm. ${ }^{115}$ In other words, the division between domestic spheres and the economic sphere which industrial capitalism had created was irrelevant on the frontier. The frontier environment instead hearkened back to the traditional republican ideal of the yeoman farm household.

In this context, frontierswomen were not simply dependents, but helpmates with value. Indeed, pioneer women, emigrated to the frontier with the images of frontier sentimentalism in

\footnotetext{
${ }^{114}$ Carolyn Ross Johnston, Cherokee Women in Crisis: Trail of Tears, Civil War, and Allotment, 1838-1907, (Tuscaloosa, University of Alabama Press, 2003), 49, 124.

${ }^{115}$ Mary Neth, Preserving the Family Farm: Women, Community, and the Foundations of Agribusiness in the Midwest, 1900-1940 (Johns Hopkins University Press: 1995), 17.
} 
which they were valued for their virtuous economy, self-sufficiency, industry, and heroic selfsacrifice for the benefit of their families. They then began to assign those values to their own work. For instance, Keturah Belknap wrote a record of her emigration to Oregon with her family in the 1840s. In her account, she found it important to note that she "can spin two skeins a day and in the evening will double twist it while George reads the history of the U.S. Then we read some in the Bible together and have prayer and go to bed feeling that the sleep of the laboring man is sweet." ${ }^{116}$ Here, Belknap not only proudly recorded her work spinning, but alluded to a yeoman republican ideal by noting that she and her husband can rest easy at night knowing the fruits of their labor were worth something.

In addition to their domestic duties, frontierswomen often assisted their husbands with farm work, if there were not enough hands. Once they were old enough, children helped as well. As John Faragher points out, "The work of children was important, but it was the work of farm wives that made the difference between success or failure of productive strategies...women produced an abundance of goods without which a family found it hard to survive." ${ }^{117}$ Women's work on farms still typically revolved around things that would produce household goods, such as poultry or gardens. ${ }^{118}$ In Faragher's study of Illinois settlement in the Sugar Creek area, a typical case of husband and wife cooperation looked like that of Mary and David McCoy. The couple "plowed their fields together—he pushing the plow, she driving the oxen, as their firstborn slept in a box strapped to the plow beam." ${ }^{119}$ Thus, while farm work was still gendered

\footnotetext{
${ }^{116}$ Keutrah Belknap, "Keutrah Belknap's Running Commentary," in Kenneth L. Holmes, ed. Covered Wagon Women: Diaries and Letters From the Western Trails, 1840-1849 (Bison Books: University of Nebraska Press, 1983), 205.

${ }^{117}$ Faragher, Sugar Creek, 101.

${ }_{118}$ Riley, The Female Frontier, 118.

${ }^{119}$ Faragher, Sugar Creek, 101.
} 
and women were still tasked with preserving the domestic sphere, they were now part of an environment of mutual value.

The cooperation and mutual dependence found in frontier marriages were illustrated with Rebecca Burlend, who, when her husband was injured in a farming accident, had to tend to the wheat. Burlend wrote in her memoir, "We had no means of hiring reapers, and my husband could not stir out. I was therefore obliged to begin myself; I took my eldest child into the field to assist me, and left the next in age to attend to their father and take care of the youngest, which was still unweaned." ${ }^{120}$ Burlend's writings provide an image of a family-based economy in which part of the self-sacrifice of sentimentalized frontier virtues was not merely emotional, but physical as well. Women such as Burlend had to step in for their families and do the work of their husbands in addition to their own when their spouses were injured or ill.

The notion of women as helpmates became part of frontier sentimentalism. Prior to the nineteenth century, marriages were typically arranged through strong parental guidance. Nineteenth-century Americans placed more emphasis on love as the basis for marriage through the rise of sentimental culture and its emphasis on feeling. Victorians cultivated romantic love through a period of courtship, through which young men and women could choose their spouses based on the expectation that marriage would provide emotional fulfillment. Romantic relationships also fostered mutual respect and feeling between spouses. No longer solely rooted in economics or parental expectations, the search for a spouse became the search for a companion, a person could be their "true self" around. In the East, these new ideas of romantic love were a driving cultural force. Additionally, romantic marriages afforded women more

${ }^{120}$ Burlend, A True Picture of Emigration, 91. 
power because, though their husbands still maintained their patriarchal authority, they were more willing to abdicate parts of that authority to please their wives in order to meet marital expectations of emotional fulfillment. ${ }^{121}$ The Victorian emphasis on feeling and bonds of affection through showing one's "true self" as preconditions to marriage carried such importance in sentimental America because genuine emotion and sincerity were so highly valued. This was important for women especially, for they could not preserve the republic through a virtuous household if they were not being the truest version of themselves.

When adapted to the frontier setting, the companionate ideal of marriage enhanced women's newfound roles and the agency within them. The crux of this marital shift is dependence. While in the sense of a linear historical progression, the companionate ideal represented progress for women, from property to life companion, there were tensions inherent in it. In the nineteenth century, love was conceptualized as, in Lystra's words, "a mysterious agency beyond human control," yet there was no ignoring the issue of economic female dependence. ${ }^{122}$ Economics still played a role in the selection of marriage partners and in the marital harmony, since hardly anyone wanted to move down the social ladder when marrying. Despite the emphasis placed on love, a man's economic stability was still often a precondition for being considered marriage material. Since women were meant to preserve the nation's moral fabric from their dominion in the domestic sphere, they were by no means expected to have economic autonomy. According to Lystra, husbands were expected "to provide a socially acceptable level of economic support for wives and children. Middle-class women expected (though did not always receive) the economic support which was an undisputed husbandly duty

\footnotetext{
${ }^{121}$ Lystra, Searching the Heart, 7-8, 157-191.
}

${ }^{122}$ Lystra, Searching the Heart, 206. 
in nineteenth-century American culture." ${ }^{123}$ Therefore, although love was supposed to be a sacred and mysterious force, the logic of separate spheres meant that women were economically dependent, which undercut the companionate ideal of marriage.

The cooperative family environment of the frontier saw husband and wife working together more in their western homes, without diminishing either gender. For instance, the Peoria area diarist, when recording the day's work, noted on May 4, 1858, that "Jerry and I looked over the barn for eggs." Since working with poultry was typically a woman's job on the frontier, it was Jerry, then, in this instance who crossed the gendered boundaries of work to help his wife. Perhaps most significantly, this Illinois woman appears to have been involved in the family's economic decisions along with her husband, including a large transaction in which they bought another home. On September 29, 1858 she wrote "Signed the deed to our Peoria home. Went up after ten o'clock to have it acknowledged." ${ }^{124}$ While this woman's situation is may be unique, it is not insignificant and provides a glimpse into what the cooperative environment of the frontier may have looked like.

Marriage, however, was not the only thing adapted to the frontier setting as Americans migrated. Gentility was democratized in eastern rural settings, but the same principles also applied to the frontier as well and became one of the virtues associated with the frontier. As Richard Bushman has pointed out, unlike the eighteenth century, nineteenth century gentility allowed middle and lower classes to adopt gentility, making it more accessible. Pioneer women still had the desire to cultivate respectable homes just like they kept up with the latest fashions of the East. They sought to bring their taste and refinement wherever they moved, as was their duty;

\footnotetext{
${ }^{123}$ Lystra, Searching the Heart, 218.

124 “Pioneer Lady: Peoria's Secret Scribe,” Milner Library, https://transcription.library.illinoisstate.edu/collections/show/3.
} 
even in rural settings, tasteful and grand houses did stand as evidence that "gentility and polite society had come to country towns." 125

In the nineteenth century, gentility, as Bushman terms it, can be viewed as a "rage to beautify," because the cultivation of beautiful spaces was associated with success and refinement, and buildings in rural settings were no exception. While those writing about gentility in the nineteenth century still advised virtuous simplicity for farm buildings and houses, such things still fell into the category of taste and refinement as "the plans for the large handsome barns, so admired today, were often taken from designs offered in agricultural periodicals." 126 Although Bushman was looking at rural settings in the east, the same principles applied to the western frontier. When "civilizing" the western "wilderness," the desire to assimilate eastern gentility to the new region showed itself in houses and even farm buildings - no corner of the "wilderness" would be spared from cultivating good taste.

In a time when the frontier epitomized American values of mobility, expansion, and selfsufficient independence, gentility moved with westward emigrants. While urban centers created anxieties about poverty and vice, or, on the other hand, ostentation, the frontier was imagined as a region free of urban corruptions, due to the self-sufficiency of hardworking pioneers. What place was better for gentility to become more accessible and democratic than the frontier? Frontierswomen could preserve civilization in the untamed west through spreading this refinement without fear of declining into aristocratic tendencies. Bushman notes that architectural authors "hoped that beautification would reach down through the social scale," and they "included small cottages among their designs with explicit notification that appropriate taste

\footnotetext{
125 Bushman, Refinement of America, 231, 241.

${ }^{126}$ Bushman, Refinement of America, 247.
} 
could rule there too." ${ }^{127}$ Good taste could be present in any dwelling, be it a fashionable urban home or a simple rural cabin.

The main marker respectable gentility was the appearance of the parlor in the home. Among the upper-middle-class rural population, the I house "appeared in virtually every section of the country as a residence for prosperous farmers," according to Bushman. I house plans "inserted a passage and a stair between the two first-floor rooms, providing an entrance hall and enabling the owners to treat one of the rooms off the hall as a parlor." ${ }^{128}$ The parlor was an essential room for cultivating genteel refinement, as it was where guests were entertained, and good taste was on display.

Although Bushman's focus was on genteel architecture in rural eastern settings, similar principles applied to the West. For women on the frontier, however, the significance of the parlor became something more - it was proof that they were succeeding in bringing "civilization" to the West. In his study of middle-class experience in the antebellum Midwest, Timothy Mahoney acknowledges the genteel impulses of frontier families. Mahoney uses an example of the Langworthy family, who was living in Iowa in the 1830s and 1840s. The Langworthy brothers built notable and magnificent country estates near each other, which emphasized the "material, ideological, political, and spiritual faith and vision of a stable, ordered, Victorian world resulting from the fusion of capitalism, republicanism, Christianity, and gentility." The estates of the Langworthy brothers appear to have had an influence on the community. As Mahoney points out, when Richard Bonson, a neighbor in the community, built a new house, he documented buying "another new carpet for the parlor chamber" and a "new black sofa." The Langworthy parlors,

\footnotetext{
${ }^{127}$ Bushman, Refinement of America, 249.
}

${ }^{128}$ Bushman, Refinement of America, 252. 
then, "set the tone for the rest of town society. Fully furnished with rugs and carpets and 'rose and cherry wood' 'carved furniture' purchased in New York and shipped via New Orleans, it was, in 1849, a model of High Victorian style." ${ }^{129}$ Thus, parlor culture not only was translated onto the frontier, but served as a "civilizing" influence, bringing stability to the new western setting.

Parlor culture facilitated an important genteel custom: visiting. This custom was even more vital out West due to the distance. Visitors could stay for an afternoon, or days on end, and even in the chaos of the frontier households needed to be ready to entertain at a moment's notice. For instance, the Peoria diarist appears to have had her own web of community connections who not only called on her, but vice versa. While it is unclear if she had a parlor in her two-story house, she did note in a June 30,1858 entry that she "cleaned the dining room today," that may have been a space for entertaining. The unnamed diarist notes most in her writings who calls upon her. On February 3, 1858, she noted "Gilbert Hathaway here." While she merely noted Hathaway's presence in this entry, in another entry she makes note of entertaining some callers, as on August 13, 1858, she wrote "Called to see Mrs. Swan. Just after I came home Mrs. Gusterf, Dr. \& Mrs. Chase came. Made ice cream for dinner. Had a heavy rain. They stayed till nearly night." The Peoria woman also called upon others, as in an entry from August 20,1859, she wrote "This morning Mother and I rode over to Mrs. Freeman's. After tea rode over to see Alice Chamberlain." ${ }^{130}$ Not only was this Illinois diarist entertaining in a dedicated space in her home and making dinner for friends who called upon her, but she was in her own refined social

\footnotetext{
${ }^{129}$ Timothy Mahoney, Provincial Lives: Middle-Class Experience in the Antebellum Middle West (New York: Cambridge University Press, 1999), 131-132.

130 "Pioneer Lady: Peoria's Secret Scribe," Milner Library, https://transcription.library.illinoisstate.edu/collections/show/3.
} 
network as well, one where even after her hard work on the frontier farm, she still made time to call upon friends for tea at their homes.

Unlike Rebecca Burlend, some frontierswomen's accounts do not denote financial hardships and leave traces of considerable wealth. While the Peoria woman's diary mainly recounts her daily occurrences and thoughts, she gave some indications as to her family's middle-class standing. Although her diary is later than Burlend's settlement in Illinois, the Peoria woman's narrative shows some differences. Not only did they purchase a second home in the upand-coming town Peoria in 1858, but the family's farmhouse outside of Peoria was two stories, another indicator of success out West. In a February 1858 entry, her diary states that "Jerry sat up stairs $[\mathrm{sic}]$ all evening with me." Other indicators of wealth in this Peoria-area family include that the diary-owner's mother "went up to the church to put down a carpet in our pew." Perhaps most significantly, the diary indicates that this family had hired help around their farm, as another entry from April 1858 states "Pasy here at work in the garden."131

In the more remote frontier setting, parlors were not always feasible for many families, but they still strived for refinement; codes of genteel etiquette even extended into log cabins. In an 1882 article for The Youth's Companion, one western traveler observed "Log Cabin Etiquette", in which "prominent among the virtues of the rough but not rude people of the Southwest, is the grace of hospitality. The author continues by stating that pioneers are always willing to entertain strangers, that "their log-cabin latch-string generally hangs out. He may pull it who will, and be assured of a welcome within." The article then cautions, however, that "he must pull it according to frontier etiquette, for in their rude region, as in more refined circles,

131 "Pioneer Lady: Peoria’s Secret Scribe,” Milner Library, https://transcription.library.illinoisstate.edu/collections/show/3. 
custom prescribes the form of introducing oneself to a family." Additionally, the article points out that if a westering traveler found themselves trapped for the night without an inn, they could ask for the token western brand of hospitality in a log cabin, but the rules of refined civilization were still at play; they had to approach cabins "as the pioneer code of politeness ordains." 132

This observer went on to illustrate how visitors to the West should act when approaching a frontier home with an example of traveling preacher. A visitor like the preacher can only "ride up to the fence that separates the cabin from the road." He should not dismount his horse and bang on the door, for "etiquette demands that he sit on his horse until asked to get off and come in." Once the mistress of the house (interestingly, the only note about this woman's appearance is that she is dressed in her "home spun and home-made linsey-woolsey") came out to greet the preacher and they exchanged pleasantries, he politely asked for lodging for the night in the lady's cabin, to which she replies "we never turn anybody away." Upon entering the cabin, he was "greeted with a hearty welcome, which was intensified as soon as she learned that her guest was a preacher. The husband repeats the greeting when he gets home, and all sit down to a supper of hot corn bread, potatoes, and coffee."133

The performance of etiquette when visiting homes of pioneers, however, did not end there. After their supper, "when it is bed-time, the preacher did not make the mistake of a verdant missionary. He politely said to the mistress of the house, 'Madam, I will retire, if you please.'” After his hostess showed him where he could sleep, the preacher had one more obligation before

\footnotetext{
132 “Log-Cabin Hospitality." The Youth's Companion (1827-1929), Jan 26, 1882, 30, http://libproxy.lib.ilstu.edu/login?url=https://www-proquest-com.libproxy.lib.ilstu.edu/magazines/log-cabinhospitality/docview/127053875/se-2?accountid=11578.

133 “Log-Cabin Hospitality.” The Youth's Companion (1827-1929), Jan 26, 1882, 30, http://libproxy.lib.ilstu.edu/login?url=https://www-proquest-com.libproxy.lib.ilstu.edu/magazines/log-cabinhospitality/docview/127053875/se-2?accountid=11578.
} 
retiring, as the husband brought out the family Bible and asked the preacher to lead devotion. After devotional exercises, the preacher retired to his designated bed in the one room cabin. The next morning, the preacher thanked his hosts by telling the couple "I' $m$ indebted to you for a night's entertainment." To which they replied, "Not at all, sir. Come to stay with us again, whenever you pass by this way." It was proper frontier etiquette for the preacher to offer his gratitude instead of a monetary payment to the couple, for "if he had offered payment, it would have been regarded as a reflection on their hospitality." 134 Thus, hospitality had become part of visiting in the frontier, but there was also a code of etiquette that adapted genteel performance to the West.

Frontier refinement was not just confined to hospitality, but to also daily activities such as mealtimes. Rebecca Burlend made note of some Midwest etiquette in her frontier account. Making sure to adapt the customs and manners of her new home, she notes that "It is not etiquette in Illinois to sit at the table after you have done eating; to remain after you have finished your meal implies that you have not had sufficient. This custom I subsequently found a very convenient one." ${ }^{135}$ Giving a glimpse into regional dining etiquette very fitting for the Midwest, even with her economically poor start in the Illinois frontier, people such as Burlend were making sure to practice the manners of the refined.

It appears as though pioneer etiquette persisted into the latter half of the nineteenth century, as seen in publications such as Kansas Home Cook Book published in 1886. One piece of table manners the cookbook disseminated hearkened back to Burlend's note on refined

\footnotetext{
134 “Log-Cabin Hospitality.” The Youth's Companion (1827-1929), Jan 26, 1882, 30, http://libproxy.lib.ilstu.edu/login?url=https://www-proquest-com.libproxy.lib.ilstu.edu/magazines/log-cabinhospitality/docview/127053875/se-2?accountid=11578.

${ }^{135}$ Burlend, A True Picture of Emigration, 47.
} 
behavior: "Avoid all appearance of haste at the table, but as soon as you are helped, begin to eat. The custom of waiting is obsolete." In another piece of etiquette advice, Kansas Home stated that "Fruit is eaten with a silver knife and fork, after which you dip your fingers in the fingerbowl. ${ }^{136}$ Hence, even into the late the nineteenth century, the frontier was not as rude and unrefined as some perceived; it was a region where refinement spread in most circles, where there was a frontier code of etiquette that even those who had disadvantaged starts followed.

While the frontier was imagined in a sentimental world as inherently virtuous and selfsufficient because of its perceived distance from capitalism, the reality of the region did not always match this ideal. Burlend is quite honest in her account of western migration that she and her family initially strongly regretted their choice to move. Noting her initial thoughts, Burlend states that "We indeed had some good land, but it was nearly all uncultivated, and we had nothing to sell except our cattle, which we wanted. The only ground of hope we had was in our industry and perseverance." ${ }^{137}$ Burlend's narrative shows she internalized frontier sentimentalism in her new Midwestern home. She sees industry and determination as frontier virtues; something she possessed even when she had few material comforts. The narrative of Rebecca Burlend's emigration to Illinois also has traces of the adaptation of the democratization of gentility into frontier sentimentalism. While she accounts her initial regrets in her move to the Midwest, by the end of her account the Burlend family's industry and perseverance led to prosperity.

\footnotetext{
${ }^{136}$ Cushing, Mrs. C.H. and Gray, Mrs. B., The Kansas Home Cook Book 1886 Reprint (Arno Press: New York, 1973). In Swell, Barbara. Log Cabin Cooking: Pioneer Recipes and Food Lore (Native Ground Music Inc., 1996), 22.

${ }^{137}$ Burlend, A True Picture of Emigration, 71-72.
} 
Burlend credits the success of her family to their virtuous qualities, including not only hard work and determination, but self-sufficiency. She writes, "one thing I would notice as a cause of our ultimate prosperity, is, that having a family, we have been greatly assisted in the culture of our land, without having so much to hire as we should otherwise have been obliged." ${ }^{138}$ Making their initial landing in America in Louisiana, the Burlends had to ride through the South to get to Illinois, where they saw slavery up close. Burlend specifically expressed her distaste for slavery in her account. In admiring the beautiful scenery of the American countryside she notes that "There was, nevertheless, one drawback: these beautiful plantations were cultivated by slaves, many of whom we saw as we passed along." ${ }^{139}$ Thus, in establishing her distaste for American slavery, Burlend's attribution of her family to achieving prosperity takes on more depth; for Burlend, they did not have the luxury of hiring help but they were inherently more virtuous because they built themselves up without slaves.

Burlend wraps up her account of emigration with an exercise in perspective, in which she implies that her family's struggles built character and were therefore necessary for the enjoyment of their present prosperity, as if their industry made their success more enjoyable. Burlend notes that "man's career in prospective is always brilliant; and it is providentially ordered that it should be so. Could we have forseen our destiny, the prospect would have thrown us into despair. It would have robbed us of much of our present enjoyment, and unfitted our minds for the difficulties with which we had to struggle." ${ }^{140}$ Hence, even though Burlend came from England, she quickly took up the patriotic ideal of the virtuous republican frontierswomen. Her pamphlet on emigration was not only her honest picture of the hardships and potential turmoil of western

\footnotetext{
${ }^{138}$ Burlend, A True Picture of Emigration, 152.

${ }^{139}$ Burlend, A True Picture of Emigration, 36.

${ }^{140}$ Burlend, A True Picture of Emigration, 75.
} 
migration, but also an encouragement to any considering the move; that genteel, respectable living was attainable through virtuous qualities inherent in frontier sentimentalism.

Many families ventured West with little money and few possessions, only carrying the American Dream on their shoulders of starting a successful family farming enterprise — as honest as work could get amid the changes of the nineteenth century. For families such as the Burlends, emigrating to America and then to the western frontier itself, money was tight. Burlend notes that in the 1830s when they emigrated, Illinois was thinly populated, and she warns that it was not the place for shopkeepers at the time. Noting that there were store keepers in various places who supplied settlers with basic necessities in exchange for farm produce, Burlend points out that "As these store keepers exercise a sort of monopoly over a certain district, their profits are great, and they often become wealthy." 141 Thus, even in the virtuous American West, the enterprising spirit that began to characterize American identity and draw settlers out to the region produced some class stratification.

Because of this arrangement in Illinois settlement, the Burlend family ran into some financial woes in their new home. The family was at risk of losing their home at one point, owing \$30 to a Mr. Vanderoozen for a cattle loan. On the brink of despair, the Burlend family was saved by a neighbor exemplifying the community spirit of the frontier. Mrs. Burlend states that when her husband returned from answering a knock at the door one morning, "he told me that Mr. B. had brought us the money, and gone away saying he could not rest any longer without lending it." ${ }^{142}$ Hence, while class stratification did exist out west, those who settled there

\footnotetext{
${ }^{141}$ Burlend, A True Picture of Emigration, 67.
}

${ }^{142}$ Burlend, A True Picture of Emigration, 119. 
tended to view community spirit of the frontier environment tended to be one of tight-knit cooperation rather than the cold anonymity of eastern cities.

If some families were living rather comfortably out West, were they living too similarly to their eastern counterparts, contradicting this frontier ideal? Yet, even for families like the Peoria woman's who were well-off enough to have some hired help around their farm, the frontierswomen of means still viewed their work and role as that of duty to "civilization" under the values of frontier sentimentalism. As Neth notes, while women in the urban settings of the East often had the label "leisurely" applied to their roles, for pioneer women, "leisurely standards of domesticity were not the model, even for farm women whose work most closely resembled urban, middle-class norms." ${ }^{143}$ The inherent cultural strength of frontier sentimentalism and the values applied to it was something frontierswomen took seriously and adhered to in the name of patriotic virtue.

Even though she had some hired assistance, the Peoria woman's diary still reveals her work on the farm. In one of the diary's first entries in December 1857, the Peoria woman wrote “Up early. Did Budgel's work and peared apples before breakfast.” As a dutiful mother, she also records her daughter Alice — who was quite young, only five years old at the start of the diarydoing some tasks around the farm; on the same day she wrote: "After dinner Alice took her wheel barrow $[s i c]$ and wheeled over shavings from the barn. Alice got a letter from her Aunt Amelia." Values of hard work were instilled in her from a young age. Even with a measure of hired help, Alice's mother kept the farm going when her husband Jerry was away. On March 31, 1858, she recorded: "Jerry gone into Peoria. The girls cleaning Lindals and their rooms. John

\footnotetext{
${ }^{143}$ Mary Neth, Preserving the Family Farm, 28.
} 
Colgan came for shrubbery. After dinner Dickinson's nephew and Charlie Rettelle called here. Mother and I sodded a mound in the front yard." ${ }^{144}$ This diarist, valuing her farm work, and that of her daughters, by recording it in her diary. While it is unclear if she read Child's domestic treatise, her record indicates that she was in accord with her advice of practicing virtuous industry and instilling such useful values the children. ${ }^{145}$

Such personal means of record keeping became important markers of frontier women's civilization that tied them to the East. As Gayle R. Davis emphasizes, diaries were mediators between "the author's self-perception as a Victorian lady and her feared loss of that identity in the wild. A propensity for journal writing was a well-accepted sign of gentility in the nineteenth century. Journals were seen as a means of improving one's expressive skills and sense of discipline." ${ }^{146}$ Diaries, however, were not just signs of gentility; they were also the means through which they adapted frontier sentimental values to their identities. Through their journals, western women could reconcile their new roles with the old; they could meet traditional Victorian ideals gentility through their self-expression, while, at the same time, recording their adherence to virtuous, hardworking frontier ideals.

Pioneer women's frontier narratives were packed with emotion. Fearing the loss of womanhood, women found the longer they spent on the frontier, the more they found comfort in frontier values, while still maintaining acceptable parts of traditional sentimental womanhood. Women like Sarah Bayliss Royce - a woman migrating West with her family in the 1840s, eventually reaching California — shared these fears, but eventually women like Royce create in

\footnotetext{
144 “Pioneer Lady: Peoria’s Secret Scribe,” Milner Library, https://transcription.library.illinoisstate.edu/collections/show/3

145 See Chapter One that addresses Child's American Frugal Housewife.

${ }^{146}$ Gayle R. Davis, “Women's Frontier Diaries: Writing for Good Reason,” Women's Studies, 14 (1): 7. doi:10.1080/00497878.1987.9978682.
} 
their narratives the image, as Deborah Lawrence points out, "of a hardy woman of great courage and fortitude. Her writing reveals her daily routine on the frontier and the ways in which she asserts herself. But her daily tasks do not divert her from her relationship with God."147

Women such as Royce found that the frontier allowed them to still be women in the traditional, sentimental sense that valued their moral superiority through their relationships with God and the rhetorical sanctity of the domestic spheres. Like many other women, however, Royce found emotional standards of sentimentalism shifting in their new environments. Women could now express strength and courage on the frontier, for example. Royce wrote during an initial night of homesickness that "in the morning there was a mildly exultant feeling which comes from having kept silent through a cowardly fit, and finding the fit gone off." ${ }^{148}$ This expression of euphoria upon surviving a "cowardly fit" brought her a new self-definition as a capable and courageous frontier woman.

Diaries were not the only means of women recording their identity shift into the frontier idea. Since they were often in communication via letter with their sisters in the East, their letters also conveyed their journey into idealized frontierswomen. Some women, like Louise Smith Clappe, another California emigrant among the gold rush fever of the 1850s, framed their journey West as one of personal transformation. In letters to her sister Molly, who was still in Massachusetts, she juxtaposes traditional and frontier sentimentalism by comparing images of her past and present self. In this series of letters, she wrote to her sister between 1851 and 1852, Clappe published these letters in 1854 in San Francisco's literary monthly, Pioneer under the

\footnotetext{
${ }^{147}$ Deborah Lawrence, Writing the Trail: Five Women's Frontier Narratives (Iowa City: University of Iowa Press, 2006), 38.

${ }^{148}$ Lawrence, Writing the Trail, 39.
} 
pseudonym "Dame Shirley," providing a primary representation of a fully sentimentalized frontierswoman. In a telling letter, Clappe wrote:

Here, at least, I have been contented. The 'thistle seed,' as you called me, sent abroad its roots right lovingly into this barren soil, and gained an unwonted strength in what seemed to you such favorable surroundings. You would hardly recognize the feeble half-dying invalid, who drooped languidly out of sight, as night shut down between your straining gaze and the good ship Manilla, as she wafted her far away from her Atlantic home, in the person of your now perfectly healthy sister. ${ }^{149}$

Clappe used a transformation arc of sorts to describe her present self to her now distant sister. She found strength by casting her "thistle seed" roots lovingly into the "barren soil." Casting her roots now into nature's bounty in the West, she found her true identity as a strong woman who, at the same time, is bringing civilization to the barren West. Perhaps most interesting is how she defined her identity in her old home and her new: in the everindustrializing East, she was a "feeble half-dying invalid," yet out West in the more favorable and virtuous surroundings she became "perfectly healthy," and therefore unrecognizable to her sister. The frontier transformed women like Clappe into capable, more healthy women who found strength in the western soil, countering the implied cultural notion that their female counterparts in the East were fragile and too domesticated.

Frontier sentimentalism was a guide to identity for westering women in the nineteenth century, and in publishing their narratives and letters these women were contributing to frontier sentimentalism. In reconciling their new lives with their comfortable Victorian past, frontierswomen took frontier sentimentalism seriously and adopted its values, knowing the weight of their culturally prescribed roles. Frontier sentimentalism ideologically preserved the

\footnotetext{
${ }^{149}$ Lawrence, Writing the Trail, 81.
} 
virtuous republican identity founded with the nation while simultaneously spreading the enterprising capitalistic spirit of conquest that many found problematic in the East. Frontier sentimentalism, then, became a new mirror through which nineteenth-century Americans could view themselves; for as long as these virtuous, heroic, and capable women were doing their part in preserving western frontier ideals, the foundation of the nation was safe. It is precisely because frontier sentimentalism was taken so seriously by pioneer women and projected so heavily onto them, it remained a cultural standard throughout the century, and was cemented into the fabric of American identity for future generations. 


\section{CHAPTER V: CONCLUSION: LASTING LEGACIES: LAURA INGALLS WILDER AND FRONTIER NOSTALGIA}

By the late nineteenth century, frontier sentimentalism was thoroughly embedded in American cultural identity. The women who had been tasked with preserving the nation's virtue had produced a literary republican ideal that later became reality for frontierswomen migrating West. By the 1890s, the frontier had "closed," but only in a geographical sense. As Richard White points out, it had become a central component of American folklore: the frontier was the means by which "a diverse people of European origins had remade themselves into Americans." Additionally, the frontier meant a distinct American form of progress, rooted in "growing democracy, greater equality, more opportunity." ${ }^{150}$ Although the West was settled by the turn of the century, it did not fade away. Instead, it persisted in the realm of nostalgia. The frontier had come to characterize a distinct American exceptionalism. As time progressed away from frontier settlement and into an increasingly modern age, people were nostalgic for the simpler virtues of the age of agrarian republicanism.

The most prominent example of frontier sentimentalism in the twentieth century can be found in Laura Ingalls Wilder's Little House books. In 1911, Wilder began writing for the Missouri Ruralist, through which, like her counterparts of the nineteenth century, she disseminated homespun advice to other women. "I must say if there are any country women who are wasting their time envying their sisters in the city—don't do it," she wrote in one issue. "Such an attitude is out of date. Wake up to your opportunities...the real cultured, social and

\footnotetext{
${ }^{150}$ Richard White, "Frederick Jackson Turner and Buffalo Bill," in Richard White and Patricia Nelson Limerick, The Frontier in American Culture (Los Angeles: University of California Press, 1994), 13.
} 
intellectual life will be out in the country." ${ }^{151}$ With this, Wilder continued to disseminate the idea that the real cultural center and the essence of the nation was in the frontier. In addition, Wilder associated the frontier with the "land of opportunity" in America, not just for men, but for women as well.

Wilder was born in 1867 in rural Wisconsin and certainly was raised amidst the established currents of frontier sentimentalism. Throughout her literary career, she painted her childhood as a frontier fairytale, most famously in the Little House series, which she began writing when she was in her fifties. Wilder let readers into her comfortable frontier home and her hardworking and loving family, allowing them to feel as if they, too, were experiencing this quintessential American idyllic frontier life. Her first book of the series, Little House in the Big Woods, was published in 1932. It begins quite literally like a fairytale: "Once upon a time, sixty years ago, a little girl lived in the Big Woods of Wisconsin, in a little gray house made of logs." ${ }^{152}$ This first book was incredibly successful and became a series because Wilder received an abundance of requests for more. ${ }^{153}$

Perhaps Wilder's frontier nostalgia was so marketable because Little House in the Big Woods was released right as the Great Depression was ravaging America. The pastoral images she evoked preserved hope that the nation still had its characteristic identity. The self-sufficient and resilient image of the frontier could provide solace in the face of so much upheaval and suffering. As Deborah Lindsay Williams argues, Wilder's work emerged as an invaluable resource during a time of turmoil that could "help the nation return to an idealized pioneer

\footnotetext{
${ }^{151}$ Quoted in Sallie Ketcham, Laura Ingalls Wilder: American Writer on the Prairie (New York: Routledge, 2015), 95.

152 Ketcham, Laura Ingalls Wilder, 1.

${ }^{153}$ Laura Ingalls Wilder, A Little House Traveler: Writings From Laura Ingalls Wilder's Journeys Across America (New York: Collins, 2006), 5-11.
} 
sensibility of frugality and self-sufficiency." ${ }^{154}$ The Great Depression and the Dust Bowl had destroyed so many American family farms, and, as seen as in the famous photographs from the Work Progress Administration and other forms of Great Depression-era cultural production, the farmer was once again at the heart of American culture, and came to signify the suffering of all Americans.

Wilder's work follows and promotes tropes of frontier sentimentalism established nearly a century earlier. From the perspective of her childhood, Wilder constructs an idealized domestic frontier space. The spaces are gendered, of course: she, Ma, and her sisters Mary and Carrie primarily inhabit the domestic space where they do their chores; yet their work is essential to the family's survival. $\mathrm{Pa}$ is the main provider who goes out into the wild and mysterious woods to hunt food for the family, coming back to the "civilized" hearth of the women in his life. The family hearth, traditionally sentimentalized and idealized in frontier sentimentalism as the cradle of "civilization," is similarly depicted in Wilder's novelization of her childhood. In Little House in the Big Woods, as Laura sits with her family before the warm hearth, "she thought to herself, 'This is now.' She was glad that the cosy [sic] house, and Pa and Ma and the firelight and the music, were now. They could not be forgotten, because now is now. It can never be a long time ago." ${ }^{155}$ Here, Wilder not only idealizes the family unit in a sentimental sense, but it gives a glimpse into her motivation for writing. She does not want these moments in time to slip away. She represents her frontier childhood as a key component of her identity and wants to keep it alive and share it.

\footnotetext{
${ }^{154}$ Deborah Lindsay Williams, Review of Constructing the Little House: Gender, Culture, and Laura Ingalls Wilder, Studies in American Fiction 27, no. 2 (1999): 251-253. doi:10.1353/saf.1999.0009.

${ }^{155}$ Laura Ingalls Wilder, Little House in the Big Woods (New York: Scholastic Inc. Harper Collins, [1932] 1959), 238. In Pat Louw, "Contested Spaces in Laura Ingalls Wilder's Little House in the Big Woods and Little House on the Prairie," Mousaion 29, no. 3 (2011): 166-178.
} 
In keeping with sentimental qualities, the family unit is essential to Wilder's characterization of her childhood. In particular, she idealizes the self-contained, individualistic family. As literary scholar Anita Clair Fellman has pointed out, readers of Wilder's popular series see "both how a self-sufficient family, responsible for its own successes, manages to survive many challenging circumstances without the aid of the government and how that selfsufficiency is somehow tied to the admirable values of individual responsibility taught by the tight, cohesive, and loving family." ${ }^{156}$ Fellman argues that Wilders' books, in this way, have had some political influence, especially considering their enduring pervasiveness in classrooms, libraries, and living rooms across the country.

The sentiments Wilder expresses echo those of Lydia Marie Child and Catherine Sedgwick illustrated in the first two chapters of this study. The disdain for falling into poverty is remedied by the self-sufficient family unit comprised of responsible citizens. Even in Wilder's twentieth-century writings, the emphasis is on the family unit, the basis of "civilization" and a distinct American ethos of freedom. Women like Wilder, Child, and Sedgwick were part of an enduring movement, one that shaped American exceptionalism that characterizes our national mythos today. The "land of opportunity" that Wilder encouraged women to find in the country solidified the American identity that her foremothers were tasked with forming; yet the image these women created of a virtuous republic comprised of self-sufficient individuals was also one that ignored deep-rooted problems.

\footnotetext{
${ }^{156}$ Anita Clair Fellman, Little House Long Shadow: Laura Ingalls Wilder's Impact on American Culture (Columbia: University of Missouri Press, 2008), 251. In Amy Mattson Lauters, Review of Laura Ingalls Wilder and Rose Wilder Lane: Authorship, Place, Time and Culture, and: Little House Long Shadow: Laura Ingalls Wilder's Impact on American Culture, American Studies 50, no. 1 (2009): 213-215. doi:10.1353/ams.2011.0039.
} 
Frontier sentimentalism emerged in the nineteenth century to remedy the intense social changes that were causing turmoil among Americans: market capitalism and class disparities that emerged from it, urbanization, industrialization, and by mid-century, slavery. Historian Greg Grandin has postulated that the kind of America that Frederick Jackson Turner envisioned was an idealistic escape from the nation's contemporaneous problems, creating a legacy persisting into the present. He writes that Turner's vision bet that "the country's progress, moving forward on the frontier and into the world, would reduce racism to a remnant and leave it behind as residue. It would dilute other social problems as well, including poverty, inequality, and extremism, teaching diverse people how to live together in peace." ${ }^{157}$ Western expansion, then, only served as an escape from the issues that made many Americans uncomfortable in the nineteenth century. The frontier in theory was supposed to serve as the great American equalizer, cementing the image of a land of opportunity where everyone could make it if they adhered to the self-sufficient ethos. They idyllic frontier, however, did not actually work to mitigate the structural issues Grandin addresses. The American myth, then, has fed into an idealistic vision that has long been employed to dodge problems rather than face them head on.

Grandin's analysis of the American frontier myth, however, is rather Turner-focused. While Turner was influential in cementing that myth, he was co-opting images that had already been well-established-images that women were responsible for creating. The creation of this very American myth was dependent upon women, for as the men pushed forward geographically, women advanced a new cultural ethos. Women used sentimentalism to associate simple republican virtues of self-sufficiency, moral fortitude, good economy, and resilience with an idealized rural landscape. Projecting republican virtues onto a supposedly empty western

\footnotetext{
${ }^{157}$ Grandin, The End of The Myth, 2.
} 
landscape proved a fruitful solution to the urban chaos troubling Americans at the time. Women like Child and Sedgwick preached these virtues in fiction and advice literature; without them, the character of a once virtuous republic could fade into memory. When women migrated to the frontier with their families, they felt it their duty to preserve these virtues - and the "civilized" foundation of the nation. These rural virtues, then, came to be associated not only with frontierswomen, but the region—and American identity—itself.

In the twenty-first century especially, the image of the frontier-oriented American myth is, generally, less associated with Turner, as most of the general population outside of academic circles do not know who he is or have not read his work. Yet, most Americans know of Wilder (who would have been an adult when Turner presented his "Frontier Thesis" in 1893) and the sentimental vision she paints of her frontier childhood. In a way, Wilder's work is the enduring twentieth-century culmination of the identity-crafting literary tradition of her foremothers; her stories have been passed down for generations. New forms of media have also made this image more accessible to Americans, as even in 2021 reruns of the television adaptation of Little House on the Prairie are still aired. The image Wilder crafted of her idyllic frontier childhood with Ma, $\mathrm{Pa}$, and the rustic, yet cozy home they shared evokes nostalgia for a time we are generations removed from; yet it still resonates with many because frontier sentimentalism has become such an essential and enduring part of what it means to be American.

Is Wilder's brand of frontier nostalgia so appealing because as twenty-first century Americans are, we, too, afraid of change? The idealization of the frontier and its association with American identity (and exceptionalism) was born of the desire to escape a rapidly urbanizing America that was becoming too capitalistic for comfort. Wilder, too, wrote her childhood as a frontier fairytale with the desire to preserve that supposedly simpler time, worried it would fade 
and be forgotten forever. Yet, one cannot help but consider how this so-called "simpler time" was anything but "simple." Perhaps it is the historians' healthy skepticism of nostalgia, but Grandin's work does bring up some key concerns in learning from the past. Does the nostalgia for the "simpler time" associated with the origins of our national myth prevent progress when the nation has been avoiding its deep-rooted problems since the nineteenth century?

Grandin's work culminates in the assertion that in our present-day moment, the "border wall" is the new "frontier." Ideas of borders and boundaries are now as extensive as the frontier once was. As Grandin writes, the border wall "became a symbol of a nation that used to believe that it had escaped history, or at least strode atop history, but now finds itself trapped by history, and of a people who used to think they were captains of the future, but are now prisoners of the past." ${ }^{158}$ With this, borders have closed in what was once deemed a bountiful frontier ready for expansion.

Geographically, the border may have replaced the frontier, yet the legacy of the frontier remains very much part of American mythology. As contemporary struggles with social inequalities and racism highlight long-term problems, we continue grappling with the powerful and enduring legacy our foremothers were tasked with crafting. In some ways, we find ourselves in a similar position to nineteenth-century Americans, where we can ask ourselves: are we the nation we say we are? Will we remain trapped by our national myth? Will this nostalgia hinder progress, or will the myth become a rhetorical frontier, expanded and more accessible to everyone? Perhaps that is one for historians of the culture wars to grapple with. Time will tell if we are to pick up where these women left off in defining our own version of America, yet there

\footnotetext{
${ }^{158}$ Grandin, The End of the Myth, 9.
} 
is no denying their success in creating a powerful and distinct American ideal; for the legacies of Wilder and her foremothers are not far behind us. 


\section{REFERENCES}

Primary Sources

Beecher, Catherine. A Treatise on Domestic Economy for the Use of Young Ladies at Home and at School, $3^{\text {rd }}$ rev. ed. New York: Harper and Brothers, 1858. In Ruth Barnes Moynihan, Cynthia Russett, and Laurie Crumpacker, eds., Second to None: A Documentary History of American Women, Volume I: From the 16 ${ }^{\text {th }}$ Century to 1865. Lincoln: University of Nebraska Press, 1993.

Burlend, Rebecca, and Edward Burlend. A True Picture of Emigration. Edited by Milo Milton Quaife. Lincoln, NB: Bison Book, 1987.

Child, Lydia Maria. Hobomok: A Tale of Early Times. 1824. Karcher, Carolyn L., ed. Hobomok and Other Writings on Indians. Rutgers University Press: New Jersey, 1986.

Child, Lydia Maria. The American Frugal Housewife. Boston: Carter, Hendee, and Co., 1833.

Cushing, Mrs. C.H. and Gray, Mrs. B., The Kansas Home Cook Book (1886. Reprint, New York: Arno Press, 1973). In Swell, Barbara. Log Cabin Cooking: Pioneer Recipes and Food Lore, (Native Ground Music Inc., 1996), 22.

“Domestic Duties,” Godey's Lady’s Book, 12 (January 1836): 6, https://hdl.handle.net/2027/njp.32101064242066? urlappend=\%3Bseq=24.

"Editors' Table.: A Young Lady's Ideas of Western Life. Reply to the Wish of a Young Lady. Places of Education for Young Women." Godey's Lady's Book and Magazine, 5 (1857):465, http://libproxy.lib.ilstu.edu/login?url=https://www-proquestcom.libproxy.lib.ilstu.edu/docview/126089174? accountid=11578.

Foster, Emily, ed. American Grit: A Woman's Letters from the Ohio Frontier. The University Press of Kentucky, 2002.

Foster, Emily, ed. The Ohio Frontier: An Anthology of Early Writings. The University Press of Kentucky, 1996.

"Frontier Women." Harper's Bazaar (1867-1912), Aug 11, 1877, 498, http://libproxy.lib.ilstu.edu/login?url=https://search.proquest.com/docview/125678442?accountid $=11578$.

Frost, John. Daring and Heroic Deeds of American Women, Comprising Thrilling Examples of Courage, Fortitude, Devotedness, and Self-Sacrifice, Among the Pioneer Mothers of the Western Country. Philadelphia: G.G. Evans, 1860. https://archive.org/details/daringandheroic00frosgoog/page/n12/mode/2up.

“Godey’s Arm-Chair,” Godey’s Lady’s Book, 62-63 (February 1861): 471, http:/www.godeysladysbook.com/February1861.htm. 
Hale, Sarah Josepha. Sketches of American Character. Philadelphia: Perkins \& Purves, 1843, https://archive.org/details/sketchesofameric00hale/page/n3/mode/2up.

"Heroic Women of America. -No. 1. The Lady and the Arrows." Godey's Lady's Book, 29 (July to December 1844): 229-230. https://archive.org/details/Godey29/page/n251/mode/2up?q=pioneer.

Holmes, Kenneth L., ed. Covered Wagon Women: Diaries and Letters From the Western Trails, 18401849. Bison Books: University of Nebraska Press, 1983.

L.A. Godey\& Co., “The Latest London Fashions-Caps and Bonnets," Godey's Lady's Book, 3 (July 1831): 8. https://hdl.handle.net/2027/njp.32101064241894?urlappend=\%3Bseq=18.

L.A. Godey\& Co., "Philadelphia Fashions," Godey's Lady's Book and Magazine, 7 (July 1833): https://hdl.handle.net/2027/njp.32101064241860?urlappend=\%3Bseq=10.

“Log-Cabin Hospitality.” The Youth's Companion (1827-1929), Jan 26, 1882, 30, http://libproxy.lib.ilstu.edu/login?url=https://www-proquestcom.libproxy.lib.ilstu.edu/magazines/log-cabin-hospitality/docview/127053875/se2? accountid $=11578$.

London Magazine, “Garden Operations for Ladies,” Godey’s Lady’s Book, 3 (July 1831): 10, https://hdl.handle.net/2027/njp.32101064241894? urlappend $=\% 3 \mathrm{Bseq}=20$.

"[Lydia] Maria [Child] ALS to Louisa [Gilman Loring], May 30, 1836," in Lydia Maria Child Papers, Clements Library, University of Michigan, http://quod.lib.umich.edu/c/child/child.0001.003/1.

“Mrs. D.L. Child [Lydia Maria Child] ALS to Unidentified, April 18, 1831," in Lydia Maria Child Papers, Clements Library, University of Michigan, http://quod.lib.umich.edu/c/child/child.0001.001/1.

"Pioneer Lady: Peoria’s Secret Scribe,” Milner Library, https://ranscription.library.illinoisstate.edu/collections/show/3.

Sedgwick, Catharine Maria. The Poor Rich Man, and the Rich Poor Man, New York: Harper \& Brothers, Cliff-Street, 1836.

“The Queens of Europe,” Godey's Lady’s Book, 12 (January 1836): 3, https://babel.hathitrust.org/cgi/pt?id=njp.32101064242066\&view=1up\&seq=19.

“True Beauty,” Godey’s Lady’s Book, 2 (January 1831): 199, https://hdl.handle.net/2027/njp.32101064241902? urlappend=\%3Bseq=211.

“The Snow Feather; A Tale," Godey's Lady's Book, 7 (July, 1833): 1-11, https://hdl.handle.net/2027/njp.32101064241860?urlappend=\%3Bseq $=13$. 
Turner, Frederick Jackson. "The Frontier in American History.” Rev. ed. Tucson: University of Arizona Press, 1994. Print, In Danver, Steven L. "The Significance of the Frontier in American History." Defining Documents in American History: The Emergence of Modern America (18741917). Hackensack: Salem, 2014. Accessed August 25, 2020.

Williston, Clara P. "The Pioneer's Daughter" Godey's Lady's Book and Magazine, 7 (1857):16-20, http://libproxy.lib.ilstu.edu/login?url=https://www-proquestcom.libproxy.lib.ilstu.edu/docview/126096083?accountid=11578.

\section{Secondary Sources}

Adams, Jane. The Transformation of Rural Life: Southern Illinois, 1890-1990. University of North Carolina Press, 1994.

Anderson, Greta. More Than Petticoats: Remarkable Ohio Women. Guilford, CT: The Globe Pequot Press, 2005.

Blackwell, Marilyn S. and Oertel, Kristen T., Frontier Feminist: Clarina Howard Nichols and the Politics of Motherhood. University Press of Kansas, 2010.

Burstein, Andrew. Sentimental Democracy: The Evolution of America's Romantic Self-Image. New York: Hill and Wang, 1999.

Bushman, Richard L. The Refinement of America: Persons, Houses, Cities. New York: Vintage Books, 1993.

Butler, Judith. Gender Trouble: Feminism and the Subversion of Identity. New York: Routledge, 1990.

Cashin, Joan E.A Family Venture: Men and Women on the Southern Frontier. Baltimore, MD: Oxford University Press, 1991.

Cott, Nancy F. The Bonds of Womanhood: “Woman's Sphere” in New England, 1780-1835. Yale University Press, 1977.

Davis, Gayle R. 1987. “Women's Frontier Diaries: Writing for Good Reason.” Women's Studies 14, no. 1(1987): 5. doi:10.1080/00497878.1987.9978682.

Douglas, Ann. The Feminization of American Culture. New York: Farrar, Straus, and Giroux, 1977.

Faragher, John Mack. Sugar Creek: Life on the Illinois Prairie. Yale University Press, 1986.

Fellman, Anita Clair. Little House Long Shadow: Laura Ingalls Wilder's Impact on American Culture. Columbia: University of Missouri Press, 2008. In Lauters, Amy Mattson. Review of Laura Ingalls Wilder and Rose Wilder Lane: Authorship, Place, Time and Culture, and: Little House 
Long Shadow: Laura Ingalls Wilder's Impact on American Culture, American Studies 50, no. 1 (2009): 213-215. doi:10.1353/ams.2011.0039.

Gordon, Beverly. "Meanings in Mid-Nineteenth Century Dress: Images from New England Women's Writings." Clothing and Textiles Research Journal 10, no. 3 (March 1992): 44-53.

Grandin, Greg. The End of the Myth: From the Frontier to the Border Wall in the Mind of America. New York: Metropolitan Books, 2019.

Halttunen, Karen. Confidence Men and Painted Women: A Study of Middle-Class Culture in America, 1830-1870. Yale University Press, 1982.

Handy-Marchello, Barbara. Women of the Northern Plains: Gender and Settlement on the Homestead Frontier, 1870-1930. Minnesota Historical Society Press, 2005.

Johnston, Carolyn Ross. Cherokee Women in Crisis: Trail of Tears, Civil War, and Allotment, 18381907. Tuscaloosa, University of Alabama Press, 2003.

Keck, Michaela. Deliberately Out of Bounds : Women's Work on Classical Myth in Nineteenth-Century American Fiction. Heidelberg: Universitätsverlag Winter, 2017. Accessed March 2, 2021. ProQuest Ebook Central - Reader

Kelley, Mary. At War With Herself: Harriet Beecher Stowe as Woman in Conflict within the Home. In Mary Kelley, ed. Woman's Being, Woman's Place: Female Identity and Vocation in American History. (Boston, MA: G.K. Hall\& Co., 1979), 201-219.

Ketcham, Sallie. Laura Ingalls Wilder: American Writer on the Prairie. New York: Routledge, 2015.

Lawrence, Deborah. Writing the Trail: Five Women's Frontier Narratives. Iowa City: University of Iowa Press, 2006.

Lee, L.L. and Lewis, Merrill. Women, Women Writers, and the West. Troy, NY: The Whitston Publishing Company, 1979.

Louw, Pat. "Contested Spaces in Laura Ingalls Wilder's Little House in the Big Woods and Little House on the Prairie." Mousaion 29, no. 3 (2011): 166-178.

Lystra, Karen. Searching the Heart: Women, Men, and Romantic Love in Nineteenth-Century America. New York: Oxford University Press, 1989.

Mahoney, Timothy R. Provincial Lives: Middle-Class Experience in the Antebellum Middle West. New York: Cambridge University Press, 1999.

Marx, Leo. The Machine in the Garden: Technology and the Pastoral Ideal in America. New York: Oxford University Press, 1964. 
Matt, Susan J. Homesickness: An American History. New York: Oxford University Press, 2011.

McDannell, Colleen. The Christian Home in Victorian America, 1840-1900. Bloomington: Indiana University Press, 1986.

Mielke, Laura L. "Sentiment and Space in Lydia Maria Child's Native American Writings, 1824-1870." Legacy 21, no. 2 (2004): 172-192. doi:10.1353/leg.2004.0034.

Nash Smith, Henry. Virgin Land: The American West as Symbol and Myth. Cambridge: Harvard University Press, 1950.

Nelson, Elizabeth White. Market Sentiments: Middle-Class Culture in Nineteenth-Century America. Washington, D.C.: Smithsonian Books, 2004.

Nelson, Paula M. "The Significance of the Frontier in American Historiography: A Review Essay." Annals of Iowa 50, no. 5 (1990): 531-40. https://search-ebscohostcom.libproxy.lib.ilstu.edu/login.aspx?direct=true $\& \mathrm{db}=\mathrm{ahl} \& \mathrm{AN}=51865484 \&$ site $=$ eds$\underline{\text { live } \& \text { scope }=}=$ site.

Neth, Mary. Preserving the Family Farm: Women, Community, and the Foundations of Agribusiness in the Midwest, 1900-1940. Johns Hopkins University Press, 1995.

Riley, Glenda. Confronting Race: Women and Indians on the Frontier, 1815-1915. Albuquerque: University of New Mexico Press, 2004.

Riley, Glenda. The Female Frontier: A Comparative View of Women on the Prairie and the Plains. University Press of Kansas, 1988.

Rose, Anne C. Voices of the Marketplace: American Thought and Culture, 1830-1860. New York: Twayne, 1995.

Rugh, Susan Sessions. Our Common Country: Family Farming, Culture, and Community in the Nineteenth-Century Midwest. Bloomington: University of Indiana Press, 2001.

Ryan, Mary P. Cradle of the Middle Class: The Family in Oneida County, New York, 1780-1865. New York: Cambridge University Press, 1981.

Ryan, Melissa. "Republican Mothers and Indian Wives: Lydia Maria Child's Indian Stories." ESQ: A Journal of the American Renaissance 56, no. 1 (2010): 33-70. doi:10.1353/esq.0.0046.

Slotkin, Richard. Regeneration Through Violence: The Mythology of the American Frontier, 1600-1860. Norman: University of Oklahoma Press, 1973.

Smith-Rosenberg, Carroll. Disorderly Conduct: Visions of Gender in Victorian America. New York: Oxford University Press, 1985. 
Stewart, Polly. In Her Own Words: Women's Frontier Friendships in Letters, Diaries, and Reminiscences. Logan: Utah State University Press, 2000. https://search-ebscohostcom.libproxy.lib.ilstu.edu/login.aspx?direct=true \&db=edspmu\&AN=edspmu.MUSE9780874214 $\underline{567.22 \& \text { site }=\text { eds-live \&scope }=\text { site. }}$.

Storrs, Kera B. "Frontier Respectability to Gilded Age Splendor: Women and Consumerism in the Cultural Development of Bloomington, Illinois, 1839-1900." Order No. 1590170, Illinois State University, 2015. http://libproxy.lib.ilstu.edu/login?url=https://www-proquestcom.libproxy.lib.ilstu.edu/dissertations-theses/frontier-respectability-gilded-age-splendorwomen/docview/1692610113/se-2?accountid=11578.

Stratton, Joanna L. Pioneer Women: Voices From the Kansas Frontier. New York: Simon \& Schuster, Inc., 1981.

Theriot, Nancy M. Mothers and Daughters in Nineteenth-Century America: The Biosocial Construction of Femininity. Lexington: The University Press of Kentucky, 2015. https://search-ebscohostcom.libproxy.lib.ilstu.edu/login.aspx?direct $=$ true $\& d b=$ nlebk\&AN $=938326 \&$ site $=$ eds$\underline{\text { live\&scope }=\text { site. }}$.

Tompkins, Jane. Sensational Designs: The Cultural Work of American Fiction, 1790-1860. New York: Oxford University Press, 1985.

Troutman, Phillip. Correspondences in Black and White: Sentiment and the Slave Market Revolution. In Baptist, Edward. E. and Camp, Stephanie, eds. New Studies in the History of American Slavery. Athens: The University of Georgia Press, 2006.

Ulrich, Laurel Thatcher. A Midwife's Tale: The Life of Martha Ballard, Based on Her Diary 1785-1812. New York: Vintage Books, 1990.

Ulrich, Laurel Thatcher. The Age of Homespun: Objects and Stories in the Creation of an American Myth. New York: Vintage books, 2002.

Welter, Barbara. "The Cult of True Womanhood: 1820-1860." American Quarterly 18, no. 2 (1966): 151-74. doi:10.2307/2711179.

White, Richard and Limerick, Patricia Nelson. The Frontier in American Culture. Los Angeles: University of California Press, 1994.

Williams, Deborah Lindsay. Review of Constructing the Little House: Gender, Culture, and Laura Ingalls Wilder. Studies in American Fiction 27, no. 2 (1999): 251-253. doi:10.1353/saf.1999.0009. 